\title{
SUMMARY OF HYDROLOGY OF THE REGIONAL AQUIFER SYSTEMS, \\ GULF COASTAL PLAIN, SOUTH-CENTRAL UNITED STATES
}

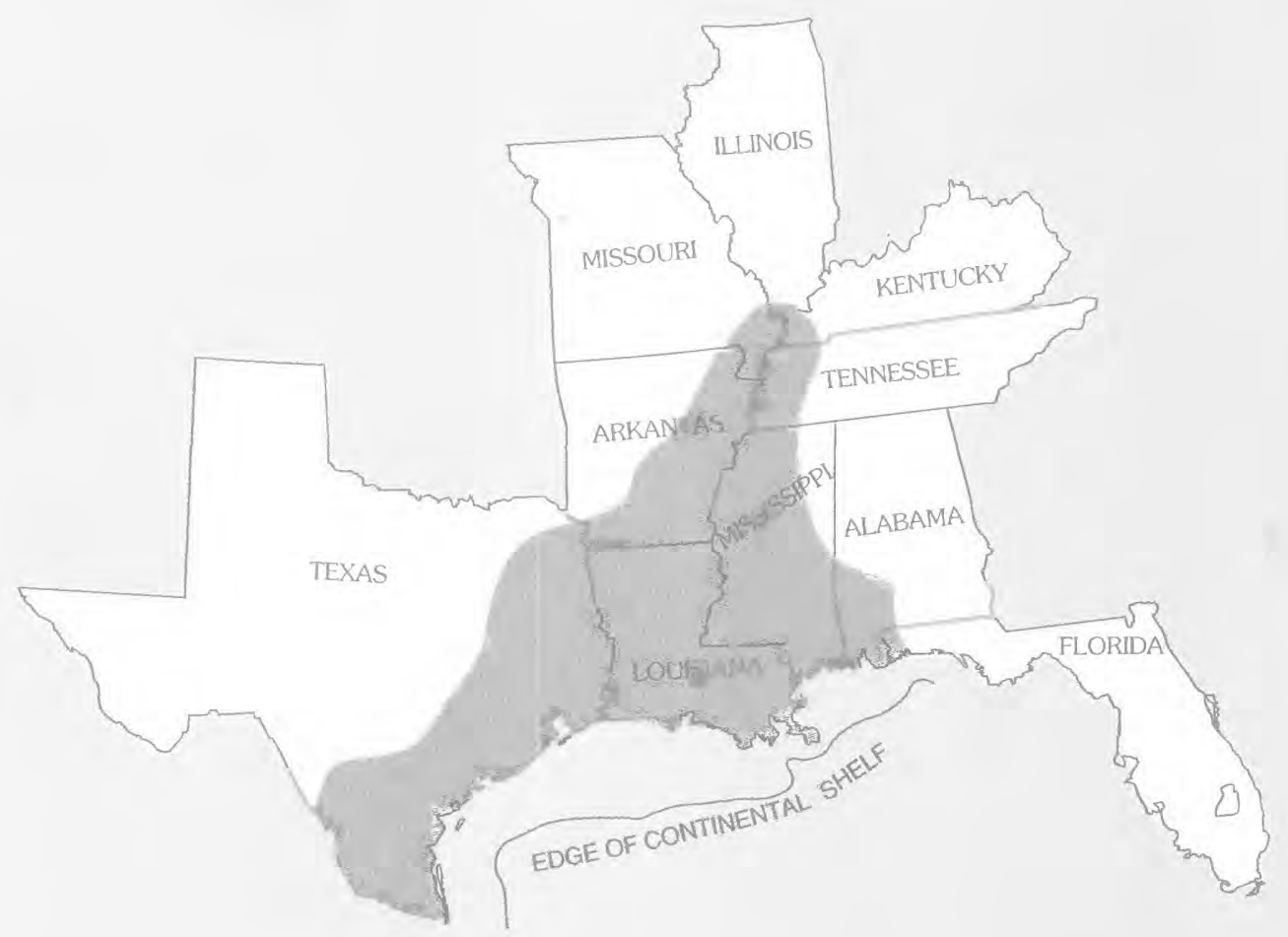




\section{Availability of Publications of the U.S. Geological Survey}

Order U.S. Geological Survey (USGS) publications from the offices listed below. Detailed ordering instructions, along with prices of the last offerings, are given in the current-year issues of the catalog "New Publications of the U.S. Geological Survey."

\section{Books, Maps, and Other Publications}

\section{By Mail}

Books, maps, and other publications are available by mail from-

USGS Information Services

Box 25286, Federal Center

Denver, CO 80225

Publications include Professional Papers, Bulletins, WaterSupply Papers, Techniques of Water-Resources Investigations, Circulars. Fact Sheets, publications of general interest, single copies of permanent USGS catalogs, and topographic and thematic maps.

\section{Over the Counter}

Books, maps, and other publications of the U.S. Geological Survey are available over the counter at the following USGS Earth Science Information Centers (ESIC's), all of which are authorized agents of the Superintendent of Documents:

- Anchorage, Alaska- Rm. 101, 4230 University Dr.

- Denver, Colorado-Bldg. 810, Federal Center

- Menlo Park, California-Rm. 3128, Bldg. 3. 345 Middlefield Rd.

- Reston, Virginia-Rm. 1C402, USGS National Center, 12201 Sunrise Valley Dr.

- Salt Lake City, Utah-2222 West, 2300 South (books and maps available for inspection only)

- Spokane. Washington-Rm. 135, U.S. Post Office Building, 904 West Riverside Ave.

- Washington, D.C.-Rm. 2650, Main Interior Bldg., 18 th and C Sts., NW

Maps only may be purchased over the counter at the following USGS office:

- Rolla, Missouri-1400 Independence Rd.

\section{Electronically}

Some USGS publications, including the catalog "New Publications of the U.S. Geological Survey" are also available electronically on the USGS's World Wide Web home page at http://www.usgs.gov

\section{Preliminary Determination of Epicenters}

Subscriptions to the periodical "Preliminary Determination of Epicenters" can be obtained only from the Superintendent of
Documents. Check or money order must be payable to the Superintendent of Documents. Order by mail from-

\author{
Superintendent of Documents \\ Government Printing Office \\ Washington, DC 20402
}

\section{Information Periodicals}

Many Information Periodicals products are available through the systems or formats listed below:

\section{Printed Products}

Printed copies of the Minerals Yearbook and the Mineral Commodity Summaries can be ordered from the Superintendent of Documents. Government Printing Office (address above). Printed copies of Metal Industry Indicators and Mineral Industry Surveys can be ordered from the Center for Disease Control and Prevention, National Institute for Occupational Safety and Health, Pittsburgh Research Center, P.O. Box 18070, Pittsburgh, PA 15236-0070.

\section{Mines FaxBack: Return fax service}

1. Use the touch-tone handset attached to your fax machine's telephone jack. (ISDN [digital] telephones cannot be used with fax machines.)

2. Dial (703) 648-4999.

3. Listen to the menu options and punch in the number of your selection, using the touch-tone telephone.

4. After completing your selection, press the start button on your fax machine

\section{CD-ROM}

A disc containing chapters of the Minerals Yearbook (199395), the Mineral Commodity Summaries (1995-97), a statistical compendium (1970-90), and other publications is updated three times a year and sold by the Superintendent of Documents, Government Printing Office (address above).

\section{World Wide Web}

Minerals information is available electronically at http://minerals.er.usgs.gov/minerals/

\section{Subscription to the catalog "New Publications of the U.S. Geological Survey"}

Those wishing to be placed on a free subscription list for the catalog "New Publications of the U.S. Geological Survey" should write to-

U.S. Geological Survey

903 National Center

Reston, VA 20192 
Summary of Hydrology of the

Regional Aquifer Systems, Gulf Coastal Plain, South-Central United States

By HAYES F. GRUBB

REGIONAL AQUIFER-SYSTEM ANALYSIS-GULF COASTAL PLAIN

U.S. GEOLOGICAL SURVEY PROFESSIONAL PAPER 1416-A 


\title{
U.S. DEPARTMENT OF THE INTERIOR \\ BRUCE BABBITT, Secretary
}

\author{
U.S. GEOLOGICAL SURVEY \\ Charles G. Groat, Director
}

Any use of trade, product, or firm names in this publication is for descriptive purposes only and does not imply endorsement by the U.S. Government

Library of Congress Cataloging-in-Publication Data

Grubb, Hayes F.

Summary of hydrology of the regional aquifer systems, Gulf coastal plain, south-central United States / by Hayes F. Grubb.

p. cm. - (Regional aquifer-system analysis-Gulf coastal plain) (U.S. Geological Survey professional paper ; 1416-A)

Includes bibliographical references.

1. Aquifers-Gulf Coast Region (U.S.) I. Title. II. Series. III. Series: U.S. Geological Survey professional paper; 1416-A.

GB1199.3.G85G78 1997

97-38786

$551.49^{\prime} 0976-\mathrm{dc} 21$

For sale by the U.S. Geological Survey Map Distribution

Box 25286, Mail Stop 306, Denver Federal Center

Denver, CO 80225-0286 


\section{FOREWORD}

\section{THE REGIONAL AQUIFER-SYSTEM ANALYSIS PROGRAM}

The Regional Aquifer-System Analysis (RASA) Program was started in 1978 following a congressional mandate to develop quantitative appraisals of the major groundwater systems of the United States. The RASA Program represents a systematic effort to study a number of the Nation's most important aquifer systems, which in aggregate underlie much of the country and which represent an important component of the Nation's total water supply. In general, the boundaries of these studies are identified by the hydrologic extent of each system and accordingly transcend the political subdivisions to which investigations have often arbitrarily been limited in the past. The broad objective for each study is to assemble geologic, hydrologic, and geochemical information, to analyze and develop an understanding of the system, and to develop predictive capabilities that will contribute to the effective management of the system. The use of computer simulation is an important element of the RASA studies, both to develop an understanding of the natural, undisturbed hydrologic system and the changes brought about in it by human activities, and to provide a means of predicting the regional effects of future pumping or other stresses.

The final interpretive results of the RASA Program are presented in a series of U.S. Geological Survey Professional Papers that describe the geology, hydrology, and geochemistry of each regional aquifer system. Each study within the RASA Program is assigned a single Professional Paper number, and where the volume of interpretive material warrants, separate topical chapters that consider the principal elements of the investigation may be published. The series of RASA interpretive reports begins with Professional Paper 1400 and thereafter will continue in numerical sequence as the interpretive products of subsequent studies become available.

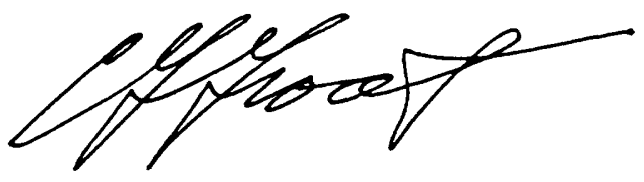

Charles G. Groat

Director 



\section{CONTENTS}

\begin{tabular}{|c|c|c|}
\hline Page & & Page \\
\hline AlII & History of ground-water development-Continued & \\
\hline A1 & Southwestern Louisiana .. & A33 \\
\hline 1 & Winter Garden..... & 35 \\
\hline 3 & Regional ground-water flow ............... & 35 \\
\hline 5 & 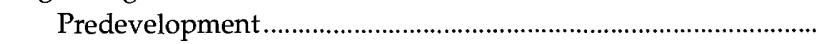 & 36 \\
\hline 6 & Recharge and discharge ................. & 36 \\
\hline 6 & 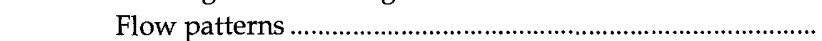 & 37 \\
\hline 10 & Permeable zone B & 38 \\
\hline 12 & Middle Claiborne aquifer.......... & 43 \\
\hline 12 & 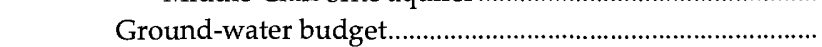 & 43 \\
\hline 18 & Effects of water density .................... & 44 \\
\hline & 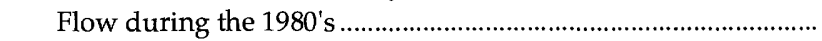 & 45 \\
\hline & 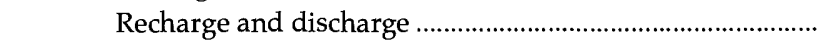 & 45 \\
\hline & Flow patterns & 46 \\
\hline & Permeable zone B & 46 \\
\hline & 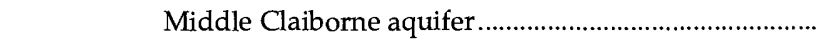 & 46 \\
\hline 28 & 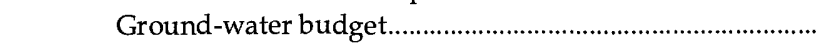 & 51 \\
\hline 29 & 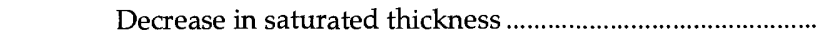 & 52 \\
\hline$x$ & Land subsidence & 53 \\
\hline 31 & 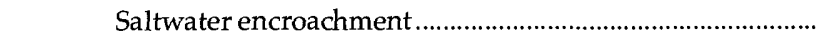 & 54 \\
\hline 32 & 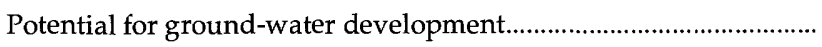 & 54 \\
\hline 3 & References .... & 55 \\
\hline
\end{tabular}

\section{ILLUSTRATIONS}

FIGURES 1-7. Maps showing:

1. Location of Gulf Coast Regional Aquifer-System Analysis study area and adjacent Regional Aquifer-System Analysis study areas.

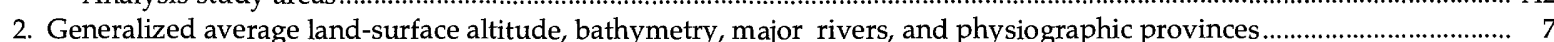

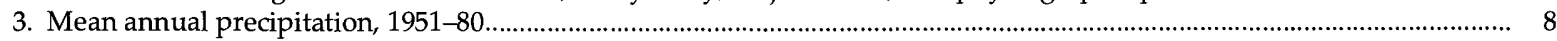

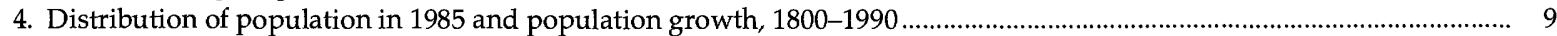

5. Generalized geology and structural features, Gulf Coastal Plain, south-central United States............................................. 11

6. Generalized outcrop of aquifer systems, intervening regional confining units, and designated geographic areas .............. 13

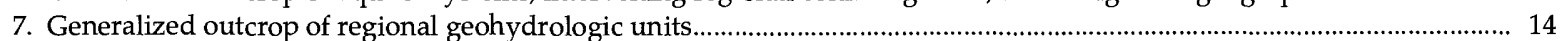

8. Graph showing areal extent of aquifers and permeable zones ........................................................................................... 16

9. Idealized section from boundary of study area in Zavala County, Texas, southeastward through Kleberg County, Texas,

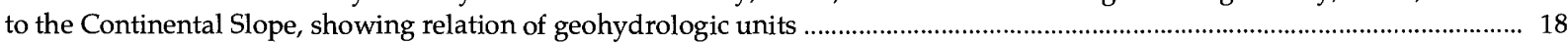

10. Map showing thickness of permeable zone B (lower Pleistocene-upper Pliocene deposits), coastal lowlands aquifer system .......... 19

11. Map showing thickness of the middle Claiborne aquifer, Texas coastal uplands and Mississippi embayment aquifer systems....... 21

12. Idealized section from near northern boundary of study area in Mississippi County, Missouri, to Iberville Parish, Louisiana, showing relation of geohydrologic units.

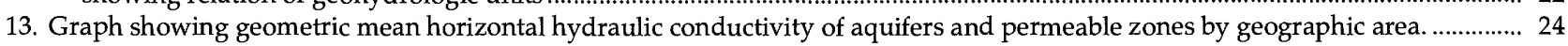

14. Map showing dominant water types in permeable zone B (lower Pleistocene-upper Pliocene deposits), coastal lowlands aquifer system

15. Map showing dominant water types in the middle Claiborne aquifer, Texas coastal uplands and Mississippi embayment aquifer systems 
16-24. Graphs showing:

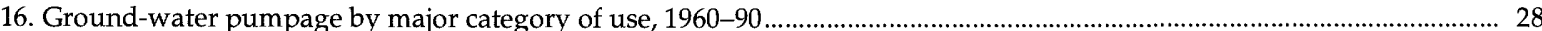

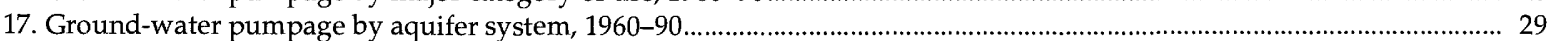

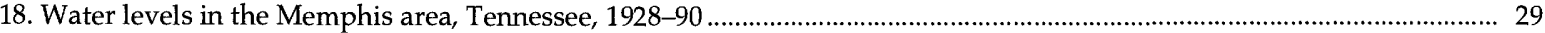

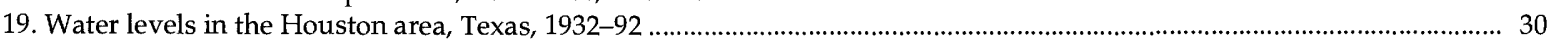

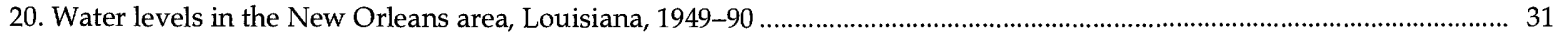

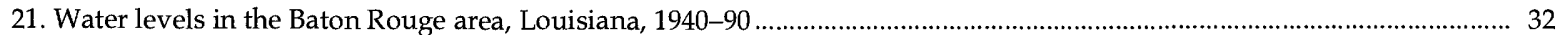

22. Water levels in the Mississippi Alluvial Plain, 1929-87 .............................................................................................. 33

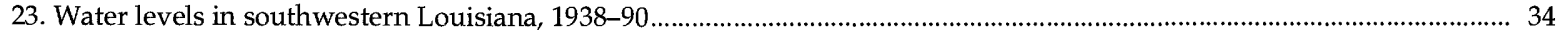

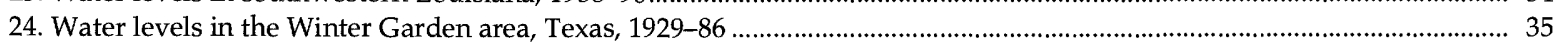

25-27. Maps showing predevelopment regional recharge and discharge areas, and thickness:

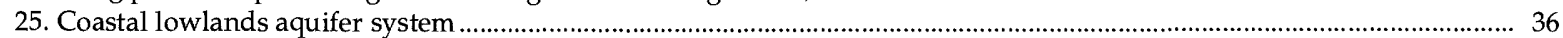

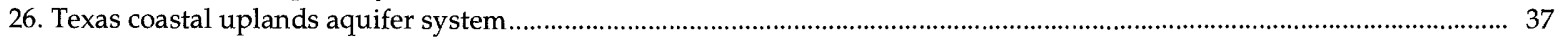

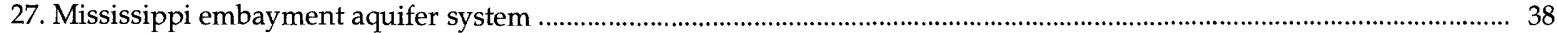

28-31. Maps showing direction and relative magnitude of simulated predevelopment horizontal flow, area where vertical flow relative to base of permeable zone was downward, altitude and configuration of top, depth-averaged dissolved-solids concentration, and location of salt domes that penetrate base of:

28. Permeable zone A, coastal lowlands aquifer system, and the Mississippi River Valley alluvial aquifer............................. 39

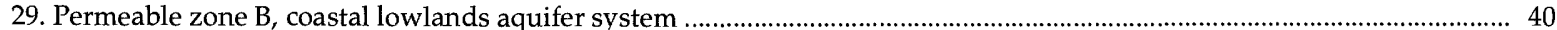

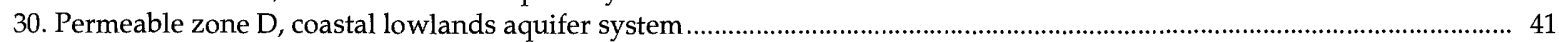

31. Middle Claiborne aquifer, Texas coastal uplands and Mississippi embayment aquifer systems .........................................42

32. Diagram showing simulated predevelopment ground-water budget from the regional-scale model ............................................... 44

33-36. Maps showing regionalized horizontal hydraulic conductivity, areas where simulated vertical flow relative

to base of unit reversed direction from upward to downward (predevelopment to 1987), and 1987 simulated

direction and relative magnitude of horizontal flow in permeable zones and aquifers:

33. Permeable zone A, coastal lowlands aquifer system, and the Mississippi River Valley alluvial aquifer.............................. 47

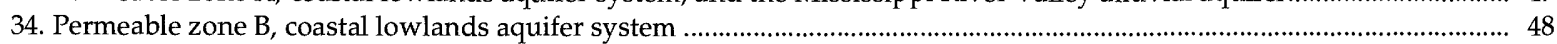

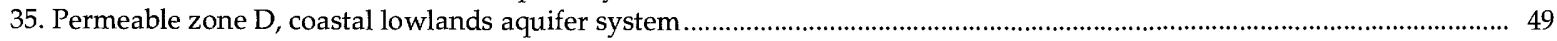

36. Middle Claiborne aquifer, Texas coastal uplands and Mississippi embayment aquifer systems ........................................ 50

37-38. Diagrams showing:

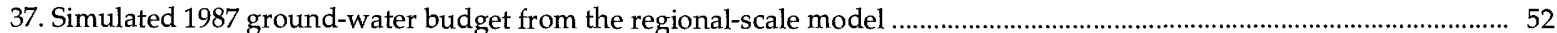

38. Simulated ground-water budget for the Mississippi River Valley alluvial aquifer, predevelopment through $1987 \ldots \ldots \ldots \ldots . . .53$

\section{TABLES}

TABLE 1. Geologic units and geohydrologic units of the gulf coast aquifer systems ...............................................................................

2. Summary of thickness and sand percentage of aquifers and permeable zones.............................................................................. 17 


\section{CONVERSION FACTORS, VERTICAL DATUM, AND ABBREVIATED WATER-QUALITY UNITS}

For readers who prefer to use metric units, conversion factors for terms used in this report are listed below:

\begin{tabular}{lcl}
\hline Multiply & By & To obtain \\
\hline & & millimeters \\
inch & 25.4 & millimeters per year \\
inch per year (inch $/ \mathrm{yr})$ & 25.4 & meter \\
foot $(\mathrm{ft})$ & 0.3048 & meter per day \\
foot per day $(\mathrm{ft} / \mathrm{d})$ & 0.3048 & meter per year \\
foot per year $(\mathrm{ft} / \mathrm{yr})$ & 0.3048 & meter squared per day \\
foot squared per day $\left(\mathrm{ft}^{2} / \mathrm{d}\right)$ & 0.0929 & kilometer \\
mile $(\mathrm{mi})$ & 1.609 & square kilometer \\
square mile $\left(\mathrm{mi}^{2}\right)$ & 2.590 & cubic meter per second \\
million gallons per day $(\mathrm{Mgal} / \mathrm{d})$ & 0.04381 & \\
\hline
\end{tabular}

Sea level: In this report, "sea level" refers to the National Geodetic Vertical Datum of 1929 (NGVD of 1929)-a geodetic datum derived from a general adjustment of the first-order level nets of the United States and Canada, formerly called Sea Level Datum of 1929.

Chemical concentration and water density are given in metric units. Chemical concentration is given in milligrams per liter (mg/L). Water density is given in grams per cubic centimeter $\left(\mathrm{g} / \mathrm{cm}^{3}\right)$. Water temperature is given in degrees Celsius $\left({ }^{\circ} \mathrm{C}\right)$, which can be converted to degrees Fahrenheit $\left({ }^{\circ} \mathrm{F}\right)$ by the following equation:

$$
{ }^{\circ} \mathrm{F}=1.8\left({ }^{\circ} \mathrm{C}\right)+32
$$





\title{
SUMMARY OF HYDROLOGY OF THE REGIONAL AQUIFER SYSTEMS, GULF COASTAL PLAIN, SOUTH-CENTRAL UNITED STATES
}

\author{
BY HAYES F. GRUBB
}

\begin{abstract}
The gulf coast regional aquifer system consists of regional aquifers in sediments of mostly Cenozoic age in an area of about 230,000 square miles in the Gulf Coastal Plain of Alabama, Arkansas, Florida, Illinois, Kentucky, Louisiana, Mississippi, Missouri, Tennessee, and Texas and an additional 60,000 square miles offshore. Three aquifer systems (the Mississippi embayment, Texas coastal uplands, and coastal lowlands) have been divided into six regional aquifers and five permeable zones. The aquifers and permeable zones range in areal extent from about 32,000 to 170,000 square miles and typically thicken from their outcrop area toward the Gulf of Mexico or toward the axes of major embayments. The average thickness of aquifers and permeable zones ranges from 140 to 2,010 feet. Horizontal hydraulic conductivity of aquifers and permeable zones ranges from about 20 to 315 feet per day.

Water in the gulf coast aquifer systems is generally fresh [less than 1,000 milligrams per liter ( $\mathrm{mg} / \mathrm{L}$ ) dissolved solids] in and near outcrop areas of the permeable zones and aquifers. Dissolved-solids concentrations in water from all aquifers and permeable zones generally increase toward the Gulf of Mexico and toward principal discharge areas; concentrations typically increase from 10,000 to $35,000 \mathrm{mg} / \mathrm{L}$ over distances of 10 to 40 miles. In the deeper parts of the permeable zones and aquifers, the dissolved-solids concentrations typically exceed that of seawater by as much as a factor of 2 . The dominant water type in and near aquifer outcrop areas typically is calcium bicarbonate or a mixture of calcium bicarbonate and sodium bicarbonate. The water type is dominantly sodium bicarbonate in middip areas of the aquifers. The dominant water type typically is sodium chloride near the downdip limit of the aquifers and permeable zones. A variety of geochemical processes contribute to the water chemistry in the gulf coast aquifer systems. The major postulated processes are (1) leaching of soluble salts from the unsaturated zone; (2) alteration of albite; (3) cation exchange; (4) mixing of water by the vertical flow of water from underlying units; and (5) the dissolution of halite from salt diapirs.

Simulation of regional ground-water flow (excludes local flow of several miles or less) indicates that regional ground-water flow prior to withdrawal of ground water (predevelopment) generally was from areas of high water-level altitude toward major rivers or broad extensive areas at low land-surface altitude. Of a total 2,900 million gallons per day $(\mathrm{Mgal} / \mathrm{d})$ of simulated predevelopment recharge, the most to a single aquifer was to the Mississippi River Valley alluvial aquifer $(830 \mathrm{Mgal} / \mathrm{d}$ ) and the least was to the lower Wilcox aquifer (14 Mgal/d). The largest discharge was also to the Mississippi River Valley alluvial aquifer (about 1,200 Mgal/d) and the smallest was also to the lower Wilcox aquifer (12 Mgal/d). Net vertical flows ranged from less than $1 \mathrm{Mgal} / \mathrm{d}$ between the lower Wilcox aquifer and the middle Wilcox aquifer to about $300 \mathrm{Mgal} / \mathrm{d}$ between permeable zone $\mathrm{B}$ and permeable zone $\mathrm{A}$.

More than 90 years of large ground-water withdrawals (about $10,000 \mathrm{Mgal} / \mathrm{d}$ during 1980) had lowered water levels and greatly altered regional ground-water flow patterns by the 1980's. Many predevelopment regional discharge areas became regional recharge areas.
\end{abstract}

Regional recharge increased from about $2,900 \mathrm{Mgal} / \mathrm{d}$ under simulated predevelopment conditions to about $9,600 \mathrm{Mgal} / \mathrm{d}$ during 1985 , and discharge decreased from about 2,900 $\mathrm{Mgal} / \mathrm{d}$ to about 1,100 Mgal/d during the same period. Horizontal flow directions have been altered; flow lines that extended from the shoreline toward the edge of the Continental Shelf prior to ground-water withdrawal currently (1985) converge toward pumping centers located in coastal areas of Texas and Louisiana. Likewise, vertical flow direction reversed at many locations such as at Houston, Texas, and in the vicinity of Memphis, Tennessee. Long-term decreases in saturated thickness have resulted from the withdrawal of ground water in the lower Claiborne-upper Wilcox aquifer in southern Texas and in the Mississippi River Valley alluvial aquifer in eastern and central Arkansas. Saturated thickness decreased at the rate of 1.5 feet per year in southern Texas during the period 1965-85 and at the rate of about 2 feet per year at some locations in eastern and central Arkansas during the 1980's. Other local effects of ground-water withdrawal are land subsidence-as much as 10 feet near Houston, Texas - and saltwater encroachment in southwestern Louisiana, where chloride concentration increased at the rate of 5 to 15 $\mathrm{mg} / \mathrm{L}$ per year during the period 1963-83.

There is potential for further development of ground-water supplies in the Gulf Coastal Plain because of the abundance of water in streams, lakes, and swamps and the generally good hydraulic connection between the water table and underlying water-yielding units. The aquifer systems have the potential to support additional withdrawals of as much as $10,000 \mathrm{Mgal} / \mathrm{d}$ if pumping centers are carefully located. The most favorable conditions for further development of groundwater supplies are generally in the upper permeable zones and aquifers, and the potential for development typically increases from west to east.

\section{INTRODUCTION}

The Gulf Coast Regional Aquifer-System Analysis (Gulf Coast RASA), a study of ground water in Gulf Coastal Plain sediments in the south-central United States, is part of the Regional Aquifer-System Analysis Program of the U.S. Geological Survey (see Foreword). The program began in 1978 and was designed to provide a regional understanding and assessment of the Nation's ground-water resources (Bennett, 1979). A detailed discussion of the background leading to the initiation of the RASA Program is given by Sun (1986). Four other RASA studies have been conducted in areas adjacent to the Gulf Coast RASA study area (fig. 1). 


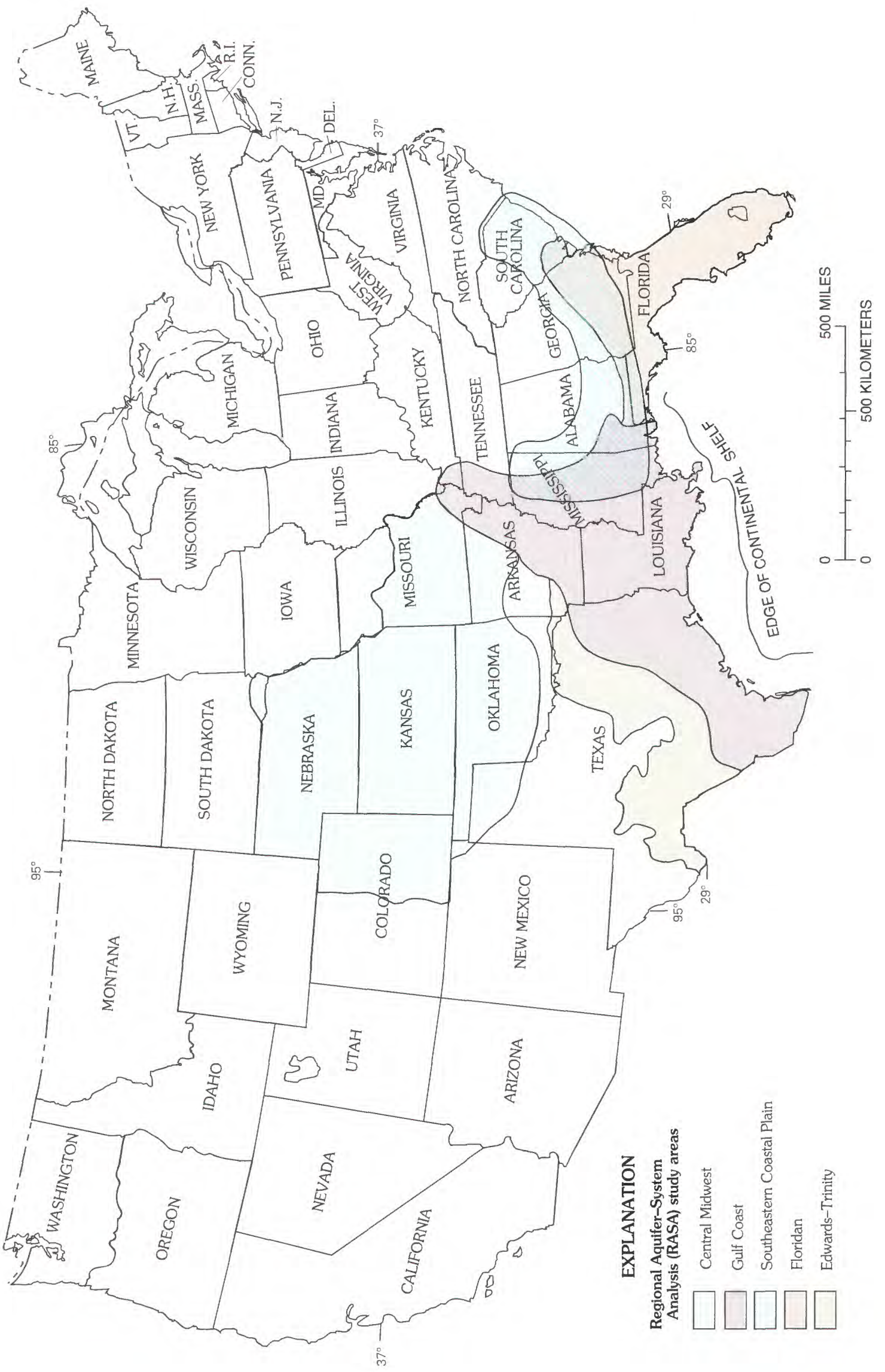


The RASA studies in areas adjacent to the Gulf Coast RASA study are the Edwards-Trinity, Central Midwest, Southeastern Coastal Plain, and Floridan (fig. 1). The Edwards-Trinity aquifer system lies to the northwest of the Gulf Coast RASA study area in Texas and adjacent parts of Oklahoma and Arkansas. The Edwards-Trinity aquifer system consists of indurated limestones and sandstones of Cretaceous age and is separated from aquifer systems that are the subject of this study by massive clays and limestones of minimal permeability. The Ozark aquifer of the Central Midwest RASA consists of limestones, dolostones, and sandstones of Late Cambrian through Devonian age. The Ozark aquifer is exposed at the land surface to the northwest of the Gulf Coastal Plain in northern Arkansas and southern Missouri and dips beneath Gulf Coastal Plain sediments in southeastern Missouri and northeastern Arkansas. The massive clays that separate the two aquifer systems become thin near the northwestern boundary of the Gulf Coastal Plain, and the potential exists for groundwater to flow upward from the Ozark aquifer to Gulf Coastal Plain sediments. During the course of this study, ground water was found to flow upward from the Ozark aquifer in substantial amounts only in a localized area near the northwestern boundary of the Gulf Coastal Plain. The Southeastern Coastal Plain aquifer system mostly consists of unconsolidated sands of Cretaceous and Tertiary age to the east of the Gulf Coastal Plain. The aquifers of Cretaceous age dip beneath the sediments that constitute the Gulf Coast RASA in Mississippi, southwestern Alabama, and Florida and are separated from the overlying aquifers by massive clays of minimal permeability; thus, there is little potential for ground water to flow between the two systems. The Floridan aquifer system, which mostly consists of permeable carbonate rocks of Tertiary age, lies largely to the east of the Gulf Coast RASA study area. However, in southwestern Alabama and western Florida, the rocks of the Floridan aquifer undergo a facies change from carbonate rock to marine clay, which forms a regional confining unit throughout most of the Gulf Coast RASA study area.

Large quantities of water are withdrawn from the streams and aquifers of the Gulf Coastal Plain. The quantity of ground water withdrawn during 1985 was about one-half the quantity of surface water withdrawn. Rates of ground-water withdrawal have increased unevenly throughout the years as the demand for public supply, industry, and irrigation (the three largest uses in the study area) generally has grown. Ground-water withdrawals have caused lowering of water levels in and near pumping centers, induced the movement of the fresh-saltwater interface into parts of aquifers that previously contained freshwater, accelerated land subsidence due to the compaction of interbedded clays within the aquifers, and increased the lift for pumps as a result of the lower water levels. Much work has been done to study these effects and to evaluate the ground-water resources in an effort to provide a rational guide for the management and development of the ground-water resources of the Gulf Coastal Plain. Following is a short summary of earlier studies and those that were done as part of the Gulf Coast RASA.

\section{PREVIOUS INVESTIGATIONS}

The aquifers of the Gulf Coastal Plain of the southcentral United States have been the subject of study for the past 90 years. The importance of the groundwater resource was recognized early during this period, and R.T. Hill noted that the Coastal Plain of Texas, "*** constitutes one of the most productive artesian regions of America, if not in the world $* * * * "$ (Hill, 1901, p. 398). Throughout the years since 1901, many types of problems related to the ground-water resource have been studied and various types of reports have been published. By the middle of the second decade of the 20th century, reports had been published describing the ground-water resources in Coastal Plain sediments for every State in the study area (Harris, 1904; Crider and Johnson, 1906; Glenn, 1906; Veatch, 1906; Shepard, 1907; Smith, 1907; Taylor, 1907; Matson and Sanford, 1913; and Stephenson and Crider, 1916). These reports are characterized by extensive tables of data on wells, surficial geologic maps, and general discussions of the occurrence of ground water. As the last of these studies was completed, attention was directed to more detailed studies of smaller areas and specific problems. In a report on La Salle and McMullen Counties in Texas (county and city locations shown in fig. 28), the first detailed county study within the Gulf Coast RASA study area, Deussen and Dole (1916) noted that close spacing of wells resulted in interference among them.

A more detailed evaluation of the ground-water resources was typical of many studies that began to be published in the 1930's for individual Texas counties (Lonsdale, 1935; Livingston and Bridges, 1936; Sayre, 1937; and Lonsdale and Day, 1937). Thus began a process in which detailed studies of the ground-water resources of counties in Texas were released over a period of several decades, examples of which are reports by Follett (1947), Rasmussen (1947), Winslow (1950), Petitt (1955), Mason, (1960), Broom (1965), Shafer (1970), Follett (1974), and Rettman (1984). Detailed county studies of ground water in other States began 
later than those in Texas, but by the end of the 1970's, reports had been released for most counties in the study area. Examples of reports for Louisiana parishes are Maher (1941), U.S. Geological Survey (1951), Poole (1961), Marie (1971), Case (1979), and Tomaszewski (1988). Examples of reports for other States are Mississippi, Callahan and others (1963); Wasson and others (1965); Taylor and Thomson (1971); Dalsin and Bettandorff (1976); Spiers and Dalsin (1979); Arkansas, Engler and others (1945); Hewitt and others (1949); Counts (1957); Albin (1964); Plebuch and Hines (1967); Lamonds and others (1969); Ludwig (1972); Alabama, Toulmin and others (1951); Newton and others (1961); Reed and McCain (1971); Davis and others (1980); and Tennessee, Wilson and Criner (1969); Parks and others (1985). In Kentucky, detailed ground-water studies were released as a series of map reports of each 7.5minute quadrangle, examples of which are MacCary (1964), Davis (1965), MacCary and Davis (1966), Hansen (1967), and Lambert (1968). As development of groundwater supplies increased, so did the interest in areas smaller than counties and in problems usually associated with large ground-water withdrawals.

A report on the water supply of Memphis, Tenn. (Wells, 1932), was one of the earliest attempts to relate cause and effect (that is, pumping rates to water-level declines in wells). The report included a profile of the observed pressure surface and location of pumping from the lower Wilcox aquifer at four different times. In a study of the Houston District, Texas, White and others (1944) presented drawdown curves at increasing distances from a pumping well, after 1, 2, and 10 years of pumping. These curves were based on the results of aquifer tests, assumed pumping rates, and the Theis (1935) nonequilibrium formula. Special problems related to ground-water withdrawals, such as saltwater encroachment in the Houston-Galveston area (Winslow, and others, 1957; Jorgensen, 1977) and in the Baton Rouge area (Rollo, 1969), effects of faults on ground-water flow (Whiteman, 1979; Gabrysch 1984), and land subsidence (Winslow and Doyel, 1954; Winslow and Wood, 1959; Gabrysch, 1969, 1977, and 1982; Gabrysch and Bonnet, 1975; Gabrysch and Coplin, 1990; Whiteman, 1980; Ratzlaff, 1982) were documented in many reports. The complexity of ground-water problems increased as the number of wells and volume of water withdrawn increased, thus making it more difficult to clearly relate cause and effect. Consequently, ground-water flow simulation techniques were applied with increasing frequency in an attempt to evaluate the effect of multiple factors on the ground-water resource.

Simulation of ground-water flow in the Gulf Coastal Plain was introduced by Patton (as described in Wood and Gabrysch, 1965) with the application of an analog model in the Houston District, Texas. Subsequently, analog models were used to simulate ground-water flow relative to specific problems at several locations, such as water-level declines in the Sparta Sand in the northern Mississippi embayment (Reed, 1972); streamaquifer interactions in Arkansas (Broom and Reed, 1973); the effects of recharge wells on the potentiometric surface of aquifers in the vicinity of the Houston, Tex., ship channel (Jorgensen, 1973); and declines in the potentiometric surfaces of aquifers in the Houston District, Texas, in response to alternative locations and magnitudes of ground-water withdrawals (Jorgensen, 1975; Jorgensen and Gabrysch, 1974).

Simulation of ground-water flow within the study area continued as digital computer models replaced analog models, and attention continued to be focused on specific problems at various locations. Examples include simulation of water levels in an alluvial aquifer adjacent to a reservoir in eastern Texas (Garza, 1974); simulation of decline in water levels due to widespread ground-water withdrawals in southern Texas (Klemt and others, 1976); simulation of stream-aquifer interactions in Arkansas (Reed and Broom, 1979); simulation of declines in potentiometric surfaces of aquifers and land subsidence in the Houston area, Texas (Meyer and Carr, 1979; Carr and others, 1985); and simulation of water-level rises due to construction of navigation facilities on the Red River in northern Louisiana (Ludwig and Terry, 1980; Rogers, 1983). Simulations were made of water-level declines due to large ground-water withdrawals for northeastern Arkansas (Broom and Lyford, 1981); for the Memphis area, Tennessee (Brahana, 1982); for northwestern Mississippi (Sumner and Wasson, 1984a, 1984b); for the Baton Rouge area, Louisiana (Torak and Whiteman, 1982; Huntzinger and others, 1985; Kuniansky, 1989); and for the Gulf Coastal Plain of Texas (Carr and others, 1985). Simulation of groundwater flow has been used within the study area to evaluate various activities such as the use of piercementtype salt domes for the isolation of radioactive waste in eastern Texas (Fogg and others, 1983); solution mining of uranium in southern Texas (Henry and others, 1982); and open-pit mining of lignite in east-central Texas (Charbeneau and Wright, 1983). Also, simulation of ground-water flow has been used recently to evaluate the potential for the movement of saline water from adjacent aquifers into aquifers with large withdrawals (Groschen, 1985; Trudeau and Buono, 1985).

These problem-oriented studies were conducted with little consideration of the regional ground-water flow system. The regional study of the Mississippi embayment (Cushing and others, 1970; Boswell and others, 1965, 1968; Hosman and others, 1968) and the multi-State study of the Claiborne Group (Payne, 1968, 
1970, 1972, 1975) were comprehensive and largely descriptive, and the summary appraisals of the groundwater resource in major river basins (West and Broadhurst, 1975; Baker and Wall, 1976; Bedinger and Sniegocki, 1976; Zurawski, 1978; Cederstrom and others, 1979; Terry and others, 1979) were qualitative evaluations of the availability of the resource and discussions of various management strategies rather than a quantitative cause-and-effect analysis. All of the studies cited above, plus many more that are not cited, provide a large body of data and interpretive material. Although these data are not uniformly distributed in time or space, they provided a base upon which the Gulf Coast RASA study could build and thus develop an understanding of the regional ground-water flow system.

\section{REGIONAL ANALYSIS OF THE GULF COAST AQUIFER SYSTEMS}

The major objectives of the Gulf Coast RASA study are to delineate the geohydrologic framework, describe the ground-water chemistry, and determine regional flow patterns. A regionally consistent geohydrologic framework was developed, a regional description of ground-water chemistry was made, and ground-water flow models were used to simulate regional flow patterns. The following discussion highlights the efforts involved in meeting the study objectives.

Many interim reports (Sun and Weeks, 1991) were released to describe progress or to document techniques, procedures, and data used during the study. Progress on the study was reported by Grubb (1985, 1986b, 1987, 1992); Wilson and Hosman (1988) described a geophysical well-log data base; Weiss and Williamson (1985) presented a method for vertically subdividing thick sedimentary units; and maps, sections, and diagrams of the geohydrologic framework were constructed by Hosman $(1982,1988)$; Arthur and Taylor (1986); Mesko (1988, 1990); Parks and Carmichael (1989, 1990b, 1990c); Taylor and Arthur (1989); and Whiteman and Martin (1984). Potentiometric surface maps were prepared for several aquifers, some for the first time, by Ackerman (1987a, 1987b, 1989b); Boswell and Arthur (1988); Garza and others (1987); Martin and Whiteman (1985a, 1985b, 1986); Martin and others (1988); and Parks and Carmichael (1990a, 1990b). Williams and Williamson (1989) presented a technique for estimating predevelopment water-table altitudes for regional ground-water studies of the Gulf Coastal Plain.

The areal distribution of dissolved-solids concentrations, major ion concentrations, and primary water types in ground water from the study area were shown by Pettijohn (1988); Pettijohn and others (1988); Pettijohn, Busby, and Beckman (1992, 1993a, 1993b, 1993c); Pettijohn, Busby, and Cervantes (1993a, 1993b, 1993c); and Pettijohn, Busby, and Layman (1993a, 1993b, 1993c). The geochemistry was described by Pettijohn (1996). Procedures for processing water-chemistry data were described by Pettijohn (1986), and techniques related to water chemistry interpretations of geophysical well logs were described by MacCary (1984) and Weiss (1987). Brahana and others (1985) presented ground-water quality data for the northern Mississippi embayment.

Preliminary simulations of predevelopment groundwater flow were made by Ackerman (1989a), Arthur and Taylor (1990), Brahana and Mesko (1988), Martin and Whiteman (1989), Ryder (1988), Williamson (1987), and Williamson and others (1990). Kuiper presented techniques for simulating variable density groundwater flow $(1983,1985)$, evaluated several methods for the solution of the inverse problem (1986), evaluated several numerical techniques (1987a), provided a computer program for general application (1987b), and documented the use of a nonlinear regression model, or parameter estimation model for regional ground-water flow simulation (1994). Martin and Whiteman (1990) presented a calibration and sensitivity analysis of a ground-water flow model. Brahana and Mesko (in press) presented a hydrologic analysis based on simulation of ground-water flow in the McNairy-Nacatoch aquifer in the northern Mississippi embayment. Regional interpretations of ground-water flow, based largely on computer-model simulations, were made by Grubb (1986a) and Grubb and Arthur (1991).

Ground-water withdrawals, as apportioned to each 25-square-mile area of the study area, were documented by Mesko and others (1990). Beckman and Williamson (1990) described locations of salt domes that penetrate each regional aquifer in the gulf coast aquifer systems. Prudic (1991) analyzed about 6,000 aquifer and specific capacity tests from the study area.

The final results of the Gulf Coast RASA are contained in chapters of U.S. Geological Survey Professional Paper 1416. Each chapter deals with a specific subject or with specific parts of the flow system. A regionally consistent geohydrologic framework is documented in chapters B (Hosman and Weiss, 1991) and C (Weiss, 1992), regional stratigraphy and subsurface geology is contained in chapter G (Hosman, 1996), and chapters D, E, H, and I present a hydrologic analysis based on simulations of ground-water flow in different parts of the aquifer system: the Mississippi River Valley alluvial aquifer (chapter D, Ackerman, 1996); the Texas 
Gulf Coastal Plain (chapter E, Ryder and Ardis, in press); Coastal Plain sediments of southern Louisiana, southern Mississippi, southwestern Alabama, and adjacent Florida (chapter $\mathrm{H}$, Martin and Whiteman, in press); and the Mississippi embayment (chapter I, Arthur and Taylor, in press). Chapter F (Williamson and Grubb, in press) is a regional hydrologic analysis based on simulation of ground-water flow that provides an evaluation of the effects of historical groundwater withdrawals and an evaluation of the regional potential for development of the ground-water resource. Chapter A (this report) is a summary of the hydrology of the regional aquifer systems in the Gulf Coastal Plain of the south-central United States and, in large part, is taken from the other chapters of Professional Paper 1416.

\section{GEOGRAPHY}

The study area underlies about $230,000 \mathrm{mi}^{2}$ of the Gulf Coastal Plain in parts of Alabama, Arkansas, Florida, Illinois, Kentucky, Louisiana, Mississippi, Missouri, Tennessee, and Texas, and about $60,000 \mathrm{mi}^{2}$ of the Gulf of Mexico between the coast and the edge of the Continental Shelf (fig. 2). The topography, climate, and major streams of the area influence recharge, discharge, and ground-water flow patterns, whereas population and economic activity influence ground-water withdrawals (pumpage).

Land-surface altitude ranges from sea level along the coast to more than $800 \mathrm{ft}$ in a small area of southern Texas (fig. 2). The gently sloping coastal plain is dissected by streams that are typically perpendicular to the coastline. Gently rolling hills and locally rugged topography are common except in a band across coastal Texas and Louisiana and in the broad Mississippi Alluvial Plain that extends from the mouth of the Mississippi River to the southern tip of Illinois. Land-surface altitude is typically less than $50 \mathrm{ft}$ above sea level in the coastal band across Texas and Louisiana that is 25 to $50 \mathrm{mi}$ wide. The Mississippi Alluvial Plain is the dominant topographic feature in the study area (fig. 2). It is typically 80 to $90 \mathrm{mi}$ wide but is as much as $120 \mathrm{mi}$ wide near the latitude of Little Rock, Arkansas, and as little as $30 \mathrm{mi}$ wide between Vicksburg and Natchez, Mississippi. The essentially flat alluvial plain slopes southward from about $330 \mathrm{ft}$ above sea level in Illinois, Kentucky, and Missouri to about $25 \mathrm{ft}$ above sea level at the latitude of Baton Rouge, Louisiana. From Baton Rouge southward, the Mississippi Alluvial Plain merges with the coastal band of low topography that extends across Texas and Louisiana. The hills that border the Mississippi Alluvial Plain on the east extend southward to near the coast of Mississippi and Alabama.

Several major streams that drain the area originate beyond the study area boundary and have substantial flow at the point where they enter the study area. The major rivers that have large drainage areas beyond the Gulf Coastal Plain are, from west to east, the Rio Grande, Colorado, Brazos, Red, Arkansas, Mississippi, Ohio, and Tombigbee. Other rivers that have relatively small drainage areas beyond the study area are the Frio, Guadalupe, Trinity, Sabine, Ouachita, and Escambia. The entire drainage areas of several rivers, such as the Neches, Yazoo, Pearl, and Pascagoula, are totally within the study area, and they typically have less flow than the rivers that originate outside the study area. Much water is available in the stream systems; the mean annual flows range from $775 \mathrm{ft}^{3} / \mathrm{s}$ for the Nueces River near Mathis, Tex., to $452,000 \mathrm{ft}^{3} / \mathrm{s}$ for the Mississippi River at Hickman, Ky., near the northernmost part of the study area.

The climate of the area is mostly humid subtropical, with mean annual temperature ranging from about $57^{\circ} \mathrm{F}$ in the north to about $70^{\circ} \mathrm{F}$ in the south. Mean annual precipitation ranges from less than 24 inches in southern Texas to more than 64 inches in southern Mississippi and adjacent parts of Louisiana and Alabama (fig. 3). Pan evaporation decreases from about 100 inches/yr in southern Texas to $60-65$ inches/yr throughout most of the coastal areas of Louisiana, Mississippi, and Alabama. Pan evaporation also decreases from about 65 inches/yr along the Louisiana coast to less than 45 inches/yr in southern Illinois.

A large part of the precipitation leaves the area as surface runoff. Mean annual runoff ranges from 0.2 inch in southern Texas to about 28 inches in southern Alabama (Gebert and others, 1987). Much of the precipitation that does not run off is removed from the area by evapotranspiration. Most recharge to the water table is discharged nearby and provides base flow of streams. Only a small fraction, typically less than $1 \mathrm{inch} / \mathrm{yr}$, is left to recharge the regional ground-water system except in areas with large ground-water pumpage (Williamson and others, 1990).

\section{POPULATION AND ECONOMY}

Population within the study area grew at the rate of about one-quarter million per decade during the period 1970-90 and reached a total of 20.4 million by 1990 (fig. 4). This growth rate was about a factor of 2 greater than the fairly steady population growth rate during the previous four decades. In addition to the increase in population, there was a large movement of people from 


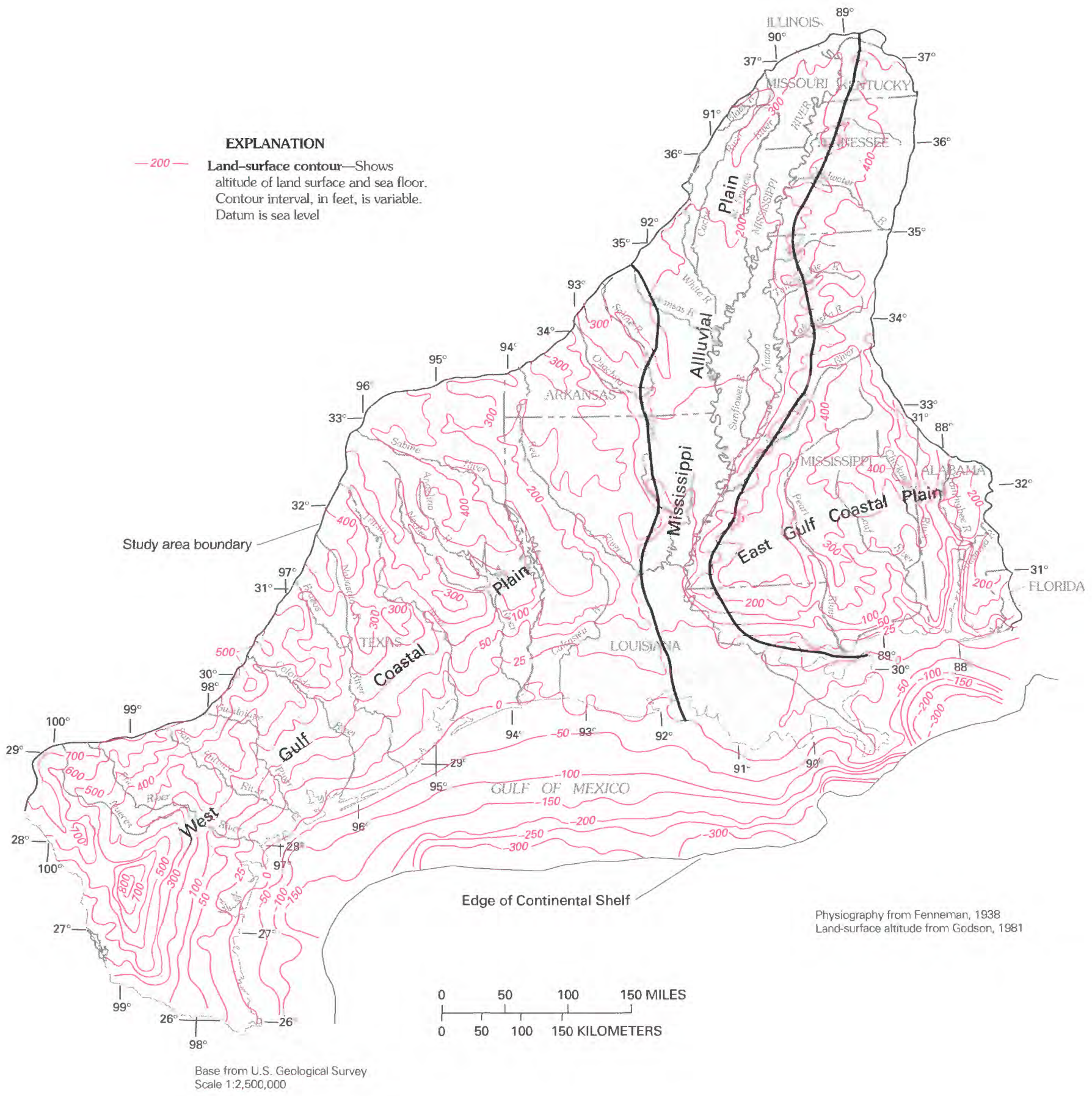

FIGURE 2.-Generalized average land-surface altitude, bathymetry, major rivers, and physiographic provinces. 


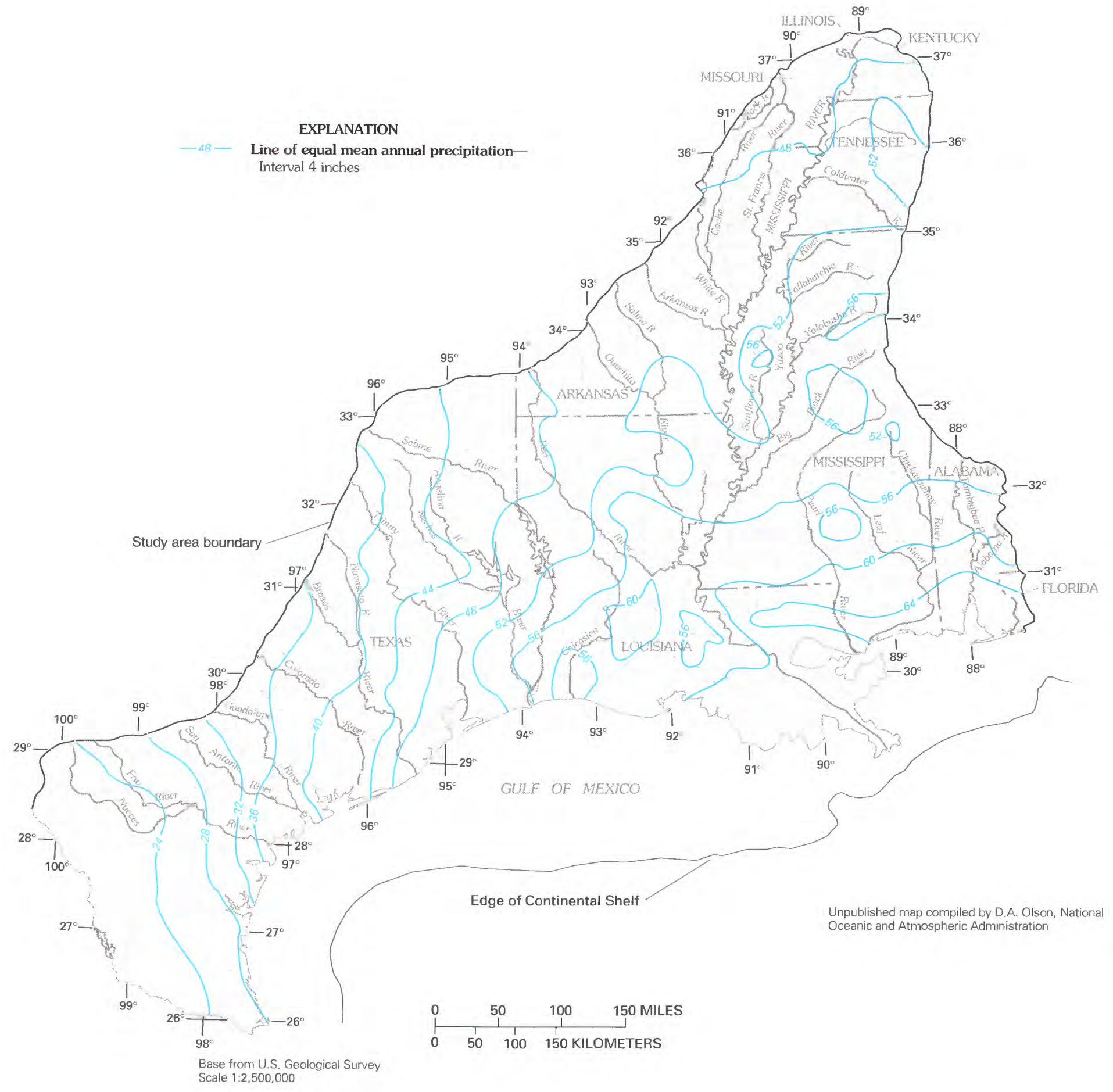

FigURE 3.-Mean annual precipitation, 1951-80. 

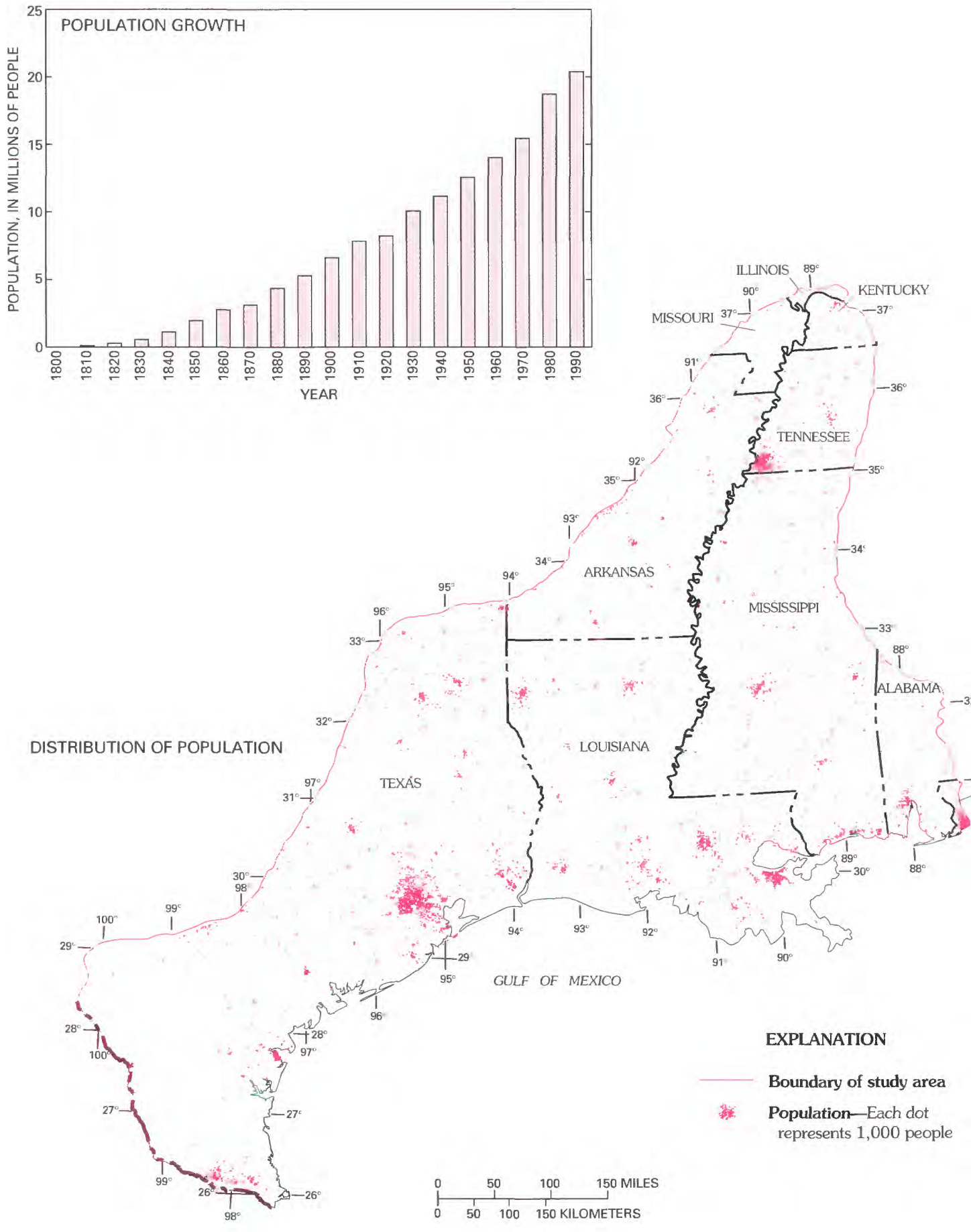

FIGURE 4.-Distribution of population in 1985 and popuiation growth, 1800-1990. 
rural areas to urban areas, with Louisiana and Texas having more people living in cities than in rural areas by 1950 . Large pumping centers have developed near the more densely populated areas of figure 4 . Both the increase in population and the movement of people to cities have contributed to the increase in ground-water use in the study area.

Agricultural activities are widespread throughout the study area and have been important to the economy of the various States for many years. Some of the highvalue crops are rice, commercial vegetables, row crops such as corn and soybeans, and fish farming or aquaculture. Agricultural activities that typically demand large quantities of water are the growing of rice and commercial vegetables, and aquaculture; an increase in each activity has caused an increase in ground-water withdrawals over the years.

Industrial activities are economically important in the study area, and large quantities of water are used by industry. Growth of industrial activities such as the petrochemical and paper industries has contributed to increased ground-water withdrawals.

\section{GEOLOGY}

The aquifers of interest are in a gulfward-thickening wedge of sedimentary deposits of mostly Cenozoic age. Maximum thicknesses of normally pressured sediments range from about 14,000 to $18,000 \mathrm{ft}$ throughout a large area of coastal Louisiana. The sediments crop out in a typical offlap relation. Older sediments are at the land surface at the updip limit of the study area, and progressively younger sediments crop out gulfward in bands parallel to the Gulf of Mexico or the axes of major embayments. The typically unconsolidated to semiconsolidated sediments are a complexly interbedded sequence of sand, silt, and clay with minor beds of lignite, gravel, and limestone. The following summary of the geology was adapted from much more extensive discussions by Hosman (1996), Weiss (1992), and Hosman and Weiss (1991).

Deposition during the Tertiary Period was affected by regional crustal subsidence, inflow of sediment from beyond the Gulf Coastal Plain, and eustatic sea-level change (Galloway, 1989). The principal structural features such as the Gulf Coast geosyncline and the Mississippi embayment (fig. 5) reflect the configuration and deformation of the underlying Paleozoic rocks. Subsidiary structural features such as uplifts, embayments, and fault zones began to form prior to the Tertiary Period and continued to develop as localized subsidence occurred at the mouths of large stream systems where sediment carried from the interior of the conti- nent was deposited in vast quantities (Wilhelm and Ewing, 1972). Gravity flow of buried sediments near the margins of thick deltaic deposits resulted in growth faulting and thickening of the strata in a gulfward direction. Excess fluid pressure (also called geopressure) developed as sediments were buried more rapidly than fluids could be expelled from compacting sediments. The landward migration of marine environments resulted in the deposition of massive marine clays as sea levels rose periodically throughout the Cenozoic Era.

Marine clays of the Midway Group (Paleocene) form the basal confining unit of the ground-water flow system in most of the study area. All stratigraphic units plunge into the Gulf Coast geosyncline to the south, and the sand aquifers pinch out by facies change to clay and silt or are truncated by the geopressured zone. The Wilcox Group (Paleocene and Eocene) overlies the Midway Group and contains sand beds of widely varying thickness and texture. The Wilcox Group contains massive sand beds in places, notably in the northern part of the Mississippi embayment, although most of the group is composed of interbedded thin sands, clays, and silts. The overlying Claiborne Group (Eocene) is generally a thick sequence of massive sand beds separated by thick, extensive marine clay beds. The sand beds of the Wilcox and Claiborne Groups form regionally extensive aquifers that are typically confined by areally extensive marine clay beds.

The marine clays of the combined Jackson (Eocene) and Vicksburg (Oligocene) Groups overlie the Claiborne Group and form an extensive regional confining unit throughout the southern part of the study area. Gulfward of the outcrop area of the Vicksburg Group, strata of the overlying Miocene Series contains sand beds of varying thickness that are complexly interbedded with silt and clay. Typically, Miocene sand beds are not as massive, or they do not extend throughout as large an area, as the sand beds of the Claiborne Group. Numerous interbedded clays, which are not traceable throughout large geographic areas, are a substantial restriction to vertical ground-water flow in the Miocene sands. Deposits of the Pliocene Series overlie Miocene deposits gulfward of the Miocene outcrop area, and Pliocene sands generally are hydraulically connected and contain no regionally extensive confining units. Terrace (Pleistocene) and alluvial (Holocene) deposits overlie Pliocene sediments in a wide band adjacent to the Gulf of Mexico and extend northward throughout most of the central and western parts of the Mississippi embayment where they overlie strata of Miocene through Paleocene age (fig. 5). These terrace and alluvial deposits are hydraulically connected to streams and underlying Tertiary deposits. Sediments of Oli- 


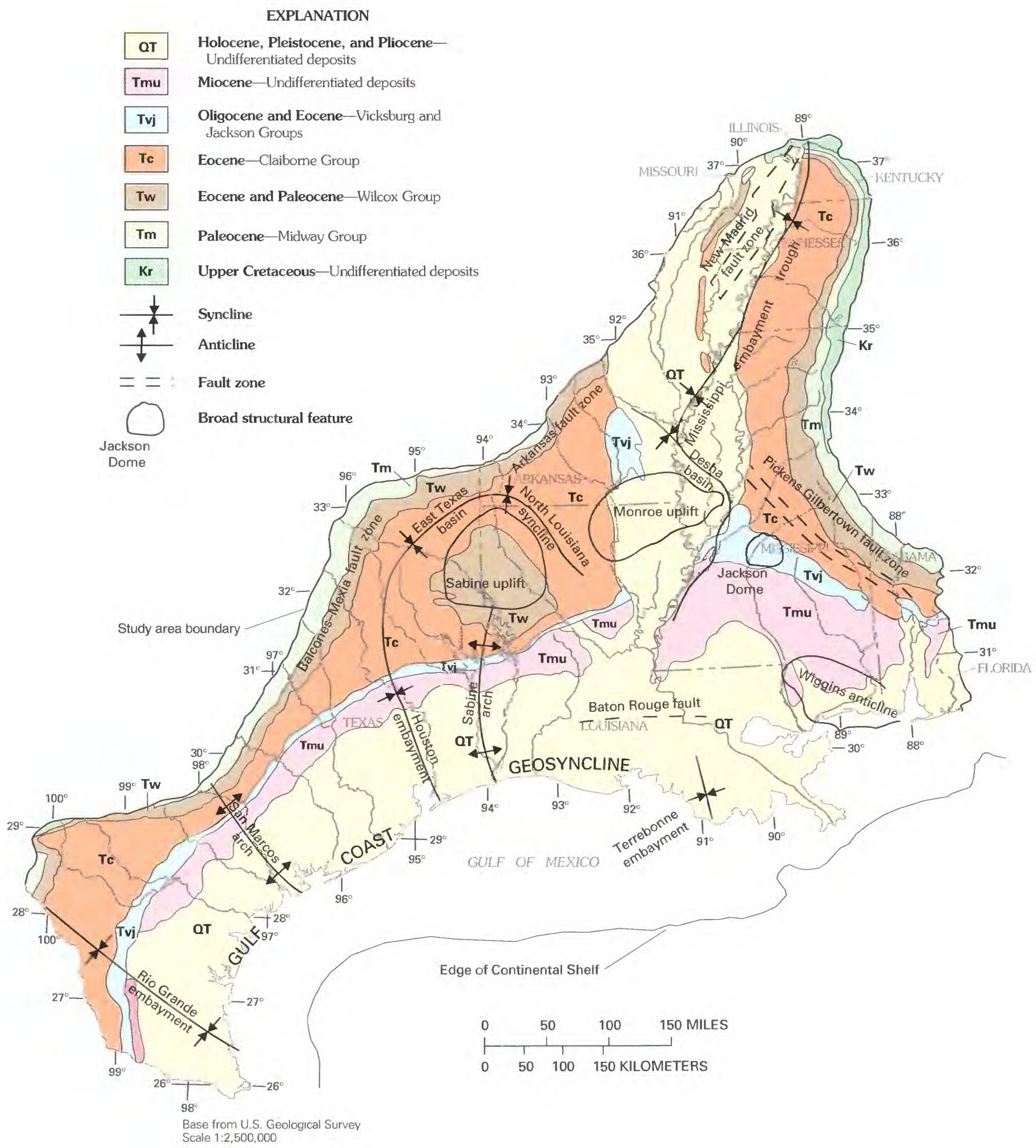

FIGURE 5.-Generalized geology and structural features, Gulf Coastal Plain, south-central United States. 
gocene age and younger commonly lack areally extensive marine clays and therefore contain no regional confining units.

Major structural features (fig. 5) affected sediment deposition during the Tertiary Period. Sediments thin toward and over uplifted features such as the San Marcos arch, Sabine uplift, Monroe uplift, and Jackson dome. Sediments typically are thicker in depressions such as the Rio Grande, Houston, Terrebonne, and Mississippi embayments and the Gulf Coast geosyncline.

The regional growth-fault zones that typically parallel the coastline do not appear to be a major control on regional ground-water flow but may be significant controls locally. However, these faults as well as the major structural features are important controls on the accumulation and movement of hydrocarbons.

Salt-dome basins are present across the area from southern Texas to southwestern Alabama (Halbouty, 1979). The domes can penetrate most or all Tertiary strata at any given location although only a few are at or near the land surface. Salt domes that penetrate geohydrologic units within the study area were identified by Beckman and Williamson (1990). The source of the salt is generally considered to be the deeply buried Louann Salt of Jurassic age (Andrews, 1960). Faulting associated with the salt domes is localized; the domes typically are only 1 to $3 \mathrm{mi}$ in diameter. The effects of salt domes on regional ground-water flow in the freshwater part of the flow system is also localized. However, dissolution of salt in the deeply buried parts of the salt basins may affect regional ground-water movement in strata that contain highly mineralized water.

\section{GEOHYDROLOGIC FRAMEWORK}

Three aquifer systems are present in the study area: the coastal lowlands aquifer systems, Texas coastal uplands, and the Mississippi embayment (fig. 6). These aquifer systems, in sediments of Cenozoic age, have been divided into six regional aquifers and five permeable zones (fig. 7 and table 1). The geohydrology of each of the three aquifer systems is described by Hosman and Weiss (1991) and Weiss (1992); both of these reports present maps of the thickness, percentage of sand, and altitude and configuration of the top of each wateryielding unit, along with a discussion of the general geology. Hosman and Weiss (1991) also include maps for the McNairy-Nacatoch aquifer in sediments of Cretaceous age that underlie the Mississippi embayment aquifer system in the northern part of the study area.

The aquifers and permeable zones range in areal extent from about $32,000 \mathrm{mi}^{2}$ (the Mississippi River Valley alluvial aquifer) to about $170,000 \mathrm{mi}^{2}$ (the middle
Wilcox aquifer, fig. 8). The Mississippi River Valley alluvial aquifer has the smallest average thickness (140 $\mathrm{ft}$ ), and permeable zone C (lower Pliocene-upper Miocene deposits) has the largest average thickness $(2,010 \mathrm{ft})$. Average percentage of sand ranges from 34 percent in the middle Wilcox aquifer to 86 percent in the lower Claiborne-upper Wilcox aquifer (table 2). The permeable zones and aquifers typically thicken from outcrop toward the Gulf of Mexico or toward the axes of major embayments; however, near their downdip limits the water-yielding units become thinner as the sediments grade into marine clay facies or the top of the geopressured zone truncates the ground-water flow system.

The aquifers in the Mississippi embayment and laterally equivalent Texas coastal uplands aquifer systems typically consist of one or more massive sand beds and are separated from each other by confining units of regionally extensive clay beds. The sediments of the coastal lowlands aquifer system typically consist of interbedded sand and clay beds that are not regionally extensive. Accordingly, these sediments were divided vertically into permeable zones on the basis of sharp changes in vertical hydraulic head gradients and local lithology as explained by Weiss (1992) and Weiss and Williamson (1985).

A regional permeable zone (permeable zone B) and a regional aquifer (the middle Claiborne aquifer) are used for illustrative purposes in this summary. Thus in the following discussion of geohydrologic units, maps of thickness are shown only for permeable zone B and the middle Claiborne aquifer. Thickness and altitude of the top of each regional geohydrologic unit and percentage of sand for aquifers and permeable zones are presented by Hosman and Weiss (1991) and Weiss (1992).

\section{COASTAL LOWLANDS AQUIFER SYSTEM}

The base of the coastal lowlands aquifer system is the Vicksburg-Jackson confining unit except for an area that includes the Continental Shelf and a narrow band onshore along the coast of Texas and Louisiana. In this area, the base of the flow system is the top of the geopressured zone, which is above the top of the sediments that comprise the confining unit (Grubb, 1986b). The confining unit has a maximum thickness of about $6,000 \mathrm{ft}$ in southeastern Louisiana and an average thickness of about $500 \mathrm{ft}$.

There are five permeable zones and two confining units within the coastal lowlands aquifer system (figs. 7, 9). The two confining units are present only in the subsurface. The permeable zones typically consist of 


\section{EXPLANATION}

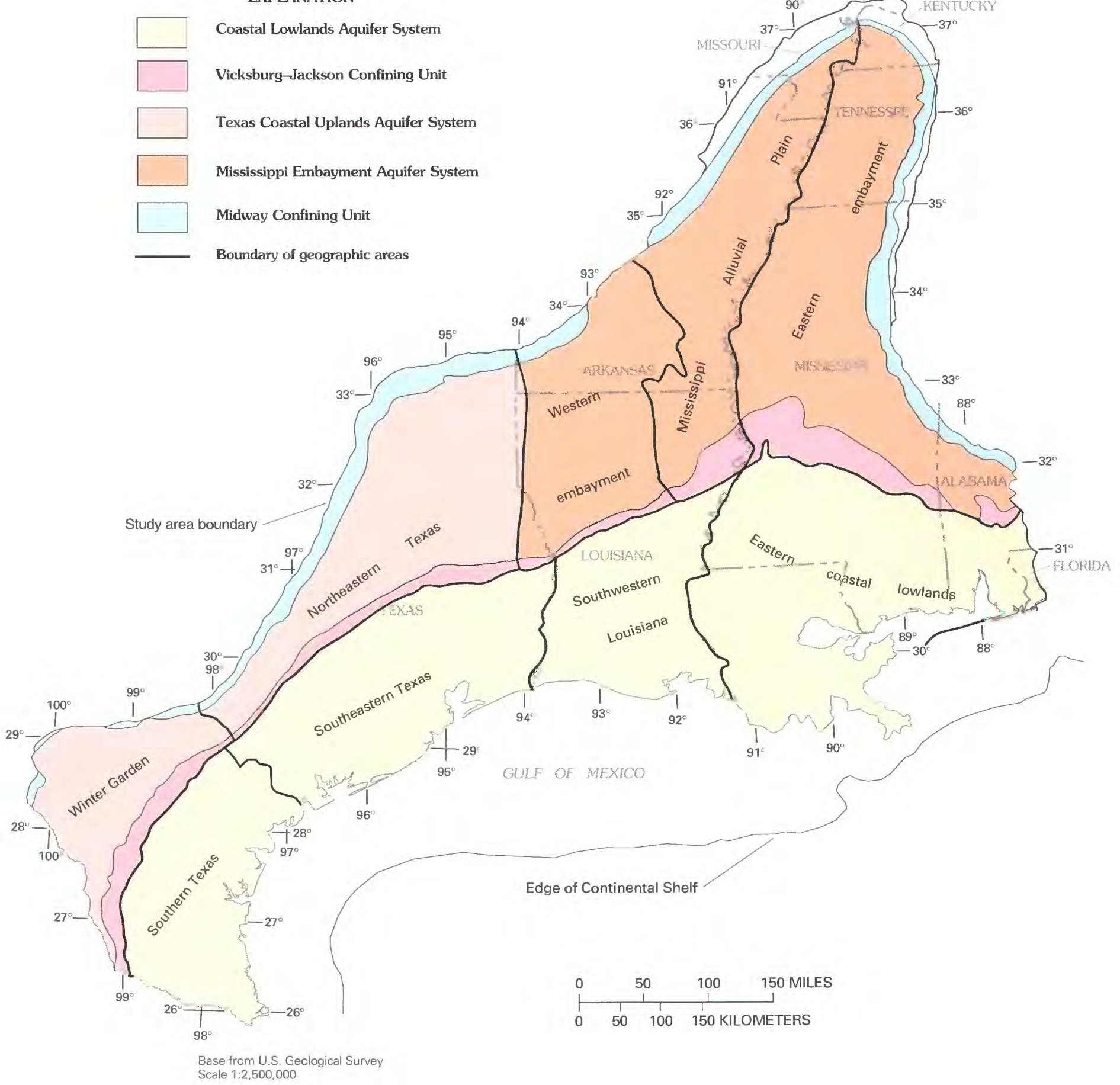

FIGURE 6-Generalized outcrop of aquifer systems, intervening regional confining units, and designated geographic areas. 


\section{EXPLANATION}

Coastal lowlands aquifer system permeable zones A-E

Zone A (Holocene-upper Pleistocene deposits.

South of Vicksburg-Jackson confining unit)

Zone B (lower Pleistocene-upper Pliocene deposits)

Zone C (lower Pliocene-upper Miocene deposits)

Zone D (middle Miocene deposits)

Zone E (lower Miocene-upper Oligocene deposits)

Vicksburg-Jackson confining unit-Base of the coastal lowlands aquifer system

Mississippi embayment and Texas coastal uplands aquifer systems

* Mississippi River Valley alluvial aquifer (north of permeable zone $\mathrm{E}$

Upper Claiborne aquifer

Middle Claiborne confining unit

Middle Claiborne aquifer

Lower Claiborne confining unit

Lower Claiborne-upper Wilcox aquifer

Middle Wilcox aquifer

Lower Wilcox aquifer

Midway Confining Unit-Base of Missisippi embayment and Texas coastal uplands aquifer system

McNairy-Nacatoch aquifer

- - - Indicates units subcrop beneath Mississippi River Valley alluvial aquifer * Not present in Texas coastal uplands aquifer system

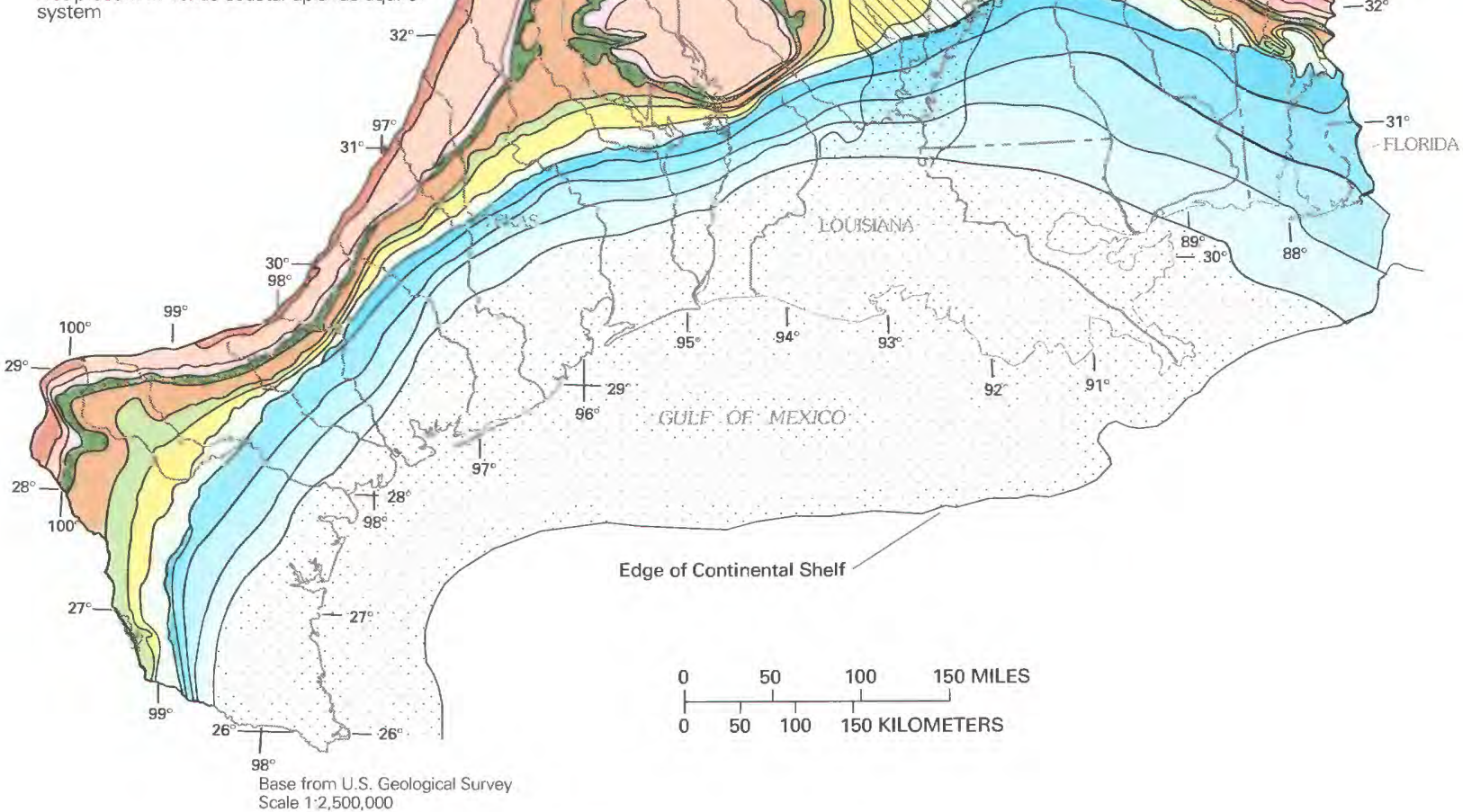

FIGURE 7.-Generalized outcrop of regional geohydrologic units. 


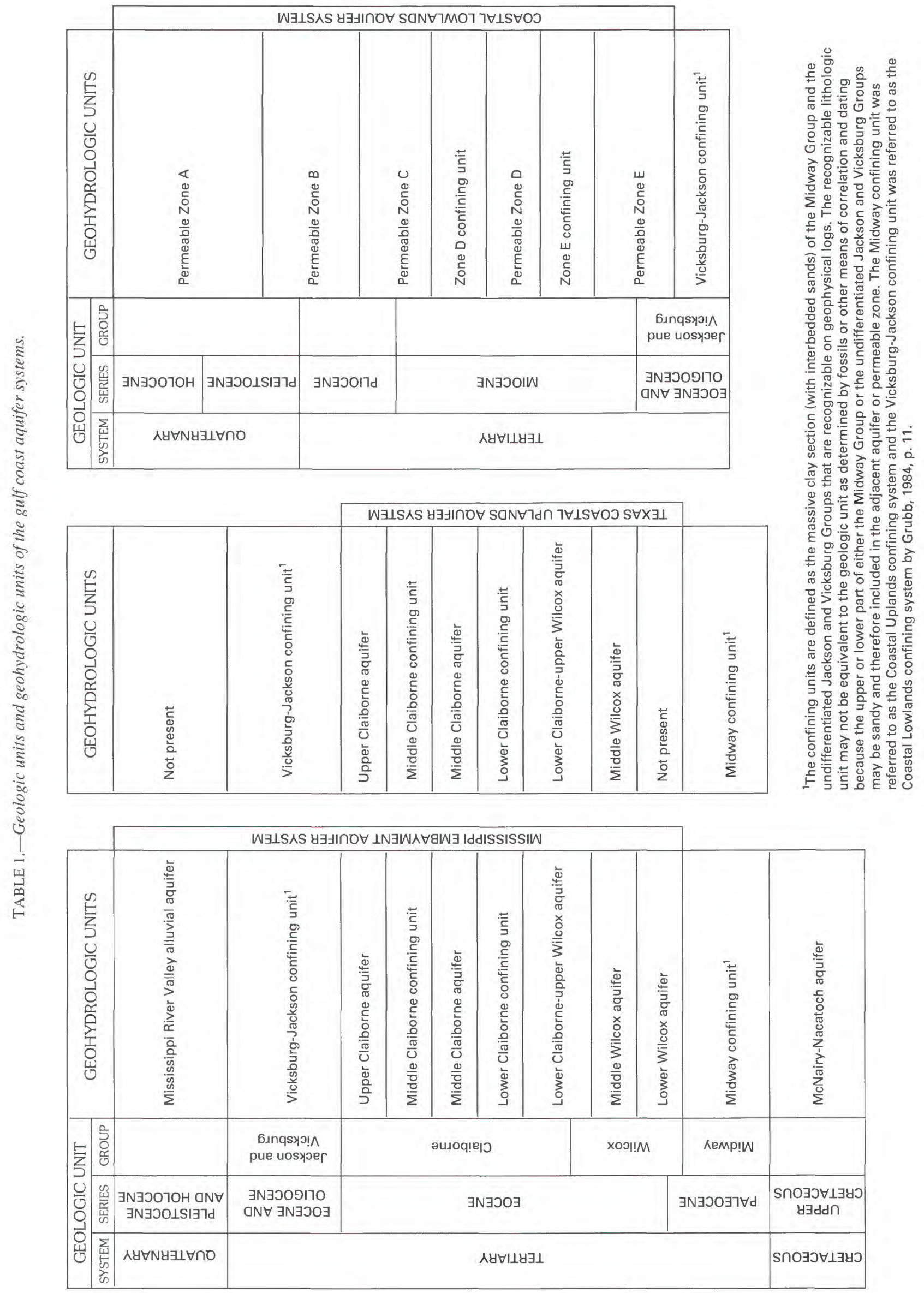




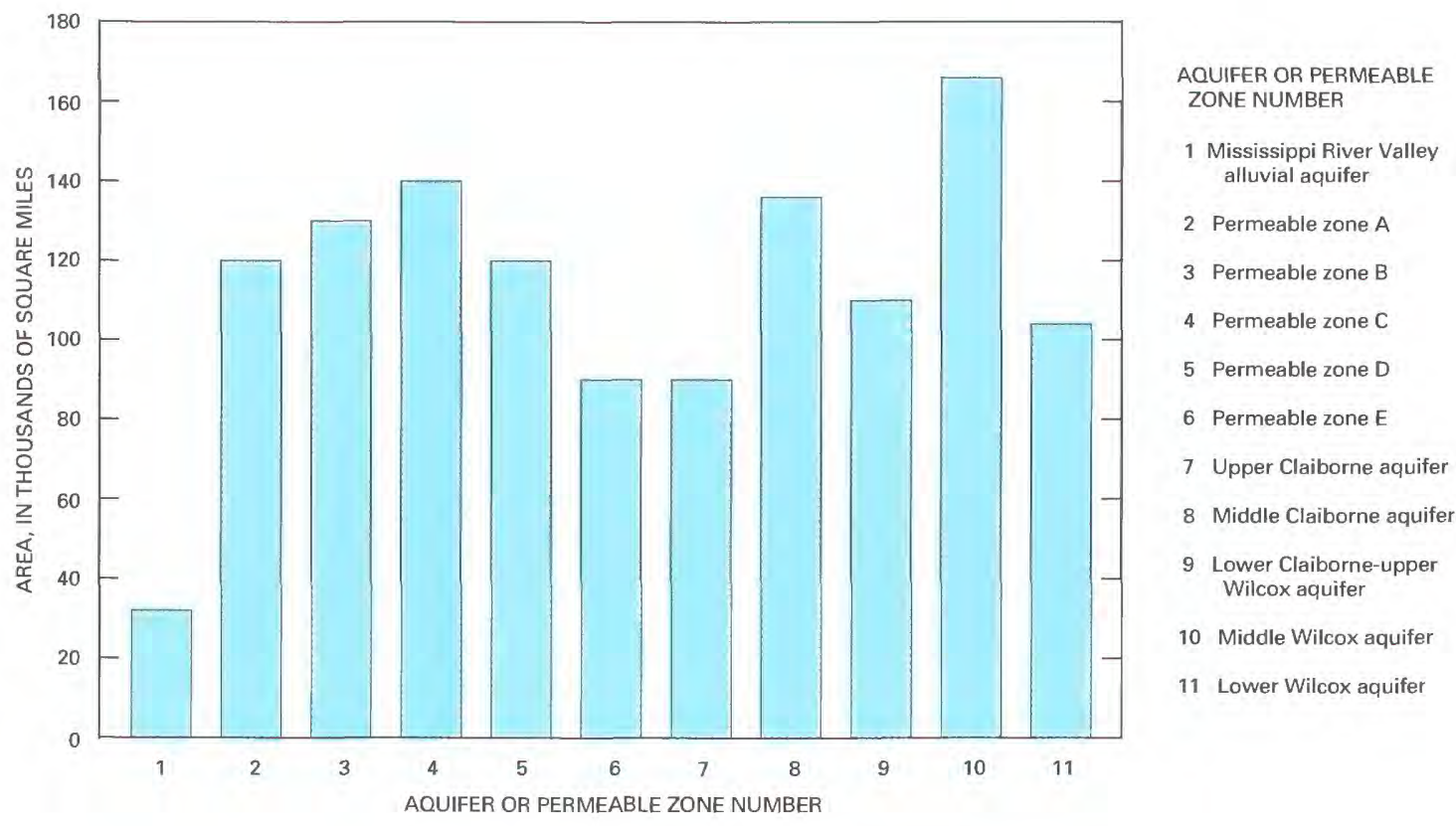

Figure 8.-Areal extent of aquifers and permeable zones.

interbedded sand and clay rather than the areally extensive and massive sands that are typical of the other two aquifer systems. Also, the permeable zones in the coastal lowlands aquifer system generally contain a smaller percentage of sand than the aquifers in the other two aquifer systems except for the middle Wilcox aquifer in the Mississippi embayment aquifer system (table 2). The permeable zones were delineated on the basis of hydraulic heads and local lithology as described by Weiss and Williamson (1985) because of the complexly interbedded nature of the sediments and the absence of areally extensive marker beds that are hydrologically significant. The method that they describe divides the entire thickness of the sediments above the Vicksburg-Jackson confining unit such that the hydraulic-head differences between permeable zones are greater than those within the permeable zones, especially in areas where ground-water withdrawals have created large vertical hydraulic-head gradients. The permeable zones were designated, from youngest to oldest, A through $\mathrm{E}$, as shown in table 1.

Permeable zone A (Holocene-upper Pleistocene deposits) has an area of about $120,000 \mathrm{mi}^{2}$. The zone directly overlies zone B (table 1), except for a narrow band about $50 \mathrm{mi}$ wide along the Mississippi River, and extends northward from the main body of the zone to the subcrop of the Vicksburg-Jackson confining unit. In this small area that extends northward from the Vicksburg-Jackson confining unit and parallels the Mississippi River, permeable zone A overlies the other permeable zones of the coastal lowlands aquifer system. Permeable zone $\mathrm{A}$ has an average thickness of about $540 \mathrm{ft}$ and a maximum thickness of about 1,200 ft offshore from east-central Louisiana. The zone has an average sand content of about 65 percent (table 2). Sand content exceeds 80 percent in several small, isolated areas (a few hundred square miles in extent) in Texas and throughout a large area of several thousand square miles in central Louisiana. A large, nearly continuous area where the sand content is less than 20 percent is present adjacent to the downdip limit of the zone.

Permeable zone B (lower Pleistocene-upper Pliocene deposits) (fig. 10) has an area of about 130,000 $\mathrm{mi}^{2}$. It directly overlies zone C (lower Pliocene-upper Miocene deposits) (table 1) and the two zones are not separated by a confining unit. Zone $B$ has an average thickness of about 1,900 ft (table 2) and a maximum thickness of about 5,700 ft offshore from east-central Louisiana. The thickest part of permeable zone B extends throughout a large area of offshore Louisiana. The permeable zone thickens gulfward from its outcrop area toward the edge of the Continental Shelf and from west to east toward the Terrebonne embayment. The small area where the zone is less than $3,000 \mathrm{ft}$ thick near the edge of the Continental Shelf offshore from Louisiana (fig. 10) is due to the truncation of the permeable zone from below by the geopressured zone. Permeable zone B has an average sand content of about 48 percent. There are four small isolated areas (a few hundred square miles in extent) where the sand content exceeds 
80 percent. Three of these areas extend to the updip limit of the zone in Texas east of the San Marcos uplift. There are only two small areas where the sand content is less than 20 percent in updip areas. Both are in or near the outcrop area of the permeable zone in Mississippi. A

TABLE 2. Summary of thickness and sand percentage of aquifers and permeable zones

[Values for thickness and sand percentage are the average of the data from the well-log file described by Grubb (1986b, p. 157); --, not present]

\begin{tabular}{lccccc}
\hline \multirow{2}{*}{ Aquifer } & \multicolumn{3}{c}{ Mississippi embayment aquifer system } \\
\cline { 2 - 3 } & \multicolumn{2}{c}{$\begin{array}{c}\text { Thickness } \\
\text { (feet) }\end{array}$} & & \multicolumn{2}{c}{ Sand percentage } \\
\cline { 2 - 3 } \cline { 5 - 6 } & Maximum & Average & Average & $\begin{array}{c}\text { Standard } \\
\text { deviation }\end{array}$ \\
\hline $\begin{array}{l}\text { Mississippi River Valley } \\
\quad \text { alluvial }\end{array}$ & 350 & 140 & & 70 & -- \\
$\begin{array}{l}\text { Upper Claiborne } \\
\text { Middle Claiborne }\end{array}$ & 1,180 & 310 & & 52 & 23 \\
Lower Claiborne-upper & 1,090 & 485 & & 57 & 22 \\
$\quad$ Wilcox & 940 & 270 & & 71 & 26 \\
Middle Wilcox aquifer & 4,060 & 1,020 & & 34 & 18 \\
Lower Wilcox aquifer & 1,290 & 330 & 67 & 24 \\
\hline \hline
\end{tabular}

\begin{tabular}{|c|c|c|c|c|}
\hline \multirow{3}{*}{ Aquifer } & \multicolumn{4}{|c|}{ Texas coastal uplands aquifer system } \\
\hline & \multicolumn{2}{|c|}{$\begin{array}{l}\text { Thickness } \\
\text { (feet) }\end{array}$} & \multicolumn{2}{|c|}{ Sand percentage } \\
\hline & Maximum & Average & Average & $\begin{array}{l}\text { Standard } \\
\text { deviation }\end{array}$ \\
\hline $\begin{array}{l}\text { Mississippi River Valley } \\
\text { alluvial }\end{array}$ & (1) & - & -- & -- \\
\hline Upper Claiborne & 2,490 & 970 & 51 & 15 \\
\hline Middle Claiborne & 2,530 & 570 & 60 & 19 \\
\hline $\begin{array}{l}\text { Lower Claiborne-upper } \\
\text { Wilcox }\end{array}$ & 1,300 & 360 & 86 & 14 \\
\hline Middle Wilcox aquifer & 5,200 & 1,790 & 55 & 15 \\
\hline Lower Wilcox aquifer & (1) & -- & -- & -- \\
\hline
\end{tabular}

\begin{tabular}{cccccc}
\hline & \multicolumn{3}{c}{ Coastal lowlands aquifer system } \\
\cline { 2 - 3 } Permeable zone & $\begin{array}{c}\text { Thickness } \\
\text { (feet) }\end{array}$ & & \multicolumn{2}{c}{ Sand percentage } \\
\cline { 2 - 3 } \cline { 5 - 6 } & Maximum & Average & Average & $\begin{array}{c}\text { Standard } \\
\text { deviation }\end{array}$ \\
\hline $\begin{array}{c}\text { Zone A (Holocene-upper } \\
\text { Pleistocene deposits }\end{array}$ & 1,220 & 540 & & 65 & 28 \\
$\begin{array}{c}\text { Zone B (lower Pleistocene- } \\
\text { upper Pliocene deposits) }\end{array}$ & 5,650 & 1,880 & & 48 & 21 \\
$\begin{array}{c}\text { Zone C (lower Pliocene- } \\
\text { upper Miocene deposits) }\end{array}$ & 6,330 & 2,010 & & 45 & 20 \\
$\begin{array}{c}\text { Zone D (middle Miocene } \\
\text { deposits) }\end{array}$ & 7,580 & 1,830 & & 44 & 19 \\
$\begin{array}{c}\text { Zone E (lower Miocene- } \\
\text { upper Oligocene deposits) }\end{array}$ & 4,450 & 1,420 & & 42 & 18 \\
\hline
\end{tabular}

(1) Aquifer not present in the Texas coastal uplands aquifer system . sand content of less than 20 percent is present in a large, nearly continuous area adjacent to the downdip limit of the zone.

Permeable zone C (lower Pliocene-upper Miocene deposits) has an area of about $140,000 \mathrm{mi}^{2}$ and extends gulfward to the edge of the Continental Shelf. It overlies permeable zone D (middle Miocene deposits) (table 1) in the outcrop and adjacent downdip area (about $25,000 \mathrm{mi}^{2}$ ) and overlies the zone D confining unit (which is present only in the subsurface, fig. 9) throughout its remaining downdip area of occurrence. Permeable zone $C$ has an average thickness of about 2,000 ft (table 2) and a maximum thickness of about $6,300 \mathrm{ft}$ on the Continental Shelf about midway between the east-central Louisiana shoreline and the edge of the shelf. The zone has an average sand content of about 45 percent (table 2 ). There are three relatively small areas (a few hundred square miles in extent) in southern Mississippi where the sand content is more than 80 percent. Four small isolated areas where the sand content is less than 20 percent are present-two in southern Texas and two in southern Mississippi. A large, continuous area (tens of thousands of square miles in extent) where the sand content is less than 20 percent is present adjacent to the downdip limit of the permeable zone.

Permeable zone D (middle Miocene deposits) has an area of about $120,000 \mathrm{mi}^{2}$. It overlies permeable zone $\mathrm{E}$ (lower Miocene-upper Oligocene deposits) (table 1) in the outcrop and adjacent updip area (about 50,000 $\mathrm{mi}^{2}$ ) and overlies the zone $\mathrm{E}$ confining unit (which is present only in the subsurface, fig. 9) throughout its remaining downdip area of occurrence (about $44,000 \mathrm{mi}^{2}$ ). Permeable zone $\mathrm{D}$ has an average thickness of about $1,800 \mathrm{ft}$ (table 2) and a maximum thickness of more than 7,500 ft in southeastern Louisiana. The zone has an average sand content of about 44 percent (table 2). There are only three small areas (a few hundred square miles in extent) in the eastern part of the outcrop area where the sand content exceeds 80 percent. There are several isolated areas (a few thousands of square miles in extent) in both updip and downdip areas where the sand content is less than 20 percent.

Permeable zone E (lower Miocene-upper Oligocene deposits) overlies the Vicksburg-Jackson confining unit and has an area of about $90,000 \mathrm{mi}^{2}$. The zone has an average thickness of about $1,400 \mathrm{ft}$ and a maximum thickness of $4,450 \mathrm{ft}$ in southern Texas about midway between the Rio Grande and the axis of the San Marcos arch. The permeable zone has an average sand content of about 42 percent sand (table 2) and does not have any large area where the sand content is more than 80 percent. However, permeable zone $\mathrm{E}$ has a sand content of 60-80 percent in three areas of several thousand square miles in extent. Two areas are in Texas, one near and 


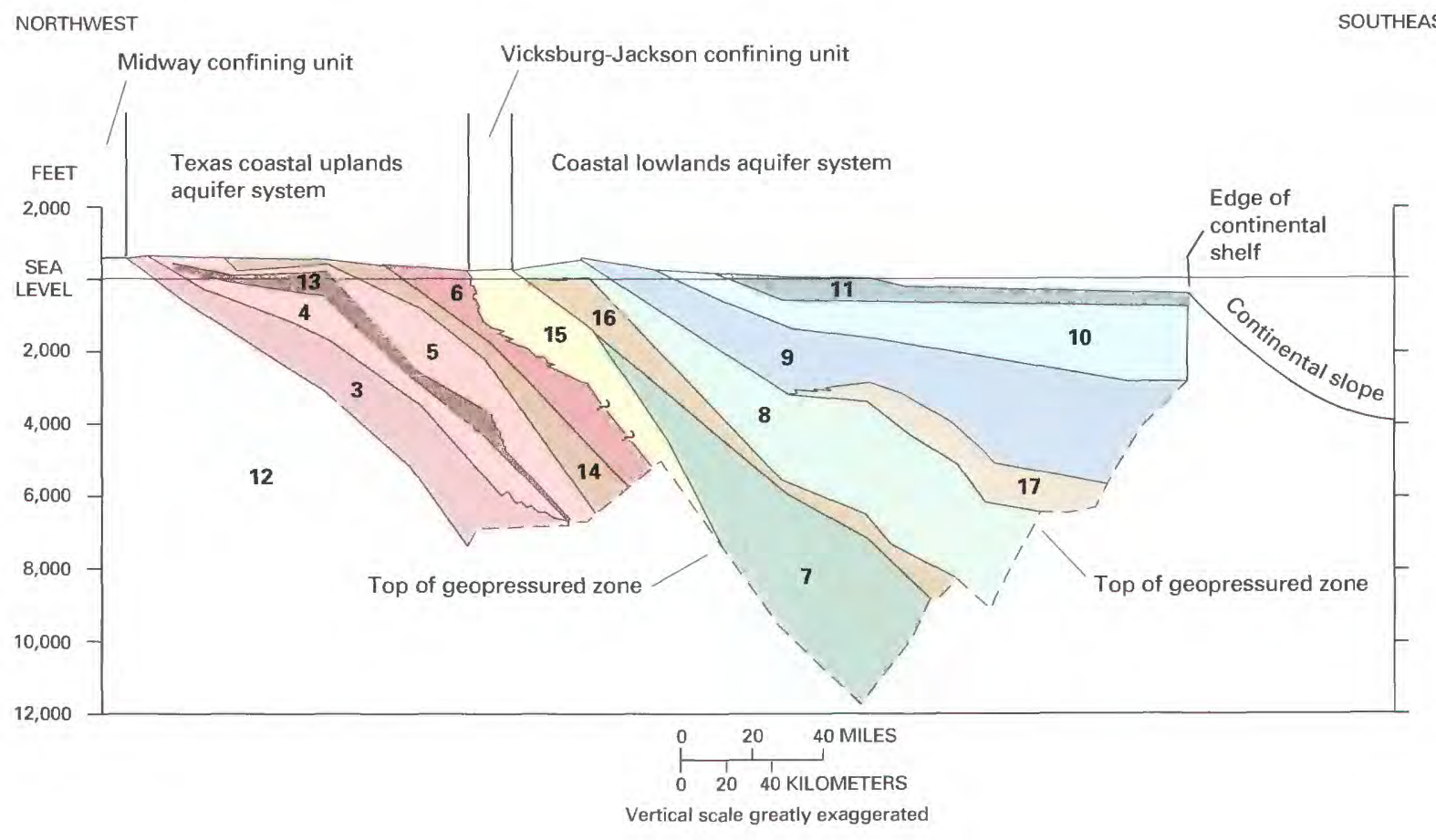

EXPLANATION

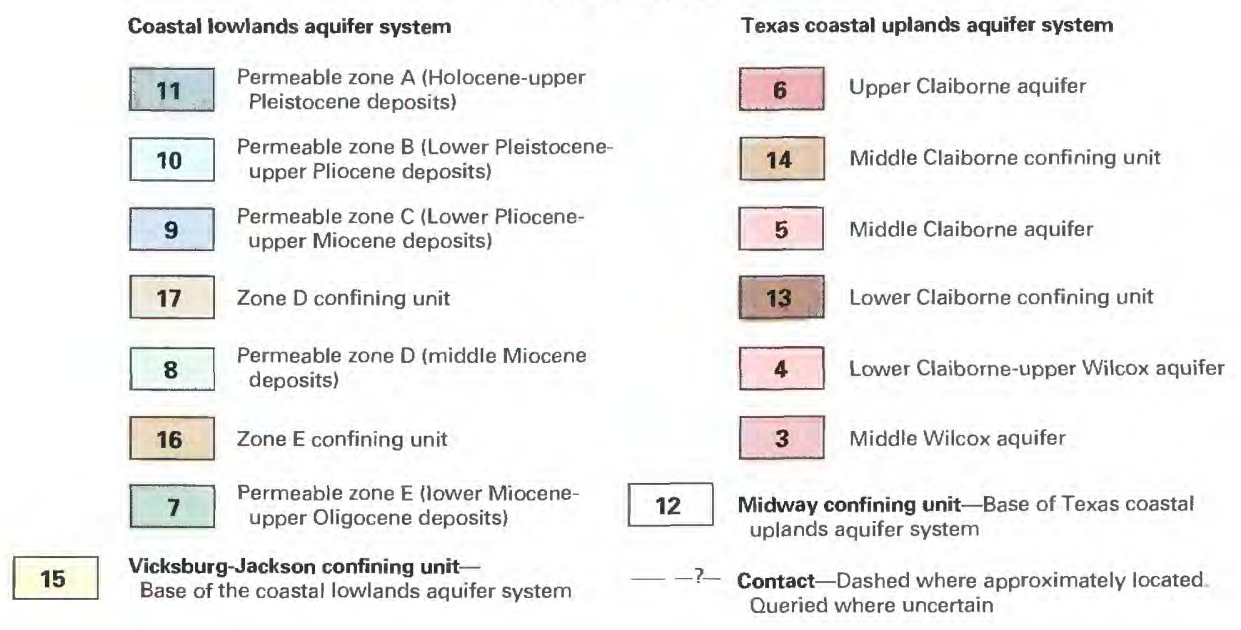

FIGURE 9.-Idealized section from boundary of study area in Zavala County, Texas, southeastward through Kleberg County, Texas, to the Continental Slope, showing relation of geohydrologic units.

parallel to the coast from the Rio Grande to the vicinity of the axis of the San Marcos arch, and the other near the coast in southeastern Texas. The third area extends from the outcrop area in southeastern Mississippi to the coast at the Mississippi-Louisiana State boundary. There are several small areas (several hundred square miles in extent) near the updip limits of the zone where the sand content is less than 20 percent. Another narrow band where the sand content is less than 20 percent occurs near the downdip limit of permeable zone $\mathrm{E}$ from western Louisiana to western Florida.

\section{TEXAS COASTAL UPLANDS AQUIFER SYSTEM}

The aquifers and confining units that compose this aquifer system range in age from Paleocene to late Eocene and are laterally equivalent to those of the Mississippi embayment aquifer system. The base of the system is the Midway confining unit except along a band that is as much as $30 \mathrm{mi}$ wide where the top of the geopressured zone is the base. Near the downdip limit of the aquifer system, the geopressured zone is above the top of the sediments that compose the Midway confining unit. There are four aquifers and two confining 


\section{EXPLANATION}

Outcrop or subcrop areaDashed where concealed

Line of equal thickness-

Interval, in feet, is variable

Depth-averaged dissolved-solids

concentration-More than 10,000

milligrams per liter where shaded

Downdip limit of permeable zone
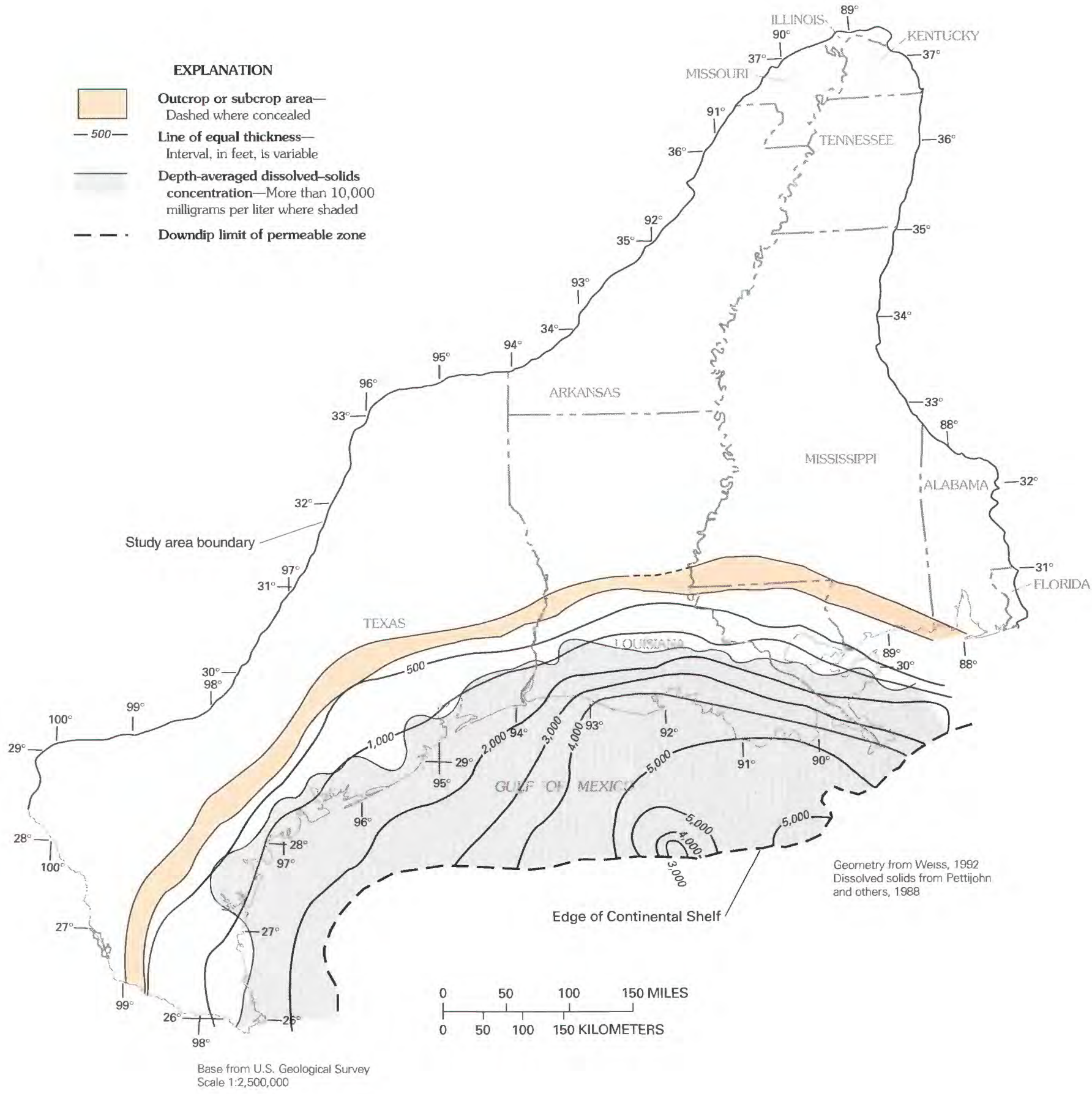

FIGURE 10.-Thickness of permeable zone B (lower Pleistocene-upper Pliocene deposits), coastal lowlands aquifer system. 
units within the Texas coastal uplands aquifer system (table 1). The aquifers in the Texas coastal uplands aquifer system typically are thicker and contain more sand than equivalent aquifers in the Mississippi embayment aquifer system (table 2). Two aquifers, the middle Claiborne and the lower Claiborne-upper Wilcox, are not present throughout an area of about $6,000-9,000 \mathrm{mi}^{2}$ centered on the Texas-Louisiana State boundary. In this area, lack of deposition or erosion of younger units on the Sabine uplift has resulted in the middle Wilcox aquifer being the uppermost geohydrologic unit (fig. 7). The width of the outcrop areas is generally narrower in the Texas coastal uplands aquifer system than in the Mississippi embayment aquifer system.

The upper Claiborne aquifer has an area of about $45,000 \mathrm{mi}^{2}$ and overlies the middle Claiborne confining unit (table 1). The aquifer has an average thickness of about $970 \mathrm{ft}$ and is about 51 percent sand. There are no extensive areas where the aquifer contains more than 80 percent or less than 20 percent sand. The middle Claiborne confining unit separates the upper Claiborne aquifer from the underlying middle Claiborne aquifer and has an average thickness of about $150 \mathrm{ft}$.

The middle Claiborne aquifer (fig. 11) has an area of about $36,000 \mathrm{mi}^{2}$ and overlies the lower Claiborne confining unit (table 1). The aquifer has an average thickness of about $570 \mathrm{ft}$ and is about 60 percent sand (table 2). The thickest part of the middle Claiborne aquifer is in the Rio Grande embayment of southern Texas, where it is more than $2,500 \mathrm{ft}$ thick. The major cause of thinning of the middle Claiborne aquifer near its downdip limit is the decrease in permeability due to facies change. The geopressured zone forms the base of the aquifer along a band about $20 \mathrm{mi}$ wide and $100 \mathrm{mi}$ long adjacent to the downdip limit of the aquifer, in southern Texas and trending northeastward from the Rio Grande. The aquifer is more than 80 percent sand in two small areas near the Sabine uplift; the total of the combined areas is less than $2,000 \mathrm{mi}^{2}$. The aquifer is less than 40 percent sand in a narrow band of several thousand square miles near its downdip limit. The middle Claiborne aquifer is separated from the underlying lower Claiborne-upper Wilcox aquifer by the lower Claiborne confining unit, which has an average thickness of about $300 \mathrm{ft}$.

The lower Claiborne-upper Wilcox aquifer typically consists of massive sand beds; it directly overlies the middle Wilcox aquifer (table 1) and is present throughout an area of about $30,000 \mathrm{mi}^{2}$. The lower Claiborneupper Wilcox aquifer has an average thickness of about $360 \mathrm{ft}$ and is about 86 percent sand (table 2). The aquifer is more than 80 percent sand throughout most of its areal extent. The three areas where the unit contains between 60 and 80 percent sand total about $10,000 \mathrm{mi}^{2}$.
The largest of the three areas is in southern Texas and is about $7,000 \mathrm{mi}^{2}$; the smallest area is in northeastern Texas, northwest of the Sabine uplift, and is less than $1,000 \mathrm{mi}^{2}$. The third area is just east of the San Marcos arch and is about $2,000 \mathrm{mi}^{2}$.

The middle Wilcox aquifer overlies the Midway confining unit (table 1) and has an area of about 56,000 $\mathrm{mi}^{2}$. The aquifer typically is composed of thin alternating beds of sand and clay; it has an average thickness of about $1,800 \mathrm{ft}$ and has a sand content of about 55 percent (table 2). The aquifer contains more than 80 percent sand in one small area of a few hundred square miles west of the Sabine uplift. The aquifer everywhere contains more than 40 percent sand except for an area of about $3,000 \mathrm{mi}^{2}$ in southern Texas and a small area of a few hundred square miles near the Sabine uplift in eastern Texas.

\section{MISSISSIPPI EMBAYMENT AQUIFER SYSTEM}

The base of the Mississippi embayment aquifer system is the Midway confining unit except along a narrow band that is as much as $20 \mathrm{mi}$ wide across southern Louisiana where the top of the geopressured zone is the base of the aquifer system. In this band the geopressured zone is above the top of the sediments that compose the Midway confining unit (Grubb, 1986b). The confining unit has a maximum thickness of about 3,500 ft in Louisiana and an average thickness of about 750 to $850 \mathrm{ft}$. There are six aquifers and three confining units within the Mississippi embayment aquifer system (table 1, figs. 7, 12). The McNairy-Nacatoch aquifer, which underlies the Midway confining unit in the northern Mississippi embayment, was included in the Mississippi embayment aquifer system by Grubb (1984). However, results from simulation of groundwater flow in this aquifer indicate that only a small volume of water leaks upward from the McNairy-Nacatoch aquifer through the Midway confining unit and that the aquifer functions independently of the aquifers above the confining unit throughout most of its areal extent (Brahana, 1987).

Extensive and massive sand beds, especially in the updip and freshwater part of the system, are characteristic of the Mississippi embayment aquifer system. However, there is considerable variation among aquifers in the system. Some are separated by areally extensive confining units that restrict vertical movement of water. Other aquifers are not separated by areally extensive confining units but are defined on the basis of differences in lithology; the vertical resistance to flow within and between these aquifers is due to interbedded fine-grained sediments. 


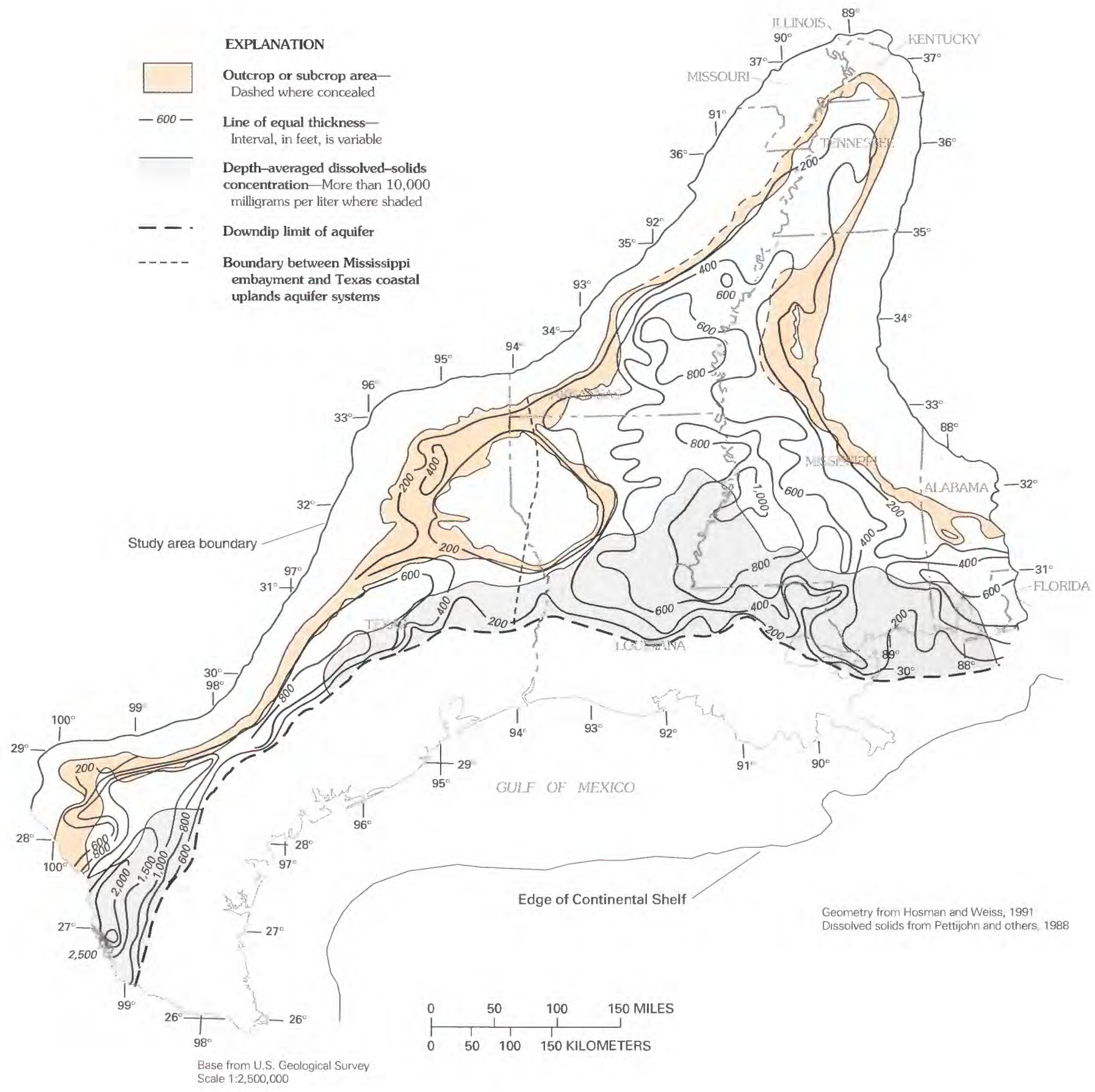

FIGURE 11 - Thickness of the middle Claiborne aquifer, Texas coastal uplands and Mississippi embayment aquifer systems. 


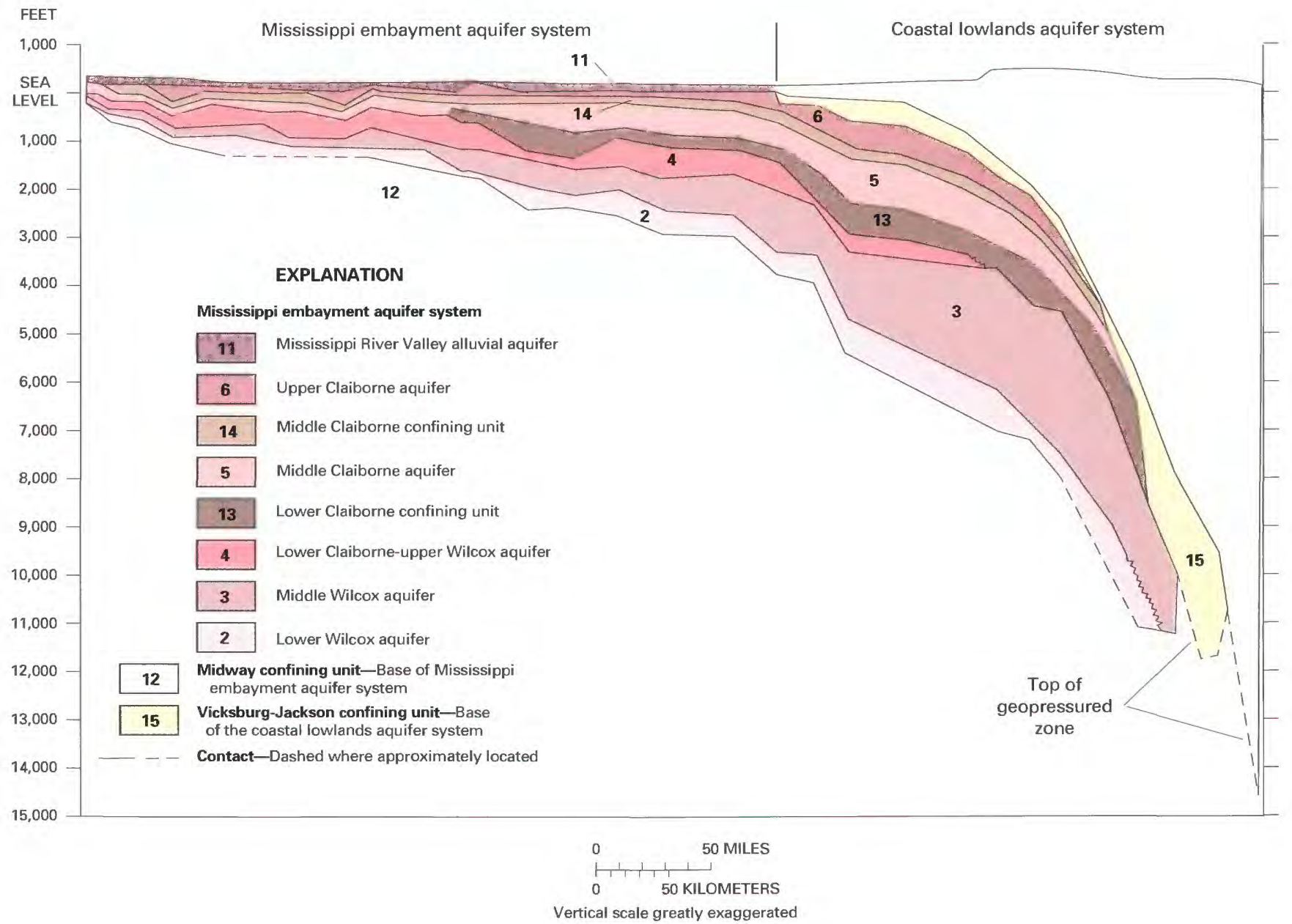

FIGURE 12.-Idealized section from near northern boundary of study area in Mississippi County, Missouri, to Iberville Parish, Louisiana, showing relation of geohydrologic units.

There are two aquifers in the Mississippi embayment aquifer system that are not present in the Texas coastal uplands aquifer system. These are the lower Wilcox aquifer and the Mississippi River Valley alluvial aquifer. The other aquifers of the Mississippi embayment aquifer system are laterally equivalent to aquifers present in the Texas coastal uplands aquifer system and they are called by the same names (table 1 ).

The Mississippi River Valley alluvial aquifer overlies aquifers and confining units in sediments of Tertiary age throughout an area of about $32,000 \mathrm{mi}^{2}$ in the northern Mississippi embayment, mostly in Missouri, Arkansas, northwestern Mississippi, and northeastern Louisiana (fig. 7). The aquifer has an average thickness of about $140 \mathrm{ft}$ and is about 70 percent sand (table 2). The aquifer is more than 80 percent sand throughout an elongate area of about $12,000 \mathrm{mi}^{2}$ from southern Illinois to west-central Mississippi.

The upper Claiborne aquifer overlies the middle Claiborne confining unit (table 1 ) and has an area of about $45,000 \mathrm{mi}^{2}$. The aquifer has an average thickness of about $300 \mathrm{ft}$ and contains about 52 percent sand (table 2). There are several isolated areas, extending from western Kentucky into central Mississippi, where the aquifer contains more than 80 percent sand. Except for one area of about $2,000 \mathrm{mi}^{2}$, which extends from south-central Arkansas into north-central Louisiana, these areas are only several hundreds of square miles in areal extent. The aquifer contains less than 20 percent sand in only two areas of a few hundred square miles in extent located in south-central Mississippi. The upper Claiborne aquifer is separated from the middle Clai- 
borne aquifer by the middle Claiborne confining unit, which has an average thickness of about $150 \mathrm{ft}$.

The middle Claiborne aquifer (fig. 11) typically consists of massive sand beds but has more fine-grained sediments than the underlying lower Claiborne-upper Wilcox aquifer. The middle Claiborne aquifer has an area of about $100,000 \mathrm{mi}^{2}$ and overlies the lower Claiborne confining unit (table 1) except for the area north of about $35^{\circ}$ latitude (figs. 7 and 12). The aquifer has an average thickness of about $490 \mathrm{ft}$ and is about 57 percent sand (table 2). The aquifer is more than 80 percent sand in an area of several tens of thousands of square miles in the northern Mississippi embayment. The middle Claiborne aquifer is less than 20 percent sand in two areas, each several thousand square miles in extent, located in southwestern Alabama, southern Mississippi, and southeastern Louisiana. As defined herein, the thickness of the aquifer north of about latitude $35^{\circ}$ north is less than that shown by Hosman and Weiss (1991). The difference is because about the lower onethird of this massive sand unit was included as an extension of the underlying lower Claiborne-upper Wilcox aquifer to facilitate the simulation of ground-water flow. This subdivision of the permeable units helps ensure that the hydraulic-head difference between aquifers is greater than that within the aquifers, especially in the vicinity of Memphis, Tenn., where large groundwater withdrawals have created considerable vertical hydraulic-head gradients (Weiss and Williamson, 1985).

The lower Claiborne-upper Wilcox aquifer typically consists of massive sand beds. It directly overlies the middle Wilcox aquifer (table 1) and has an area of about $80,000 \mathrm{mi}^{2}$. The lower Claiborne-upper Wilcox aquifer has an average thickness of about $270 \mathrm{ft}$ and is about 71 percent sand (table 2). The aquifer is more than 80 percent sand throughout an area of several tens of thousands of $\mathrm{mi}^{2}$ from western Kentucky to southwestern Arkansas. The aquifer is less than 20 percent sand only in a small area of about $1,000 \mathrm{mi}^{2}$ in southeastern Mississippi. This aquifer is overlain everywhere by the lower Claiborne confining unit except for an area of about $20,000 \mathrm{mi}^{2}$ north of about $35^{\circ}$ north latitude in the northern part of the Mississippi embayment. The confining unit has an average thickness of about $300 \mathrm{ft}$ where it is present in the Mississippi embayment aquifer system.

The middle Wilcox aquifer directly overlies the lower Wilcox aquifer (table 1 ) and has an area of about $110,000 \mathrm{mi}^{2}$. The aquifer typically consists of thin alternating beds of sand and clay; the aquifer has an average thickness of about $1,000 \mathrm{ft}$ and contains about 34 percent sand (table 2). The aquifer contains more than 80 percent sand in a small area of less than $1,000 \mathrm{mi}^{2}$ in the northernmost part of the Mississippi embayment. The aquifer contains less than 20 percent sand through- out an area of about $15,000 \mathrm{mi}^{2}$ in southeastern Mississippi and southwestern Alabama.

The lower Wilcox aquifer overlies the Midway confining unit (table 1) and has an area of about $104,000 \mathrm{mi}^{2}$. The aquifer has an average thickness of about $330 \mathrm{ft}$ and is about 67 percent sand (table 2). The aquifer is more than 80 percent sand throughout most of the northern part of the Mississippi embayment, but the sand content gradually decreases to the southeast where it is less than 40 percent throughout a large part of southern Mississippi.

\section{HYDRAULIC CONDUCTIVITY}

Much variability characterizes the permeability of aquifers and permeable zones in the study area, as indicated by hydraulic-conductivity data; however, hydraulic conductivity generally increases from west to east (Prudic, 1991). The geographic areas with the largest geometric mean horizontal hydraulic conductivity are centers of deposition by the ancestral Mississippi River. The most permeable aquifer is the Mississippi River Valley alluvial aquifer, which has a horizontal hydraulic conductivity of about $315 \mathrm{ft} / \mathrm{d}$ (fig. 13), whereas the middle Wilcox aquifer, the least permeable, has a horizontal hydraulic conductivity of only $20 \mathrm{ft} / \mathrm{d}$ (Prudic, 1991).

The variability of horizontal hydraulic conductivity among geographic areas, disregarding aquifers, is as great as that among aquifers (fig. 13). Prudic (1991) analyzed about 6,600 estimates of horizontal hydraulic conductivity and found statistically significant variability of the geometric mean among aquifers, geographic areas, and the combination of aquifer and geographic area. The values for horizontal hydraulic conductivity shown in figure 13 are not for the full thickness of the aquifer but more closely represent the horizontal hydraulic conductivity of individual sand beds or the more permeable parts of the aquifer.

To obtain estimates of horizontal hydraulic conductivity throughout the study area, values of sand percentage mapped by Hosman and Weiss (1991), and Weiss (1992) for each permeable zone or aquifer were multiplied by the geometric mean hydraulic conductivity of each geographic area in which the aquifer or permeable zone exists. The resulting areal distributions of regionalized horizontal hydraulic conductivity are shown in figures 33-36 and reflect all sand beds in the aquifer. Because the regional aquifers are rarely $\mathbf{1 0 0}$ percent sand throughout any extensive area, the estimates shown in figures 33-36 are smaller than the horizontal hydraulic-conductivity values shown in figure 13. The regionalized horizontal hydraulic conductivity 


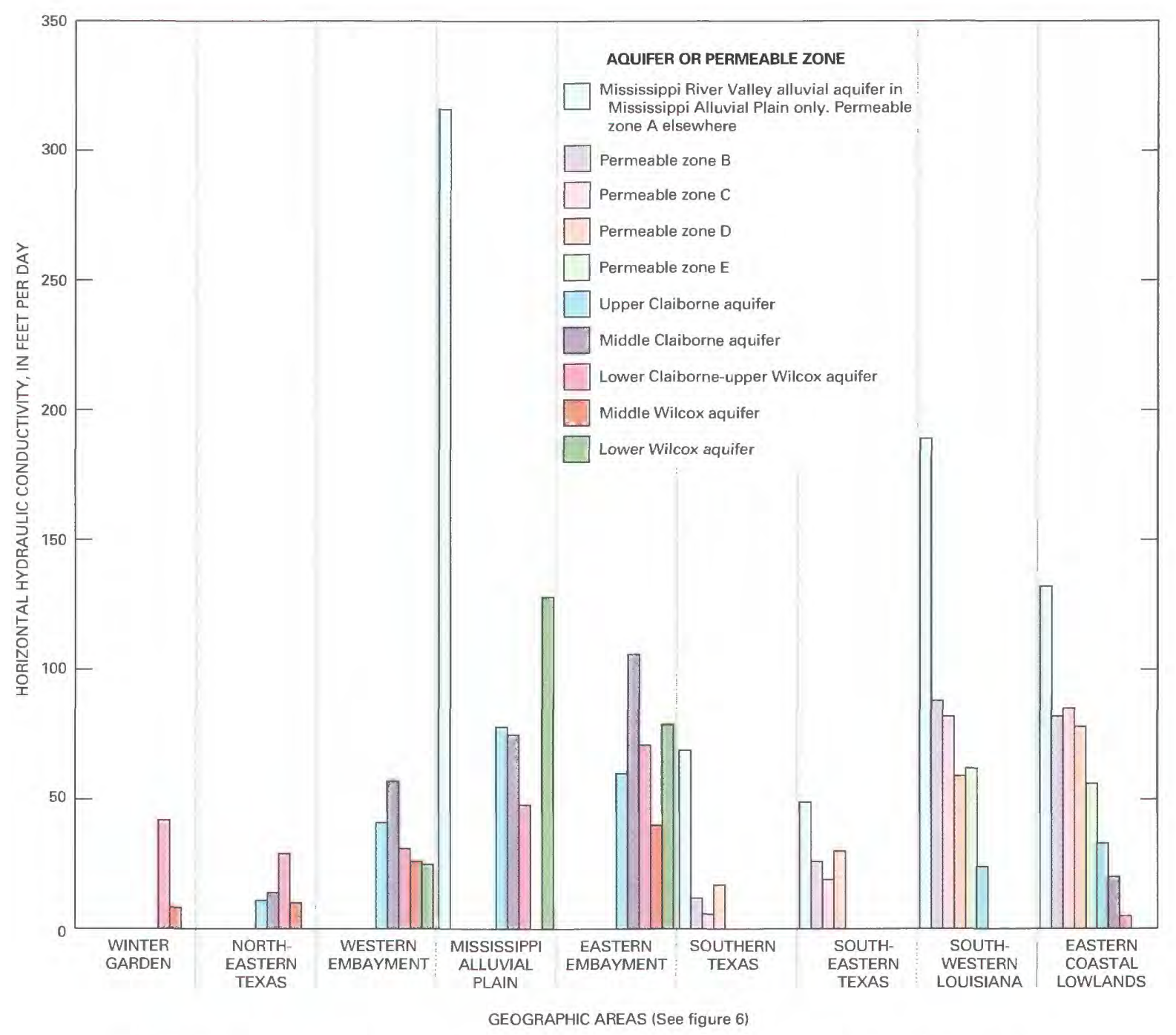

FIGURE 13.-Geometric mean horizontal hydraulic conductivity of aquifers and permeable zones by geographic area. (See figure 6 for location of geographic areas.)

values were the basis for transmissivities used in the regional ground-water flow simulations.

\section{GROUND-WATER CHEMISTRY}

The chemistry of water from permeable zones and aquifers of the gulf coast aquifer systems is highly variable as indicated by changes in dissolved-solids concentrations (Pettijohn and others, 1988), and water types (Pettijohn, Busby, and Beckman, 1992, 1993a, 1993b, 1993c; Pettijohn, Busby, and Cervantes, 1993a, 1993b, 1993c; Pettijohn, Busby, and Layman, 1993a, 1993b, 1993c). Several geochemical processes contribute to the observed variability in water chemistry, and the variability is significant with regard to water use and regional ground-water flow. Relatively little saline ground water is used in the study area (about
$210 \mathrm{Mgal} / \mathrm{d}$ during 1990), and only a relatively small part of each aquifer or permeable zone contains freshwater that is suitable for most uses.

\section{DISSOLVED-SOLIDS CONCENTRATIONS}

Water contained in the gulf coast aquifer systems is generally fresh in and near outcrop areas of the permeable zones and aquifers. Each permeable zone and aquifer in at least one area contains water with a dissolvedsolids concentration near that of precipitation or only a few tens of milligrams per liter. These areas of small concentrations of dissolved solids are typically in and near the aquifer outcrop area, and water samples are from shallow depths. In areas of several thousands of square miles, each permeable zone and aquifer contains water with dissolved-solids concentrations that range from a few tens of milligrams per liter to $500 \mathrm{mg} / \mathrm{L}$. 
Dissolved-solids concentrations in outcrop areas generally are less than $1,000 \mathrm{mg} / \mathrm{L}$, except for a few areas in southern Texas where the dissolved-solids concentrations of water range from about $1,000 \mathrm{mg} / \mathrm{L}$ to 3,000 $\mathrm{mg} / \mathrm{L}$ (Pettijohn and others, 1988).

Dissolved-solids concentrations in water from all aquifers and permeable zones generally increase toward the Gulf of Mexico and toward principal discharge areas. Dissolved-solids concentrations typically increase from 10,000 to $35,000 \mathrm{mg} / \mathrm{L}$ over distances of 10 to $40 \mathrm{mi}$. The deeper parts of the permeable zones and aquifers contain brine with dissolved-solids concentrations that typically exceed that of seawater by as much as a factor of 2 . Each permeable zone and aquifer underlies at least one area of several tens of square miles where the water has a dissolved-solids concentration that ranges from 70,000 to $150,000 \mathrm{mg} / \mathrm{L}$. Exceptions are the Mississippi River Valley alluvial aquifer, which is exposed at land surface throughout its areal extent, and permeable zone A, which is also at land surface throughout its onshore extent. In contrast, throughout thousands of square miles, permeable zones C, D, and $\mathrm{E}$ contain water with dissolved-solids concentrations that range from 70,000 to $150,000 \mathrm{mg} / \mathrm{L}$. Permeable zones C, D, and E typically are buried beneath several thousand feet of sediments in the areas having large dissolved-solids concentrations.

The aquifers of the Mississippi embayment aquifer system contain freshwater throughout a greater geographic area than the aquifers in the Texas coastal uplands aquifer system. This is primarily because of a greater areal extent of the aquifers updip from the Vicksburg-Jackson confining unit in the Mississippi embayment aquifer system, and perhaps secondarily because of much less rainfall in the western part of the study area than in the eastern part. The permeable zones of the coastal lowlands aquifer system in southern Texas have only small areas of a few hundred square miles where they contain water with dissolvedsolids concentrations less than $1,000 \mathrm{mg} / \mathrm{L}$. East of the Brazos River in Texas, most of the permeable zones contain freshwater, or water with dissolved-solids concentrations less than $1,000 \mathrm{mg} / \mathrm{L}$, throughout thousands of square miles.

\section{WATER TYPES}

The water type in and near aquifer outcrop areas typically is calcium bicarbonate or calcium bicarbonate and sodium bicarbonate; locally, other water types are present. The water type is dominantly sodium bicarbonate in middip areas of the aquifers. The dominant water type typically is sodium chloride near the downdip limit of the aquifers and permeable zones. The vari- ability of water type is demonstrated by the areal distribution of water types in permeable zone B of the coastal lowlands aquifer system (fig. 14) and the middle Claiborne aquifer of the Texas coastal uplands and Mississippi embayment aquifer system (fig. 15).

The dominant water type is sodium bicarbonate in the outcrop area of permeable zone B across Mississippi and Louisiana (fig. 14). The dominant water types in outcrop areas of the permeable zone are calcium bicarbonate in southeastern Texas and sodium chloride in southern Texas. Sodium bicarbonate is the dominant water type downdip from the outcrop area of permeable zone B throughout several thousands of square miles in Mississippi and Louisiana. About midway between the area of outcrop and the downdip limit of the permeable zone across southern Louisiana, sodium chloride is the dominant water type. Permeable zone B contains several water types downdip from the outcrop area in Texas, commonly calcium bicarbonate and sodium bicarbonate in southeastern Texas and sodium chloride in southern Texas.

Several water types are present in the outcrop area of the middle Claiborne aquifer (fig. 15). The aquifer typically contains calcium bicarbonate and sodium bicarbonate water types in outcrop areas of the Mississippi embayment aquifer system. Sodium sulfate and sodium chloride water types are common in addition to calcium bicarbonate and sodium bicarbonate where the aquifer outcrops as part of the Texas coastal uplands aquifer system. Sodium bicarbonate is the dominant water type downdip from the outcrop area of the aquifer in the Mississippi embayment aquifer system except in southern Mississippi, where sodium chloride is the dominant water type. Sodium bicarbonate is the dominant water type downdip from the aquifer outcrop area in southeastern Texas, but in southern Texas the aquifer contains sodium bicarbonate, sodium chloride, and sodium sulfate water types. Sodium chloride is the dominant water type at all locations near the downdip limit of the aquifer.

\section{GEOCHEMICAL PROCESSES}

A variety of geochemical processes affect the water chemistry in the gulf coast aquifer systems. The major postulated processes are (1) leaching of soluble salts from the unsaturated zone, (2) alteration of albite, (3) cation exchange, (4) mixing of water by the vertical flow of water from underlying units, and (5) the dissolution of halite from salt diapirs (Pettijohn, 1996). The leaching of soluble salts from the unsaturated zone is a process that is limited to the outcrop area of permeable zones and aquifers. The alteration of albite typi- 


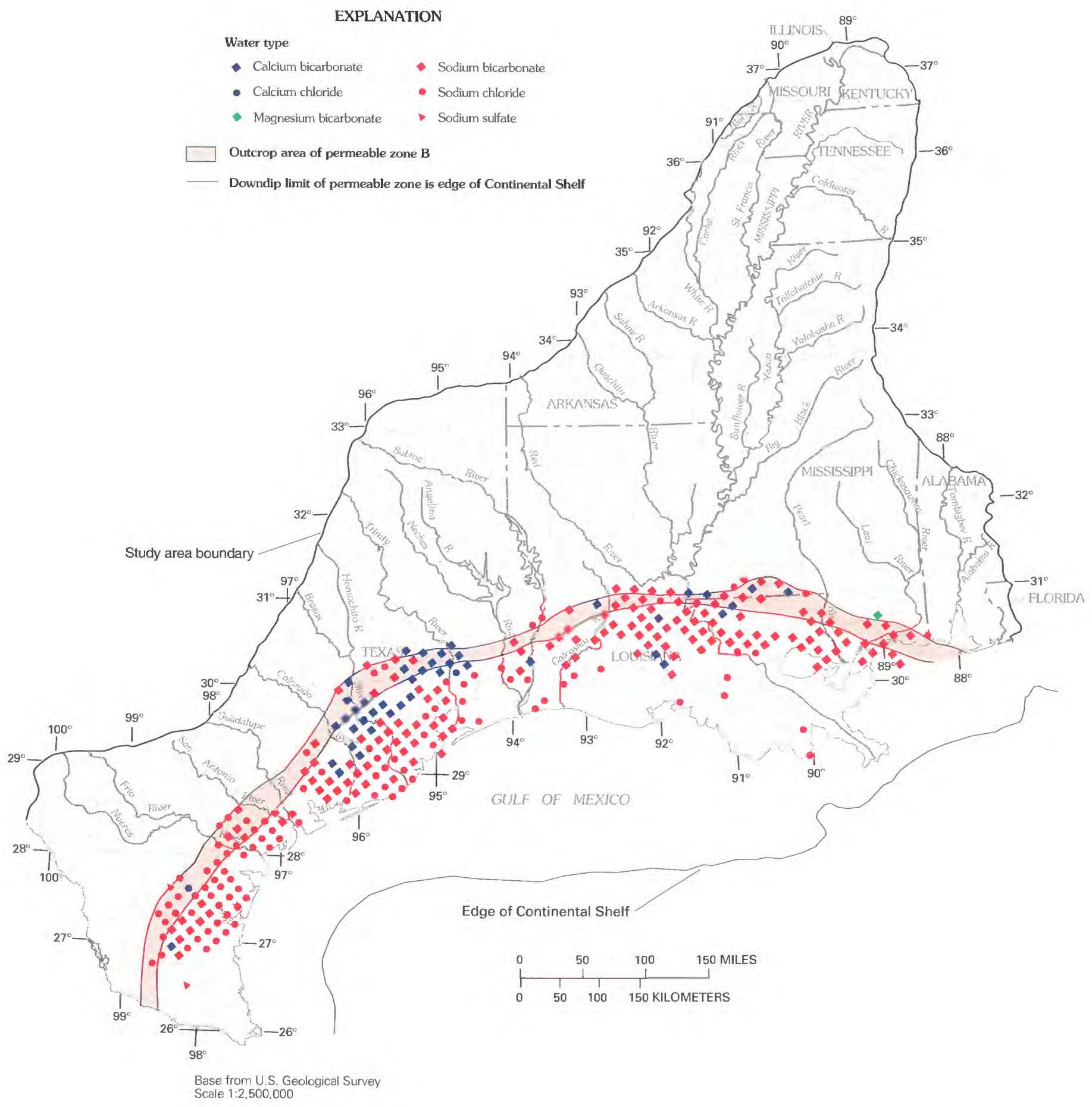

FIGURE 14.-Dominant water types in permeable zone B (lower Pleistocene-upper Pliocene deposits), coastal lowlands aquifer system. 


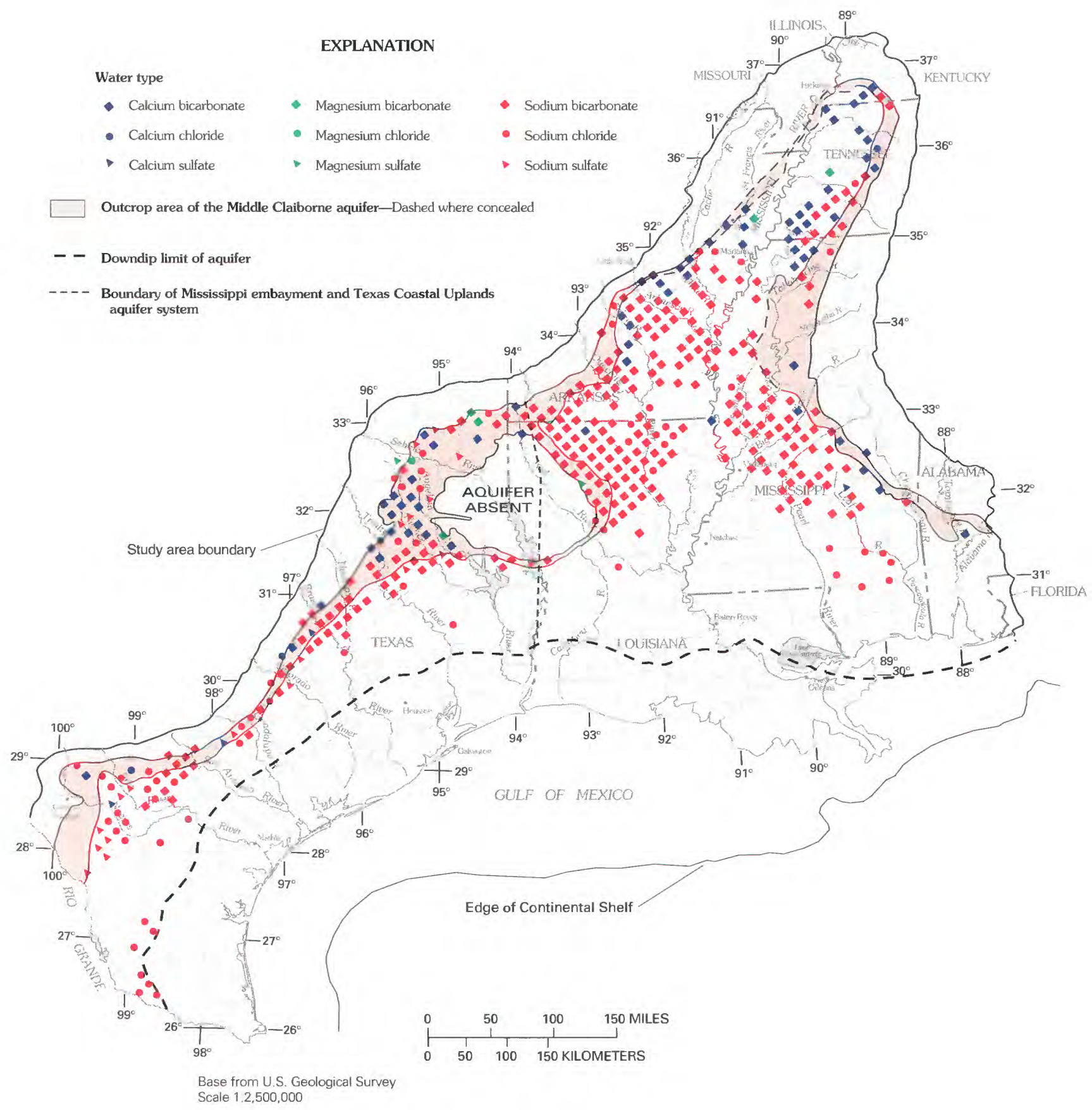

FiGURE 15.-Dominant water types in the middle Claiborne aquifer. Texas coastal uplands and Mississippi embayment aquifer systems. 
cally is an important process downdip from the outcrop area of a permeable zone or aquifer throughout several thousands of square miles; alteration of albite may also be important near the downdip limit of the outcrop area if the permeable zone or aquifer is thick. Cation exchange is important in permeable zones and aquifers when water with moderately large concentrations of calcium comes in contact with interbedded clays that have exchange sites saturated with sodium. Vertical flow upward from underlying permeable zones or aquifers becomes an important process when the dissolvedsolids concentration of water in the underlying unit is much larger than that of water in the receiving permeable zone or aquifer, and the volume of vertical flow is 10 percent or more of the volume of horizontal flow. The dissolution of halite is an important process in areas where salt diapirs penetrate a permeable zone or aquifer at depths greater than $4,000 \mathrm{ft}$. At shallow depths (less than about 4,000 ft in the Gulf Coastal Plain) salt diapirs commonly are sealed by a relatively impervious cap rock derived from an accumulation of insoluble residues precipitated from ground water acting on the diapir's salt mass (Halbouty, 1979) in the geologic past; therefore; currently, dissolution of halite is minimal.

The major geochemical processes leave a typical imprint on the water, either increasing or decreasing certain ions or groups of ions. The leaching of soluble salts from the unsaturated zone results in an increase in the concentration of most major chemical ions. The alteration of albite results in an increase in sodium and bicarbonate ions and an increase in $\mathrm{pH}$. Cation exchange results in the removal of the calcium ion from solution and the addition of the sodium ion as calcium replaces sodium on the clay colloids. The mixing of water that moves from an underlying aquifer or permeable zone with water moving horizontally in the receiving permeable zone or aquifer results primarily in an increase in the sodium and chloride ion because water in deeper sediments typically have larger concentrations of sodium and chloride. The dissolution of halite from salt diapirs results in an increase in the concentration of the sodium and chloride ion because the principal component of the salt diapirs is sodium chloride.

\section{HISTORY OF GROUND-WATER DEVELOPMENT}

Ground-water withdrawals for cities or for agricultural use began during the late 1800's at many locations in the Gulf Coastal Plain. By 1900 the city of Memphis, Tennessee, was withdrawing about $30 \mathrm{Mgal} / \mathrm{d}$ and
Houston, Texas, was withdrawing about $20 \mathrm{Mgal} / \mathrm{d}$. Withdrawal of ground water for irrigation of rice began west of Houston during the 1890's and in southwestern Louisiana and central Arkansas in the early 1900's. Pumpage has continued to increase at uneven rates throughout the Coastal Plain. Increases in population, development and growth of industry, and expansion of irrigated agriculture have been the primary factors contributing to increases in ground-water withdrawals. The following discussion will focus briefly on trends in ground-water withdrawals from the perspective of the total study area and individual aquifer systems, then shift to a more detailed look at trends for four cities and for three areas with large-scale irrigated agriculture. These four cities and three irrigated areas accounted for about 80 percent of the ground water withdrawn in the study area during 1985.

Estimates of ground-water withdrawals for the entire study area have been compiled for the period 1960-90, at 5-year intervals. Withdrawals during 1960 were about 4,000 Mgal/d and increased steadily to almost 10,000 Mgal/d during 1980 (fig. 16). Withdrawals decreased about 7 percent from 1980 to 1985 , and increased about 20 percent (to about $10,900 \mathrm{Mgal} / \mathrm{d}$ ) from 1985 to 1990 . The quantity of ground water withdrawn for public supply increased continually from 1960 to 1990 , whereas ground-water withdrawals for industrial purposes decreased continually from 1975 to 1985 but increased slightly by 1990 . Withdrawals for irrigation increased by a factor of about 3 during the period 1960-80, increasing from 2,200 to 7,200 Mgal/d.

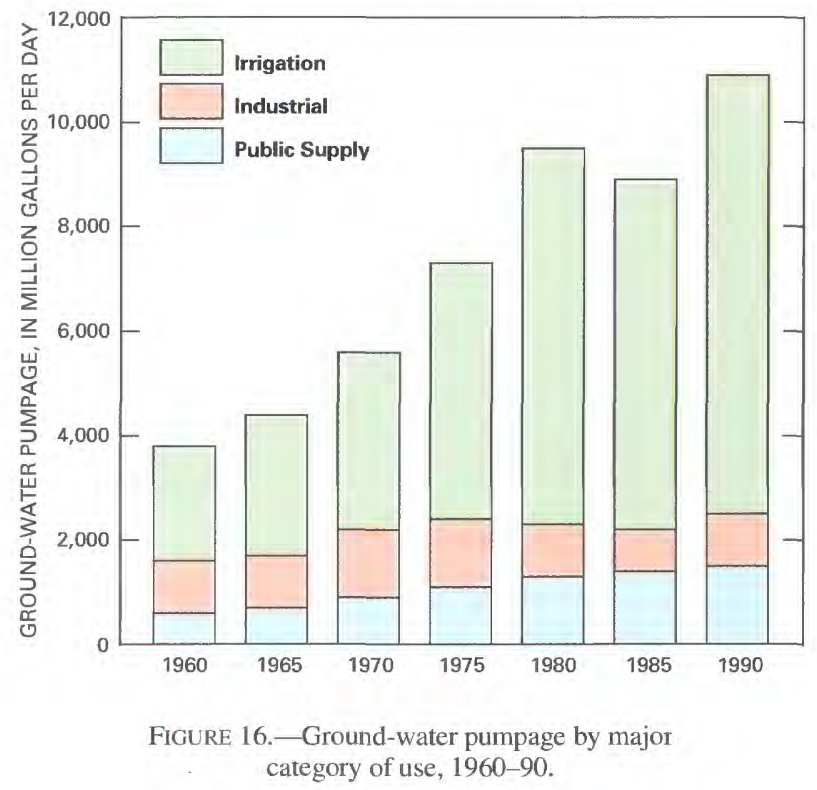


However, irrigation withdrawals decreased about 7 percent from 1980 to 1985 but increased again from 1985 to 1990 , reaching about $8,400 \mathrm{Mgal} / \mathrm{d}$.
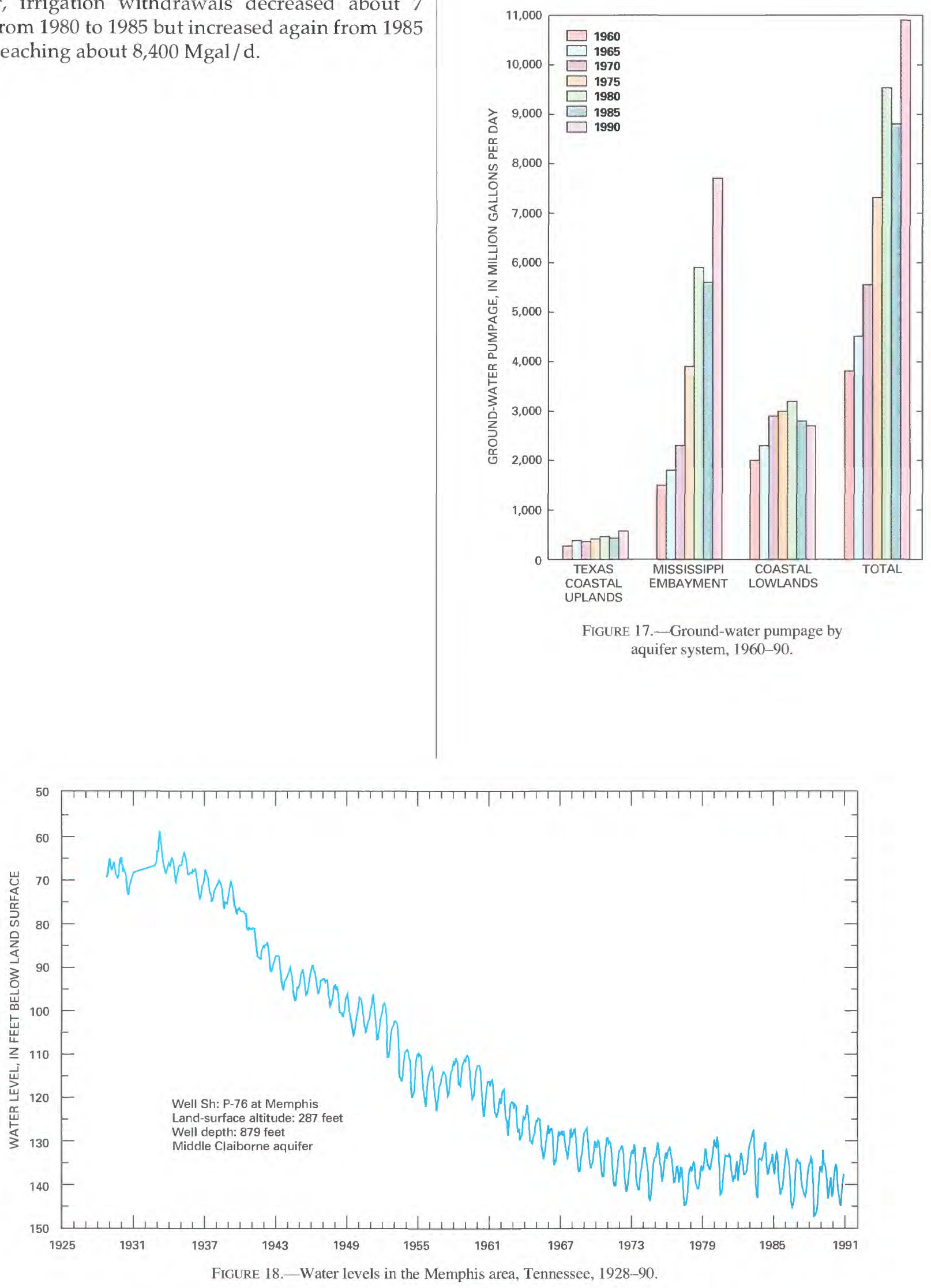
The distribution of ground-water withdrawals among aquifer systems is shown in figure 17. Of the three aquifer systems, the Mississippi embayment aquifer system supplied the most ground water for all uses during the period 1975-90. However, during the period 1960-70 the largest ground-water withdrawals were from the coastal lowlands aquifer system (fig. 17). Withdrawals from the Texas coastal uplands aquifer system were the least for the period 1960-90, ranging from 270 to $460 \mathrm{Mgal} / \mathrm{d}$. Withdrawals during the period 1960-90 increased the least from the Texas coastal uplands aqui- fer system and increased the most from the Mississippi embayment aquifer system.

\section{MEMPHIS}

The trends in ground-water withdrawals in the Memphis area, Tennessee, are related to growth in population and development of industry. Ground-water withdrawals at Memphis were about $30 \mathrm{Mgal} / \mathrm{d}$ from 1895 to 1920 and then began to increase at a rate of about $2 \mathrm{Mgal} / \mathrm{d}$ per year until about 1940. Beginning in 1946, pumpage at Memphis increased at a rate of about
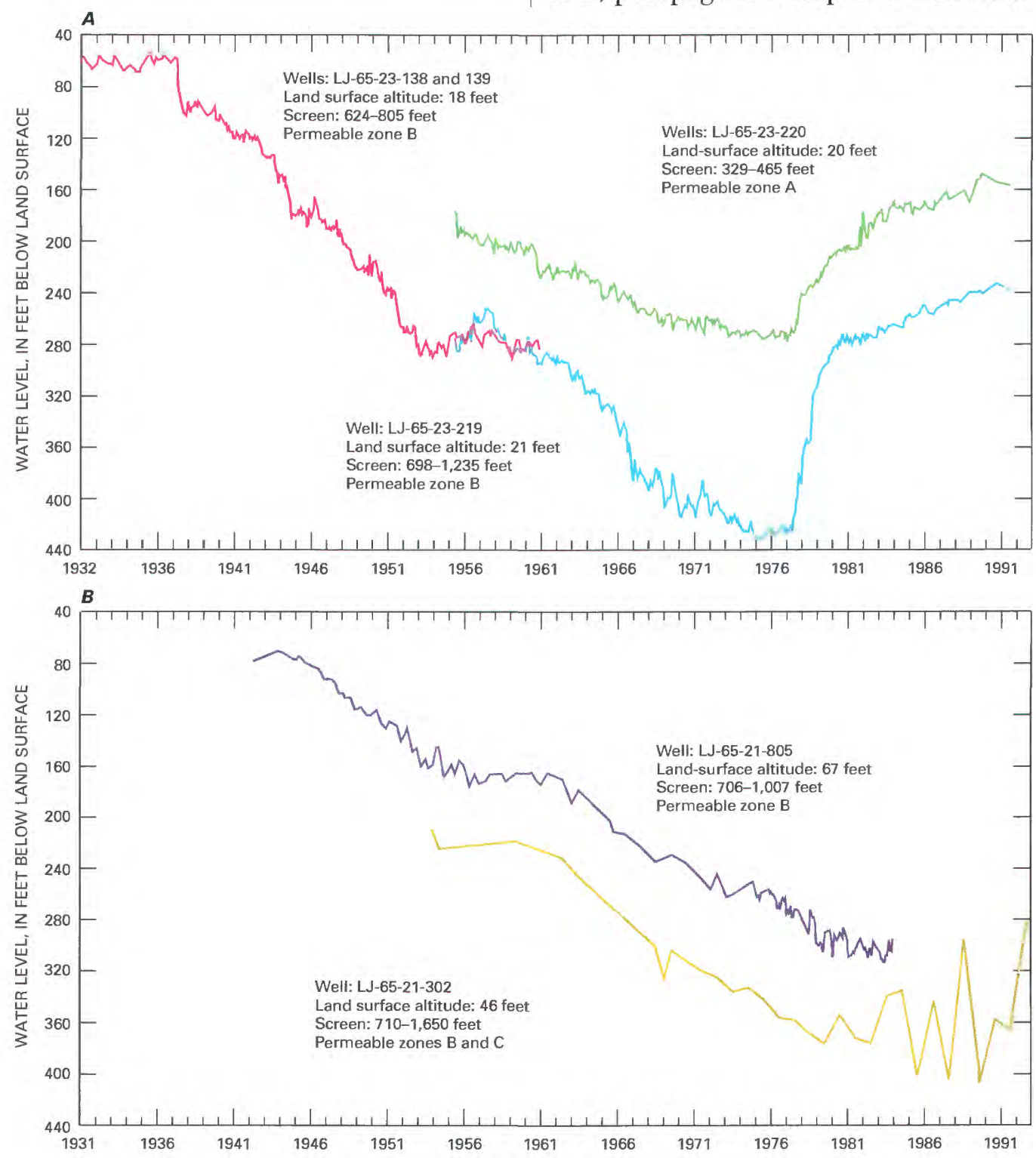

FIGURE 19.-Water levels in the Houston area, Texas, 1932-92. 
$4 \mathrm{Mgal} / \mathrm{d}$ per year until 1974, at which time rates stabilized at between 190 and $200 \mathrm{Mgal} / \mathrm{d}$ (Criner and Parks, 1976) and remained in that range through 1990. Thus, water levels that continuously declined as much as $70 \mathrm{ft}$ from 1934 to 1974 have stabilized near the center of pumping and have fluctuated about $15 \mathrm{ft}$ seasonally since the mid-1970's (fig. 18).

\section{HOUSTON}

Trends in ground-water withdrawals in the Houston area, Texas, are related to population growth, development and growth of industry, replacement of ground water by surface water in some industrial parts of the area, and a shift from irrigated agriculture to public supply as a result of urban expansion. Ground-water withdrawals more than doubled every 20 years in the Houston area from 1900 to 1960 (Wood and Gabrysch, 1965). By 1985, the combined pumpage from Galveston and Harris Counties (includes Houston) was about $390 \mathrm{Mgal} / \mathrm{d}$ (Mesko, and others, 1990). Until 1954, ground water was the sole source of water for the city of Houston. At that time, surface water was introduced from the San Jacinto River, beginning with about $1 \mathrm{Mgal} / \mathrm{d}$ in 1954 and increasing to 24-

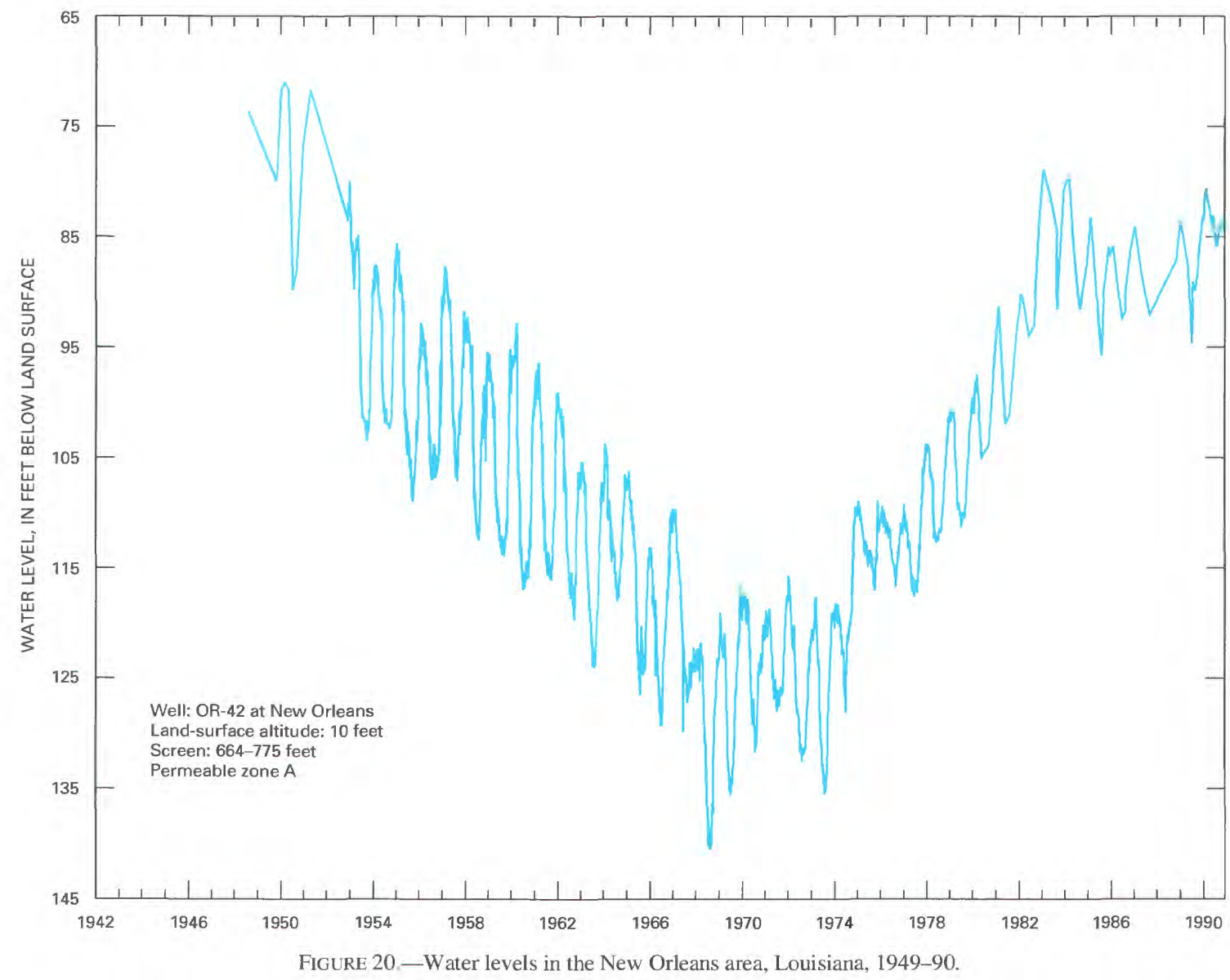


$29 \mathrm{Mgal} / \mathrm{d}$ by 1967 . Since 1968, use of surface water has increased periodically and ground-water withdrawals have decreased in the industrial district of Houston. Water levels stabilized in 1973 and began to recover in 1977 (fig. 19A) as a result of decreased withdrawals. However, ground-water withdrawals have continued to increase because of urban development to the north and west of Houston. Thus, water levels in these areas continued to decline until as recently as 1989 (fig. 19B).

\section{NEW ORLEANS}

Trends in ground-water withdrawals in the New Orleans area, Louisiana, reflect, almost exclusively, changes in industrial water use. During 1990, about 65 percent of the ground-water withdrawn was used in the generation of electricity. The withdrawal of ground water in the New Orleans area began as early as the mid-1800's with the drilling of the "Canal Street" well in 1854, and many other wells were drilled in the late 1800 's and early 1900's (Harris, 1904). The water has been used mostly by industries because the most pro- ductive sands yield water that has a yellow color. Based on few data, Rollo (1966) estimated that ground-water withdrawals were about $5 \mathrm{Mgal} / \mathrm{d}$ by 1900 and increased at an annual rate of about $0.5 \mathrm{Mgal} / \mathrm{d}$ until 1955 when pumpage was about $35 \mathrm{Mgal} / \mathrm{d}$. Withdrawals increased at an annual rate of about $1.5 \mathrm{Mgal} / \mathrm{d}$ from 1955 to 1970 when pumpage was about $55 \mathrm{Mgal} / \mathrm{d}$. Withdrawals decreased from 1970 at an annual rate of slightly more than $1 \mathrm{Mgal} / \mathrm{d}$ to 1990 when pumpage was about $33 \mathrm{Mgal} / \mathrm{d}$. Thus water levels near the center of pumping declined for a long period of time and then recovered during the late 1970's to levels observed during the 1950's (fig. 20).

\section{BATON ROUGE}

Trends in ground-water withdrawals in the Baton Rouge area, Louisiana, reflect growth in population and industry and a shift in pumpage from shallower to greater depths as demand for water increased. Large withdrawals of ground-water began

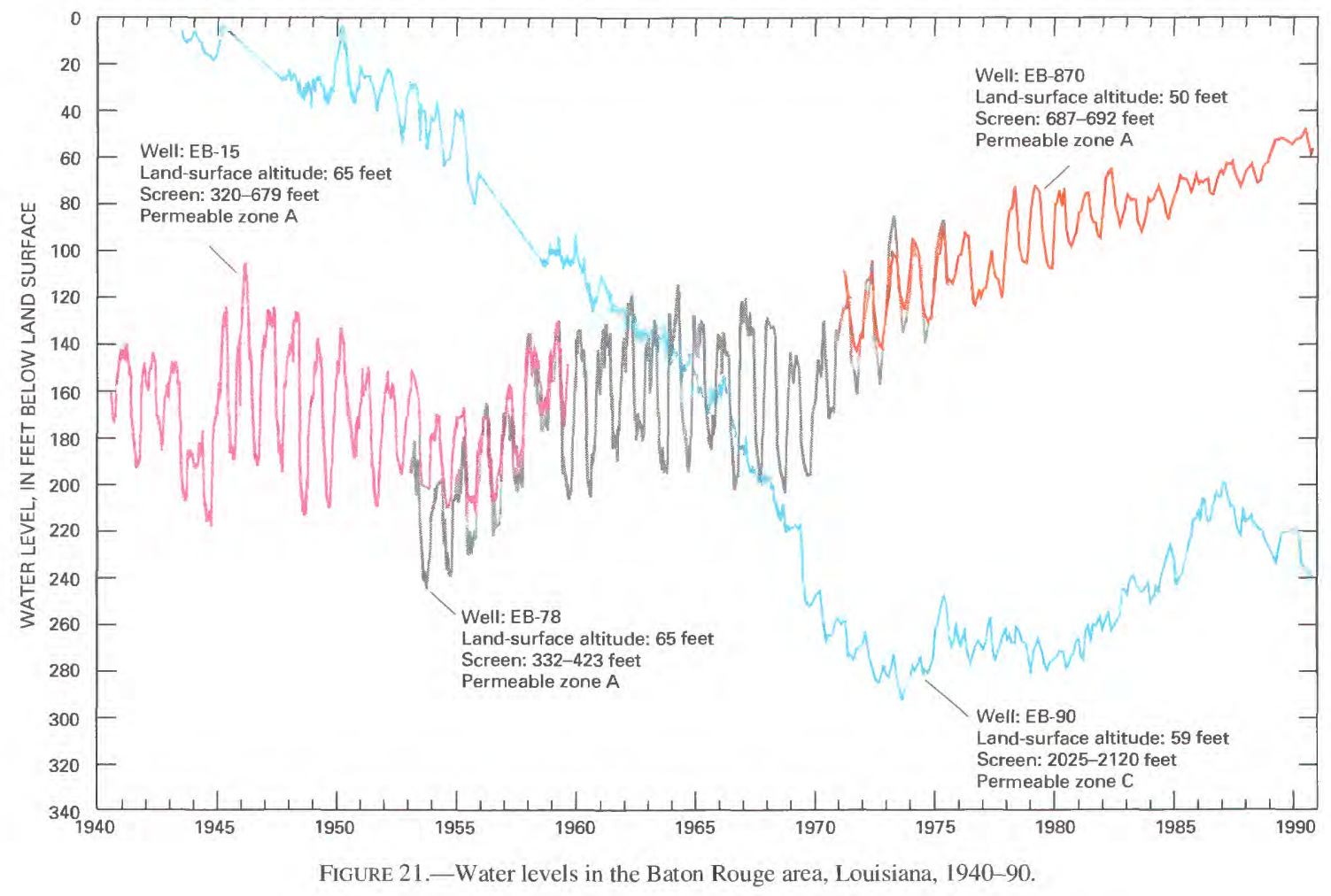


in the Baton Rouge area with the construction of a well drilled for public supply in 1892 (Harris, 1904), and withdrawals were estimated at $2 \mathrm{Mgal} / \mathrm{d}$ by 1900 (Meyer and Turcan, 1955). Withdrawals increased to an estimated $10 \mathrm{Mgal} / \mathrm{d}$ by 1920 . Three periods of rapidly increasing withdrawals, 1930-40, 1950-55, and $1965-70$, resulted in an increase in pumpage from about $12 \mathrm{Mgal} / \mathrm{d}$ in the 1930 's to $140 \mathrm{Mgal} / \mathrm{d}$ during 1970. Since 1970, pumpage has varied between 120 and 150 $\mathrm{Mgal} / \mathrm{d}$. An increasingly larger percentage of pumpage shifted from the shallower sands to the deeper sands since 1950; thus, water-level declines in the shallower sands of permeable zone A have recovered to levels existing prior to the 1940 's, as indicated by the water levels shown in figure 21.

\section{MISSISSIPPI ALLUVIAL PLAIN}

Trends in ground-water withdrawals in the Mississippi Alluvial Plain mostly reflect an increase in irrigation of rice, although about 5 percent of the volume withdrawn during the 1980's was for industry and public supply and an increasing volume has been withdrawn for aquaculture or fish farming. The withdrawal of large quantities of ground water for the irrigation of rice in the Mississippi Alluvial Plain north of about Natchez, Mississippi, followed the successful planting and harvesting of 80 acres of rice in Lonoke County, Arkansas, during 1904 (Stephenson and Crider, 1916). By 1910, about $75 \mathrm{Mgal} / \mathrm{d}$ was withdrawn from the Mississippi River Valley alluvial aquifer for the irrigation of rice in Arkansas (Engler and others, 1963). The
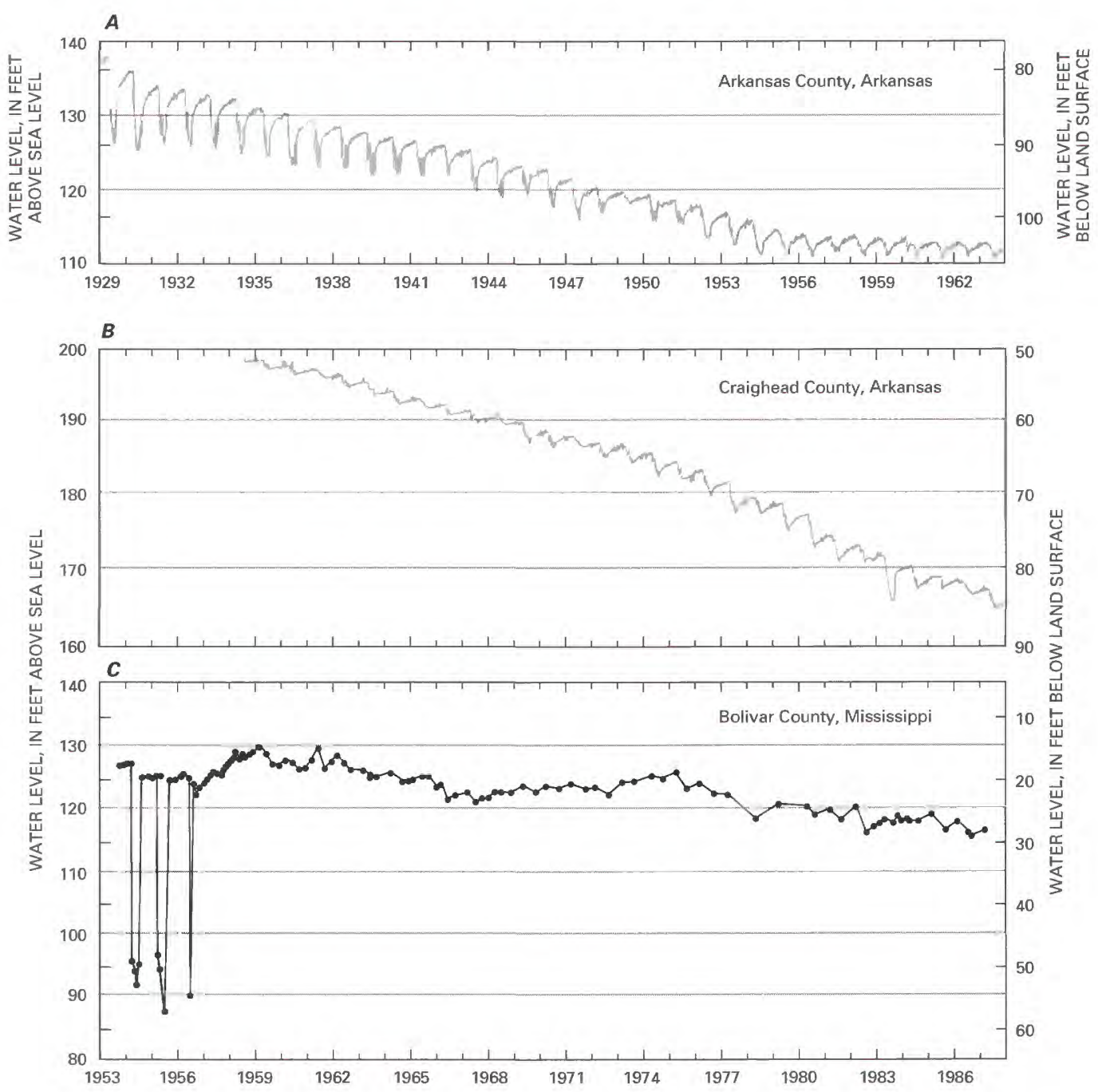

FIGURE 22.-Water levels in the Mississippi Alluvial Plain, 1929-87. 
average annual withdrawal was about $180 \mathrm{Mgal} / \mathrm{d}$ from 1912 through 1941. In 1942, when the first of two periods of rapid increase in ground-water use for rice irrigation began, withdrawals increased annually at about $70 \mathrm{Mgal} / \mathrm{d}$ until 1954, then remained relatively constant at about $1,600 \mathrm{Mgal} / \mathrm{d}$ until the early 1970's. It was during this period of rapid increases in rice acreage, and consequently increasing ground-water withdrawals, that rice began to become an important crop in States underlain by the Mississippi River Valley alluvial aquifer adjacent to Arkansas. Withdrawals increased annually at about $340 \mathrm{Mgal} / \mathrm{d}$ from the early 1970's to the early 1980's during the second period of rapid increase in ground-water use for irrigation of rice. Withdrawals have continued at about 5,000 Mgal/d from the early 1980's through 1990. Thus, water levels near the center of the early withdrawals in Arkansas declined over the years until they stabilized in the midto late 1950's and have fluctuated about $5 \mathrm{ft}$ seasonally since about the mid-1950's (fig. 22A). In other areas, declines have continued as ground-water was withdrawn to support the expansion of rice acreage (fig. $22 B, C)$. A decrease in saturated thickness of $30 \mathrm{ft}$ or more has occurred in eastern and central Arkansas (Ackerman, 1996).

\section{SOUTHWESTERN LOUISIANA}

Trends in ground-water withdrawals in southwestern Louisiana reflect growth in population and the irrigation of rice and large increases in industrial use up to the mid-1970's followed by reductions in industrial use of ground water. Several hundred wells were used to withdraw ground water for the irrigation

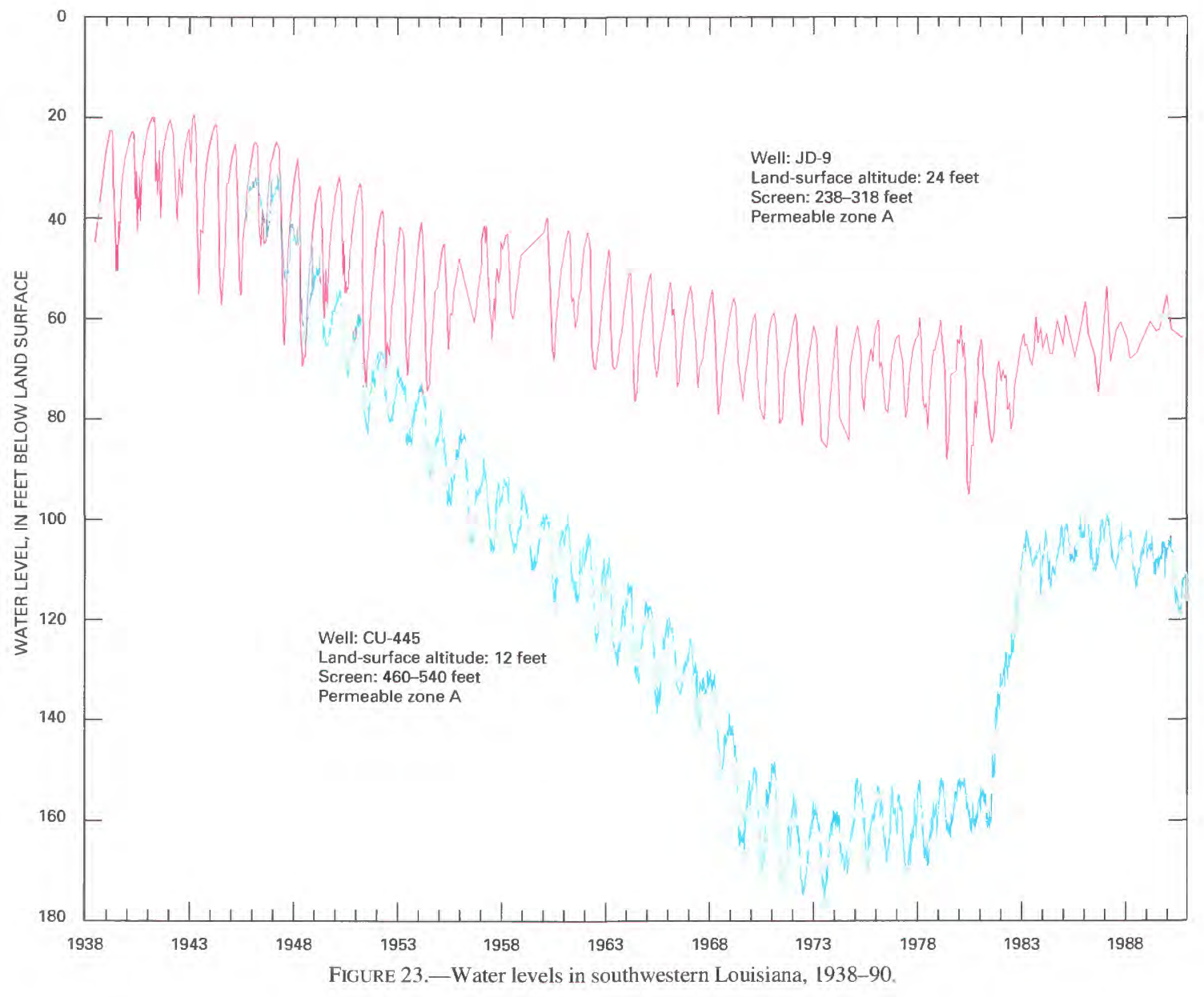


of rice in southwestern Louisiana by 1903 (Fuller, 1904), but no estimate was made of the quantity withdrawn. During the early 1900 's, about 300,000 acres of rice were cultivated in southwestern Louisiana; by 1946 about 600,000 acres of rice were cultivated, and about 240,000 acres were irrigated with ground water (Jones and others, 1956). The quantity of ground water withdrawn during 1947 for rice irrigation was about $280 \mathrm{Mgal} / \mathrm{d}$ (Jones and others, 1956); this quantity had increased to about $800 \mathrm{Mgal} / \mathrm{d}$ by 1980 (Mesko and others, 1990). Withdrawals for irrigation averaged about $450 \mathrm{Mgal} / \mathrm{d}$ for the period 1952-61 and about $670 \mathrm{Mgal} / \mathrm{d}$ for the period 1962-90. About $100 \mathrm{Mgal} / \mathrm{d}$ of ground water was withdrawn during 1947 for other uses, such as public supply and industry, and this quantity increased to about $300 \mathrm{Mgal} / \mathrm{d}$ by 1975. Ground water withdrawn for industrial use decreased about 50 percent from 1975 to 1985. Total ground-water withdrawals decreased from about 1,100 Mgal/d during 1980 to about $810 \mathrm{Mgal} / \mathrm{d}$ during 1990. Thus, water levels near the centers of pumping for industrial use (well CU-445, fig. 23) show a long-term decline until about 1970 when they became relatively stable. Water levels recovered substantially during 1982 and remained relatively stable through 1990. Water-level changes were much less dramatic at locations remote from the centers of pumping for industrial use (well JD-9, fig. 23). The decrease in total ground-water withdrawals for 1980-90 may be the beginning of a reversal in the trend of increasing withdrawals that began early in the 20th century. However, many factors affect ground-water withdrawals, especially ground water used for irrigation. For example, during 1951 (a period of less than normal rainfall in southwestern Louisiana) about $70 \mathrm{Mgal} / \mathrm{d}$ more ground water was withdrawn than in 1985 , a period of nearly normal rainfall.

\section{WINTER GARDEN}

Trends in ground-water withdrawals in the Winter Garden area, Texas, are mostly related to two periods of growth in irrigation, largely of vegetable crops, and recent fluctuations related to weather, and perhaps to economic conditions. Ground-water withdrawals for irrigation in the Winter Garden area began with the completion of the first flowing well at Carrizo Springs, Texas, in 1884 (Turner and others, 1960). The quantity

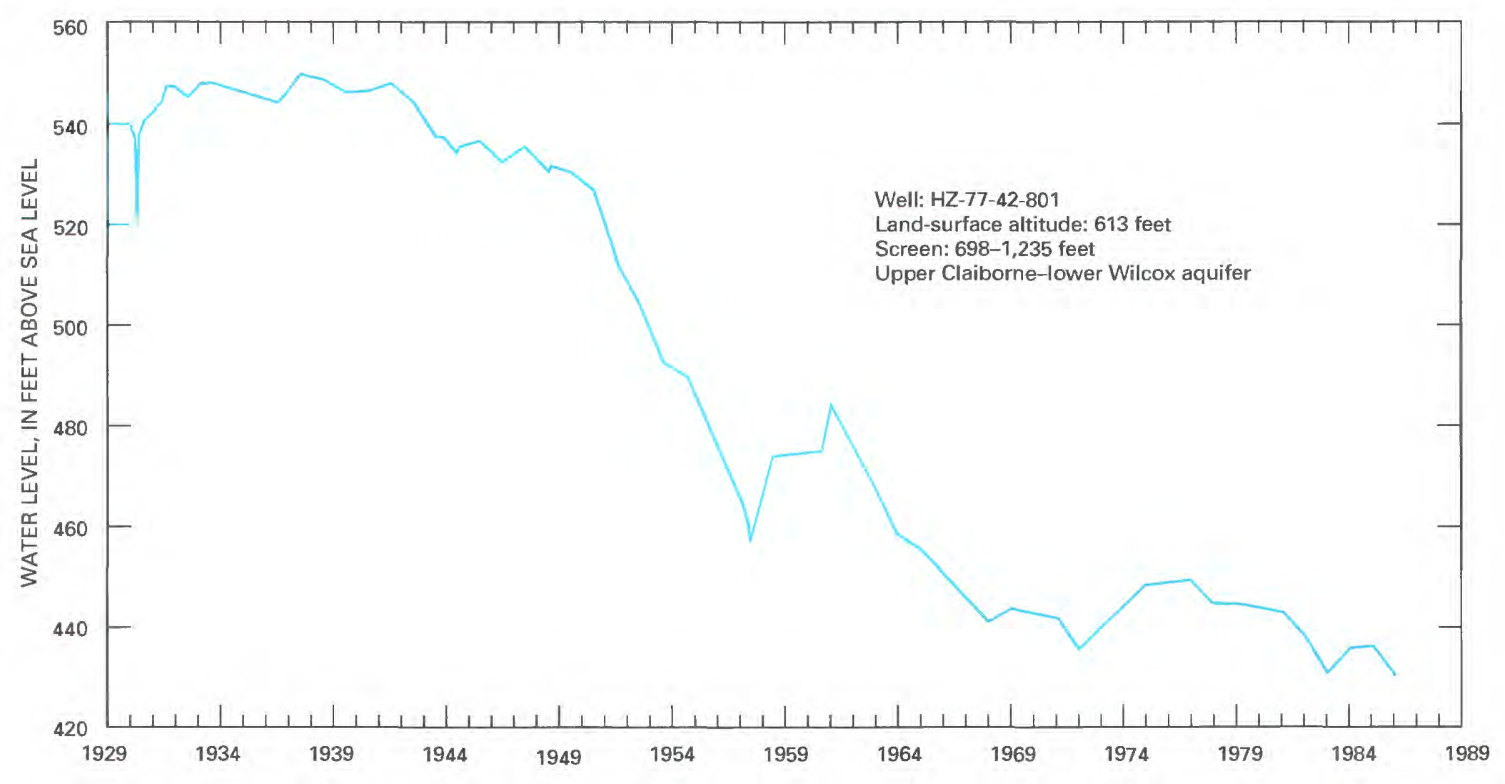

Figure 24.-Water levels in the Winter Garden area, Texas, 1929-86. 
of water withdrawn throughout the first three decades of the 20th century probably increased, based on the reported increase in the number of wells (Taylor, 1907). However, no estimates of total use were available until about 1930, when about $36 \mathrm{Mgal} / \mathrm{d}$ was withdrawn for irrigation, public supply, and industrial use (Sundstrom and Follett, 1950; Turner and others, 1960). Withdrawals increased to about $80 \mathrm{Mgal} / \mathrm{d}$ by 1950 and to about $230 \mathrm{Mgal} / \mathrm{d}$ by 1965. Since 1965, withdrawals have varied between 220 and $280 \mathrm{Mgal} / \mathrm{d}$. Thus, water levels near the center of pumping show a long-term decline until the late 1960's and a relatively stable period for 1965-90 (fig. 24). Water levels in and near the aquifer outcrop area are still declining and may continue to do so for many years.

\section{REGIONAL GROUND-WATER FLOW}

Regional ground-water flow patterns have been changed greatly by the withdrawal of large quantities of ground water. These changes are best demonstrated by comparison of the results from several simulations of ground-water flow. Thus, most of the following discussion is summarized from several ground-water flow simulations that were done as part of the Gulf Coast RASA study and reported by Ackerman (1989a, 1996), Arthur and Taylor (1990; in press), Brahana and Mesko (1988; in press), Martin and Whiteman (1989; in press), Ryder (1988), Ryder and Ardis (in press), Williamson and others (1990), and Williamson and Grubb (in press). Few data are available to define the areal distribution of the potentiometric surfaces of the aquifers and permeable zones prior to development (that is prior to withdrawal of substantial quantities of ground water, also referred to herein as predevelopment). Therefore, predevelopment potentiometric surfaces were simulated

\section{EXPLANATION}

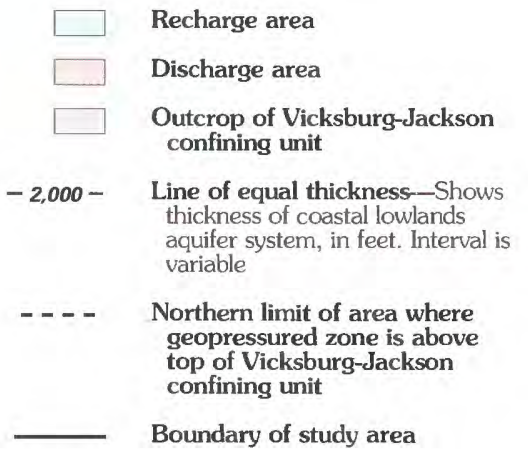

Base from U.S. Geological Survey Scale $1: 2,500,000$

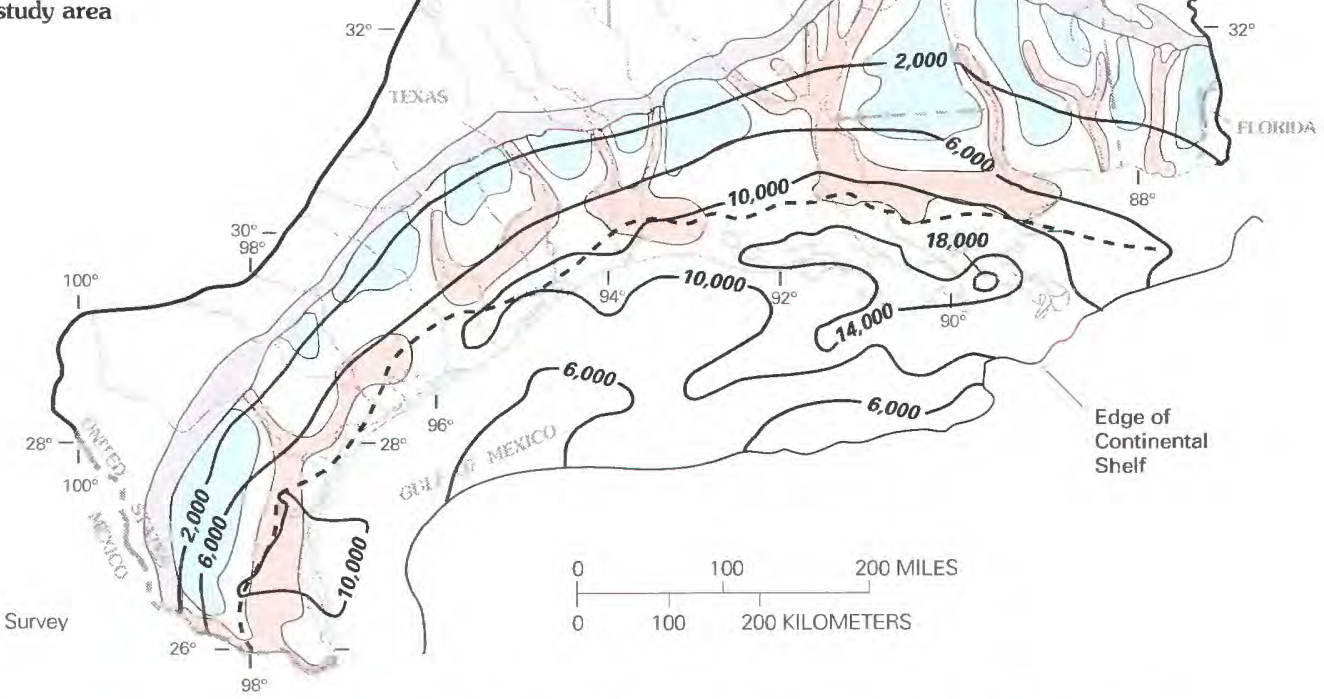

FiGURE 25.-Predevelopment regional recharge and discharge areas, and thickness: coastal lowlands aquifer system. 
and used as a basis for comparison with potentiometric surfaces of the 1980's.

The digital computer models used to simulate ground-water flow are of both regional and subregional scale. The regional-scale model consists of a rectangular grid divided into squares $10 \mathrm{mi}$ on each side, and the subregional-scale models have rectangular grids divided into squares $5 \mathrm{mi}$ on each side. Four of the 5 -mi squares therefore cover the same area as one square in the regional model. The regional-scale model simulated flow of variable-density ground water in 10 regional aquifers, whereas the subregional-scale models generally simulated only the freshwater part of one of the aquifer systems in fewer regional aquifers. These models simulated the regional flow but did not simulate local flow, water that enters and leaves the ground-water system within the area of a single model grid. A detailed discussion of model construction and underlying assumptions are included in the references cited in the previous paragraph.

\section{PREDEVELOPMENT}

Predevelopment ground-water flow was controlled by several factors in the Gulf Coastal Plain. Chief among these factors are topography, permeability, and the geometry of the aquifers and confining units. The predevelopment ground-water flow, based upon results from simulation, will be discussed first in a general way, highlighting instances where the major controlling factors are best illustrated from an aquifer-system perspective.

\section{RECHARGE AND DISCHARGE}

Simulated regional predevelopment ground-water flow in the coastal lowlands aquifer system generally was from areas of high water-level altitudes between the major rivers and adjacent to the outcrop band of the Vicksburg-Jackson confining unit, to the major rivers and to regional discharge areas parallel to the shoreline and centered about midway between the recharge areas and the shoreline (fig. 25). Major predevelopment regional discharge of freshwater to the Gulf of Mexico was probably only along the coast of Mississippi, Alabama, and Florida, where areas of high water-level altitudes were within a relatively short distance of the shoreline. The extensive flat topography with little relief throughout many of the coastal counties of Louisiana and Texas afforded little opportunity for development of other than local ground-water flow systems. The freshwater from the distant regional recharge areas was largely discharged landward from these coastal counties. Consequently, the uppermost sands throughout most of the coastal counties of Louisiana and Texas contain slightly saline water.

Simulated predevelopment ground-water flow in the Texas coastal uplands aquifer system generally was

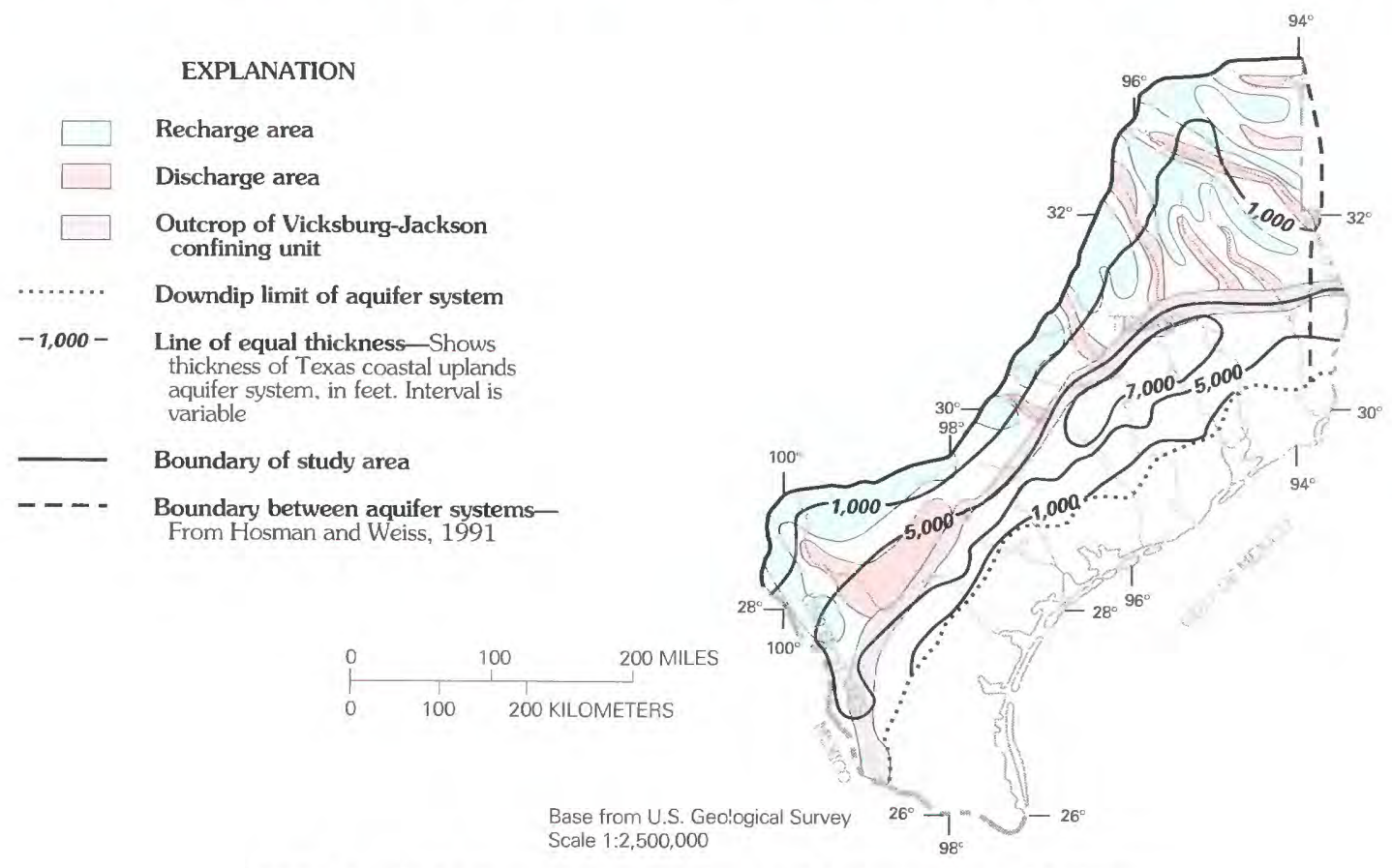

FIGURE 26.-Predevelopment regional recharge and discharge areas, and thickness: Texas coastal uplands aquifer system. 


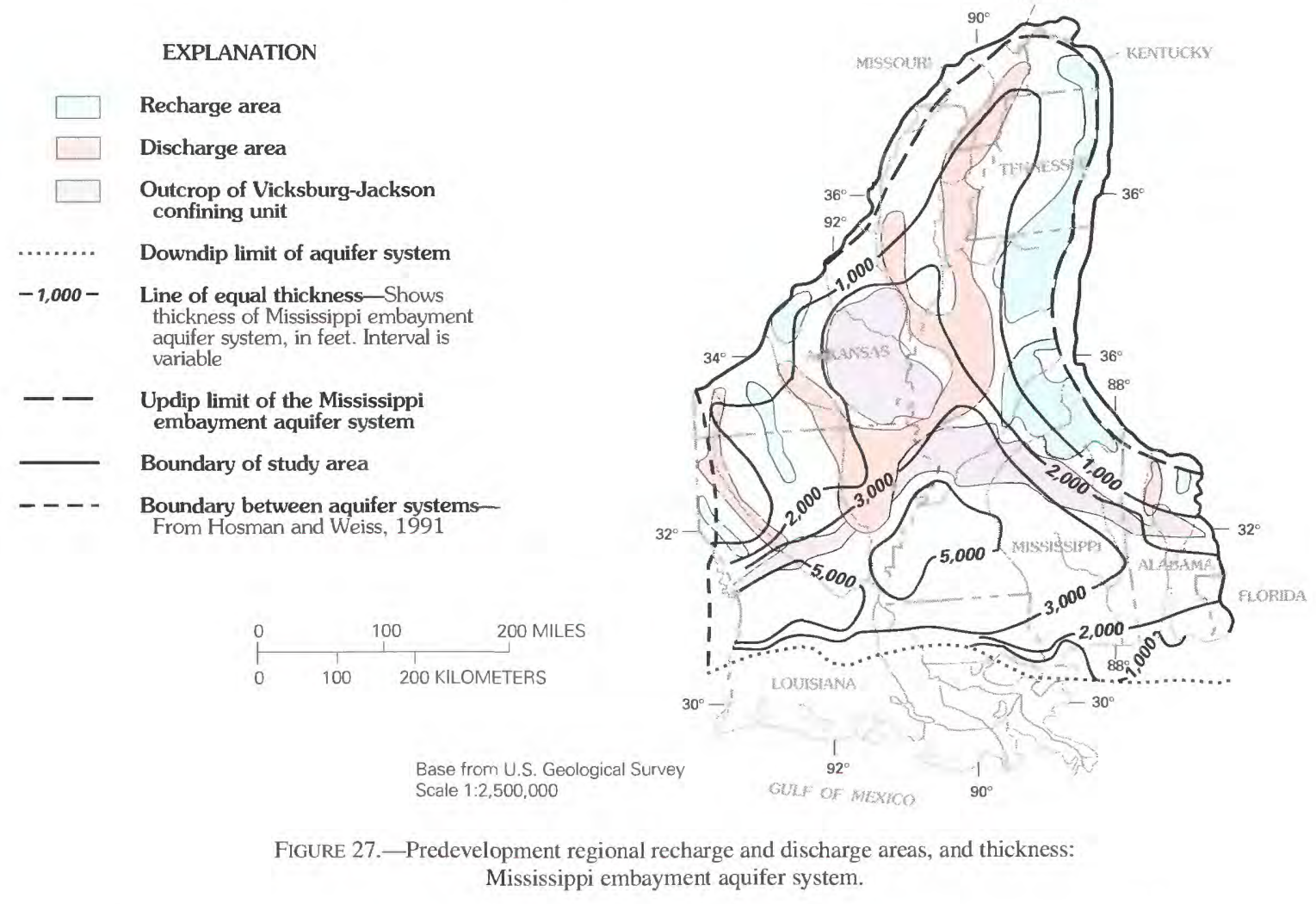

from areas of high water-level altitudes between the major rivers to narrow discharge areas in the vicinity of the rivers (fig. 26). Flow paths in this system typically were tens of miles in length. The minimal permeability of the Vicksburg-Jackson confining unit, which restricts the vertical movement of water from underlying aquifers, and the limited downdip extent of aquifers beneath the Vicksburg-Jackson confining unit limit the development of flow in aquifers underlying the confining unit.

Generally, regional predevelopment flow in the Mississippi embayment aquifer system was from areas of high water-level altitudes along the eastern side of the study area to the Mississippi Alluvial Plain in Missouri, Arkansas, northwestern Mississippi, and northeastern Louisiana (fig. 27). Some flow paths may have been as long as 200 to $300 \mathrm{mi}$. For example, water moved from aquifer outcrop areas in east-central Mississippi southward beneath the Vicksburg-Jackson confining unit and then northwestward toward a large regional discharge area in northeastern Louisiana. The minimal permeability of the Vicksburg-Jackson confining unit, in combination with low land-surface altitudes in northeastern Louisiana (on the western flank of a northward extension of the confining unit), accounts for these long flow paths.

\section{FLOW PATTERNS}

Predevelopment horizontal flow patterns were very complex and, as noted above, extended for tens of miles to hundreds of miles from recharge areas to discharge areas. Predevelopment horizontal flow ranged widely, as indicated by the results of ground-water flow simulation (figs. 28-31). Vertical flow generally was downward in aquifer outcrop areas and nearby areas that have high land-surface altitudes. Ground-water flow simulation indicates that most of the area underlain by an aquifer or permeable zone had upward vertical flow. Very large quantities of water flowed vertically from one permeable zone or aquifer to other permeable zones or aquifers. Following is a detailed look at the predevelopment flow patterns in permeable zone B of the coastal lowlands aquifer system and the middle Claiborne aquifer of the combined Texas coastal uplands and Mississippi embayment aquifer systems.

\section{PERMEABLE ZONE B}

The largest predevelopment horizontal flows in permeable zone B (lower Pleistocene-upper Pliocene deposits) were in southern Texas, southeastern Texas, southwestern Mississippi, and west-central Louisiana (fig. 29). Flow direction in southern Texas was from the outcrop area eastward toward the coast. East of the out- 


\section{EXPLANATION}

Generalized land-surface altitude of outcrop, in feet

\begin{tabular}{l|l|l}
\hline Less than 25 & 200 to 300 \\
& 300 to 400 \\
\hline$\square$ & 50 & \\
50 & to 100 & 400 to 500
\end{tabular}

\section{Area where simulated predevelopment vertical flow relative to base} of permeable zone was downward

Horizontal flow, in million gallons per day-Size of arrowhead indicates range of flow. Length of shaft indicates flow within stated range

Less than $0.1 \quad 0.1$ to $1.0 \quad 1.0$ to $10 \quad$ More than 10

$--100-\quad$ Structure contour-Shows altitude of top of aquifer. Contour interval, in feet, is variable. Vertical datum is sea level

Depth-averaged dissolved-solids concentration greater than 35,000 milligrams per liter downdip from line

Downdip limit of permeable zone

Location of salt domes that penetrate base of permeable zone

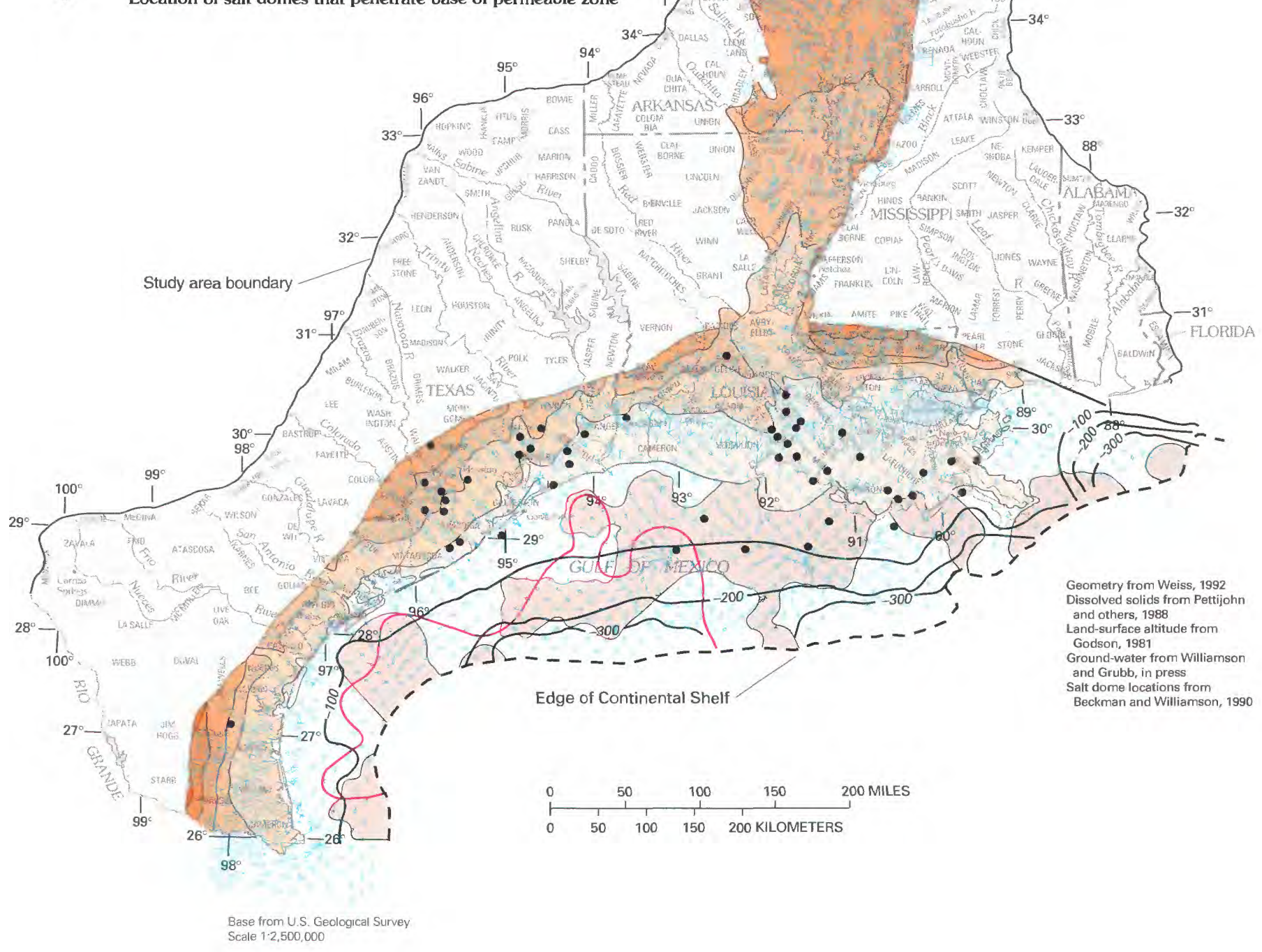

FIGURE 28.-Direction and relative magnitude of simulated predevelopment horizontal flow, area where vertical flow relative to base of permeable zone was downward, altitude and configuration of top, depth-averaged dissolved-solids concentration, and location of salt domes that penetrate base of permeable zone A, coastal lowlands aquifer system, and the Mississippi River Valley alluvial aquifer. 


\section{EXPLANATION}

Generalized land-surface altitude of outcrop, in feet

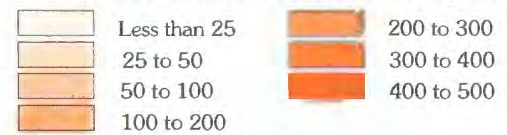

Area where simulated predevelopment vertical flow relative to base of permeable zone was downward

Horizontal flow, in million gallons per day - Size of arrowhead indicates range of flow. Length of shaft indicates flow within stated range

$$
\text { Less than } 0.1 \quad 0.1 \text { to } 1.0 \quad 1.0 \text { to } 10 \quad \text { More than } 10
$$

- -500 - Structure contour-Shows altitude of top of aquifer. Contour interval, in feet, is variable. Vertical datum is sea level

Depth-averaged dissolved-solids concentration greater than 35,000 milligrams per liter downdip from line

- - - Downdip limit of permeable zone

- Location of salt domes that penetrate base of permeable zone

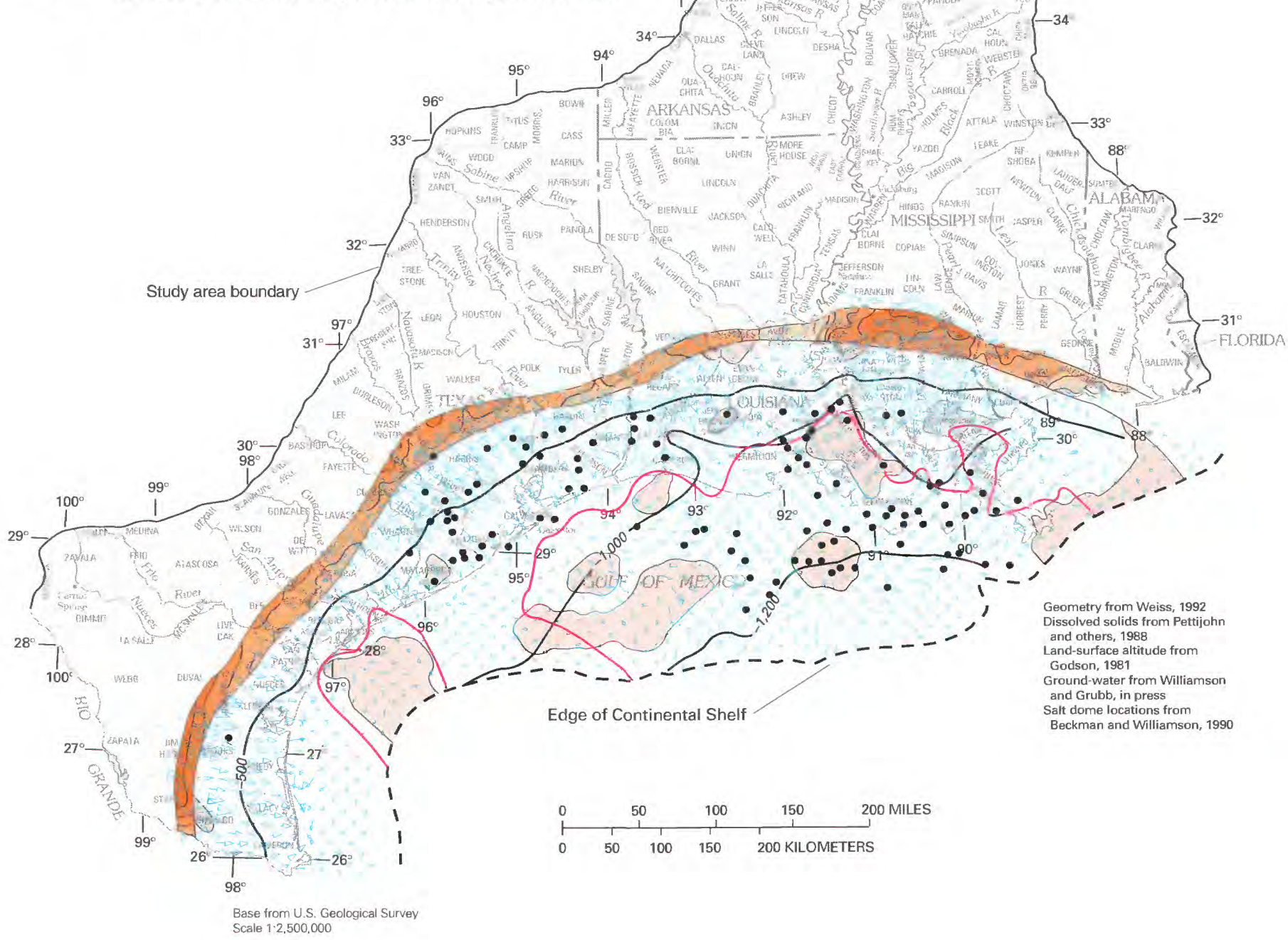

FIGURE 29.-Direction and relative magnitude of simulated predevelopment horizontal flow, area where vertical flow relative to base of permeable zone was downward, altitude and configuration of top, depth-averaged dissolved-solids concentration, and location of salt domes that penetrate base of permeable zone B, coastal lowlands aquifer system. 


\section{EXPLANATION}

Generalized land-surface altitude of outcrop, in feet

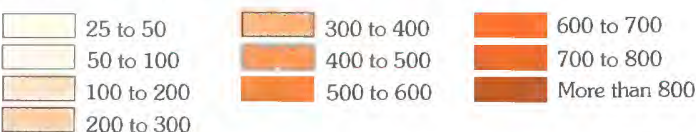

Area where simulated predevelopment vertical flow relative to base of permeable zone was downward

Horizontal flow, in million gallons per day-Size of arrowhead indicates range of flow. Length of shaft indicates flow within stated range

$$
\text { Less than } 0.1 \quad 0.1 \text { to } 1.0 \quad 1.0 \text { to } 10 \quad \text { More than } 10
$$

- 1,000- Structure contour-Shows altitude of top of aquifer. Contour interval, in feet, is variable. Vertical datum is sea level

Depth-averaged dissolved-solids concentration greater than 35,000 milligrams per liter downdip from line

- - - Downdip limit of permeable zone

Location of salt domes that penetrate base of permeable zone

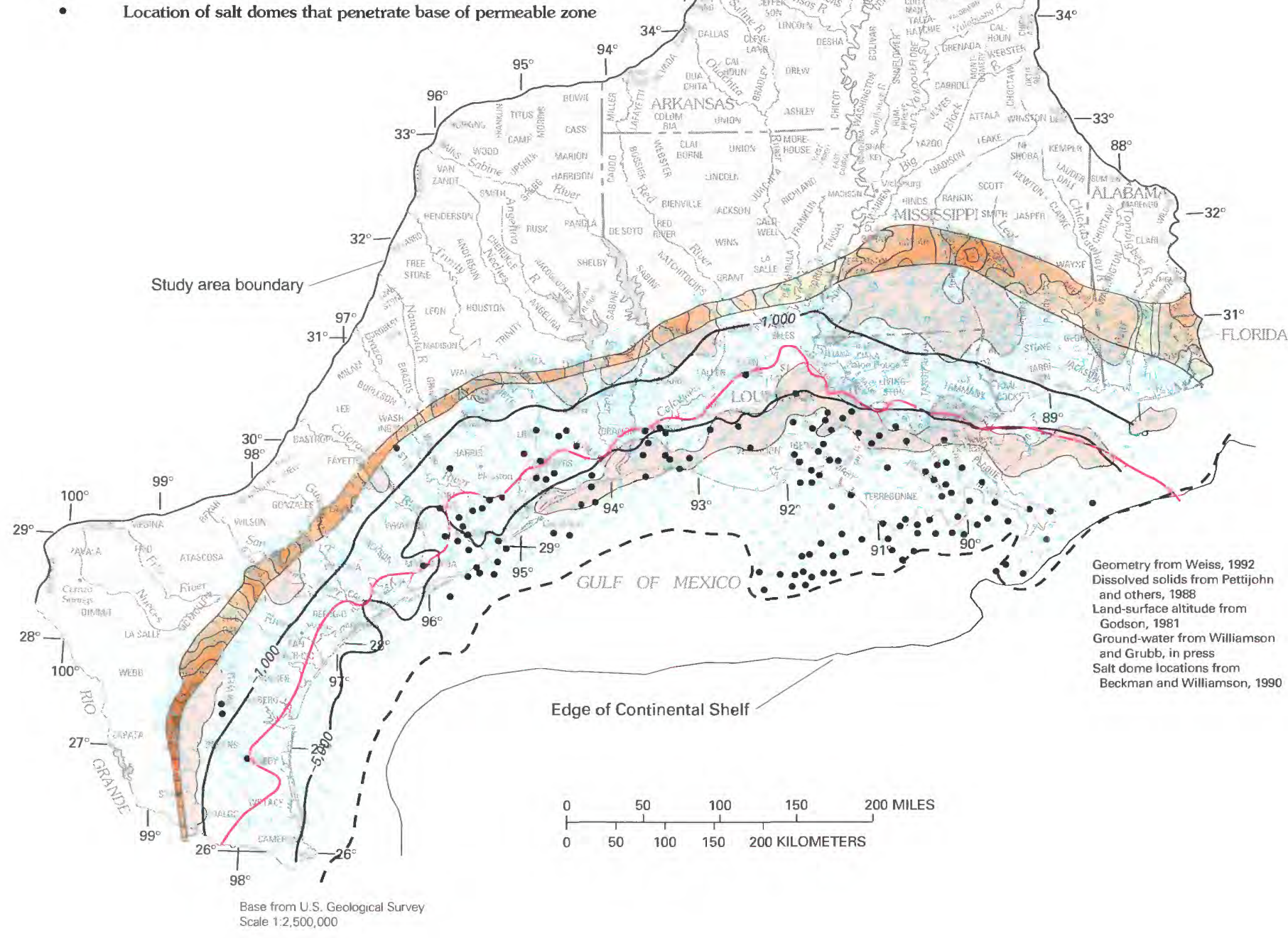

FIGURE 30.-Direction and relative magnitude of simulated predevelopment horizontal flow, area where vertical flow relative to base of permeable zone was downward, altitude and configuration of top, depth-averaged dissolved-solids concentration, and location of salt domes that penetrate base of permeable zone D, coastal lowlands aquifer system. 


\section{EXPLANATION}

Generalized land-surface altitude of outcrop, in feet

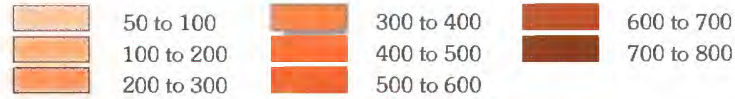

Area where simulated predevelopment vertical flow relative to base of permeable zone was downward

Horizontal flow, in million gallons per day-Size of arrowhead indicates range of flow. Length of shaft indicates flow within stated range

$$
\text { Less than } 0.1 \quad 0.1 \text { to } 1.0 \quad 1.0 \text { to } 10 \quad \text { More than } 10
$$

- -100 - Structure contour-Shows altitude of top of aquifer. Contour interval, in feet, is variable. Vertical datum is sea level

Depth-averaged dissolved-solids concentration greater than 35,000 milligrams per liter downdip from line

Downdip limit of permeable zone

Boundary of Mississippi embayment and Texas Coastal Uplands aquifer system

- Location of salt domes that penetrate base of permeable zone

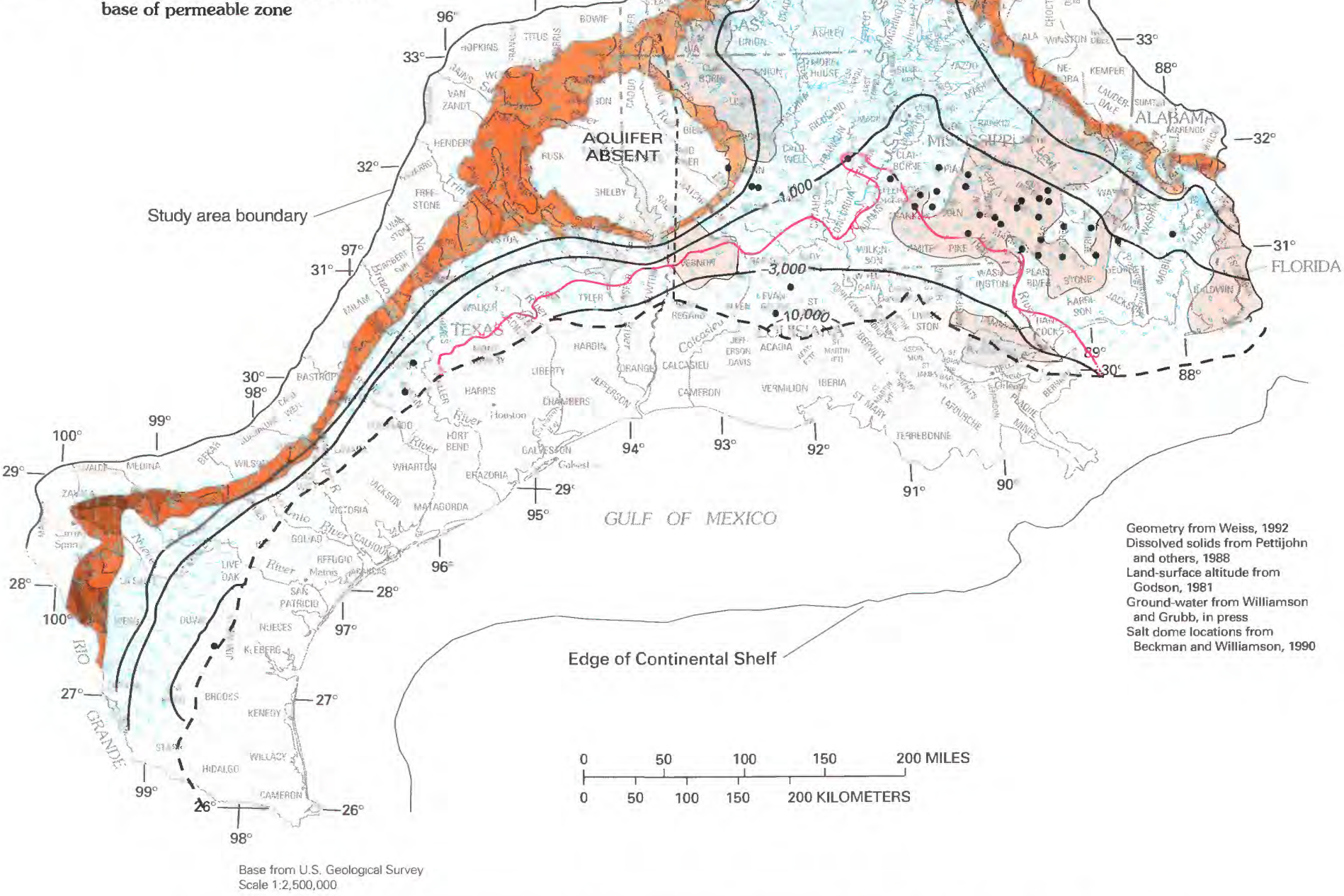

FIGURE 31.-Direction and relative magnitude of simulated predevelopment horizontal flow, area where vertical flow relative to base of permeable zone was downward, altitude and configuration of top, depth-averaged dissolved-solids concentration, and location of salt domes that penetrate base of middle Claiborne aquifer, Texas coastal uplands and Mississippi embayment aquifer systems. 
crop areas, horizontal flow decreased substantially throughout most of the coastal counties where land-surface altitudes are generally less than $50 \mathrm{ft}$ above sea level. The small flow vectors at the shoreline (fig. 29) indicate that most of the freshwater had been discharged from the aquifer. Water moved upward all along the flow paths from a short distance downdip from the outcrop area to the shoreline. At the shoreline, eastward-flowing freshwater met westward-moving saline water. The horizontal flow of saline water offshore was less than the flow of freshwater onshore, as indicated by the much smaller flow vectors offshore on the Continental Shelf than the flow vectors onshore.

Horizontal flow outward from the outcrop area of permeable zone B in southeastern Texas was southeastward toward the coast. Horizontal flow decreased substantially where land-surface altitudes are generally less than $50 \mathrm{ft}$ above sea level, about 30 to $40 \mathrm{mi}$ inland from the shoreline. Vertical flow was upward to the overlying permeable zone along most of the flow paths from an area just gulfward from the outcrop area to the shoreline. Small horizontal flow radiated outward from two bodies of dense water offshore from Texas. The dense water is approximately outlined by the $35,000-\mathrm{mg} / \mathrm{L}$ dissolved-solids concentration line shown in figure 29.

The large horizontal flows in southwestern Mississippi radiated outward from the outcrop to the west, southwest, and south. Flow decreased substantially at the Mississippi River to the west and southwest where the river flows along the eastern side of the Mississippi Alluvial Plain. All flow to the west discharged upward to the overlying permeable zone within about $10 \mathrm{mi}$ of the Mississippi River, as indicated by the meeting of eastward- and westward-pointing flow vectors (fig. 29). Flow decreased substantially to the south about 70 to $100 \mathrm{mi}$ from the shoreline where land-surface altitudes are typically less than $50 \mathrm{ft}$ above sea level. Northward flow from the Continental Shelf met the southward flow as much as $50 \mathrm{mi}$ inland from the coast. The northward flow was associated with a large body of dense water in this permeable zone that extended throughout most of offshore Louisiana and most coastal parishes of southeastern Louisiana. This body of dense water is approximately outlined by the line marking a dissolved-solids concentration of 35,000 mg/L in figure 29.

Large horizontal flow in west-central Louisiana was generally to the south and extended throughout an area of several hundred square miles from an area of high land-surface altitude near the Louisiana-Texas boundary. This area of large horizontal flow was much smaller than the other three discussed above, and flow decreased substantially within $40 \mathrm{mi}$ of the outcrop area. Most of the flow had discharged upward to the overlying permeable zone inland from the coast where flow vectors are about parallel to shoreline (fig. 29).

\section{MIDDLE CLAIBORNE AQUIFER}

Large predevelopment horizontal flows in the middle Claiborne aquifer were in southern and northeastern Texas, southern Arkansas and adjacent parts of Louisiana, central Mississippi, and western Tennessee and adjacent parts of Mississippi (fig. 31). Flow in southern Texas was to the east, south, and southwest from the outcrop area of the aquifer and decreased substantially near the downdip extent of the aquifer. The flow to the south and southwest discharged to the Rio Grande, and the flow to the east discharged in the vicinity of the Guadalupe River. Upward flow to the overlying upper Claiborne aquifer occurred all along the flow paths; thus, flows were reduced substantially to the east and southwest near the downdip limit of the aquifer.

The horizontal flow vectors in northeastern Texas (fig. 31) appear to be disordered compared to those in southern Texas. Most discharge was to the streams that flow across the outcrop area. Long regional flow paths were present only where substantially smaller flows were parallel to the outcrop area in the confined part of the aquifer. Semicircular flow was associated with a large body of dense water that extended from Texas across adjacent parts of Louisiana into southern Mississippi. The semicircular feature is centered in central Louisiana. The body of dense water is approximately delineated by the dissolved-solids concentration line of $35,000 \mathrm{mg} / \mathrm{L}$ in figure 31 .

Horizontal flow lines from southern Arkansas and adjacent parts of Louisiana converged along the Ouachita River and at a large regional discharge area in northeastern Louisiana. Some of the northernmost flow lines radiating from the outcrop area of southern Arkansas extended southeastward past the Mississippi River and converged along a discharge line northwest of the area of large horizontal flow in central Mississippi. The discharge line extended into the southernmost part of the subcrop of the middle Claiborne aquifer beneath the Mississippi River Valley alluvial aquifer. The relatively low-lying Mississippi Alluvial Plain extends several miles to the east of the Mississippi River in the vicinity of the line of discharge. Some of the southernmost flow lines radiating outward from the outcrop area of central Mississippi crossed the Mississippi River and converged to the regional discharge area in northeastern Louisiana.

Flow lines radiating outward from the area of large horizontal flow in western Tennessee and adjacent Mississippi extended a relatively short distance to the west 

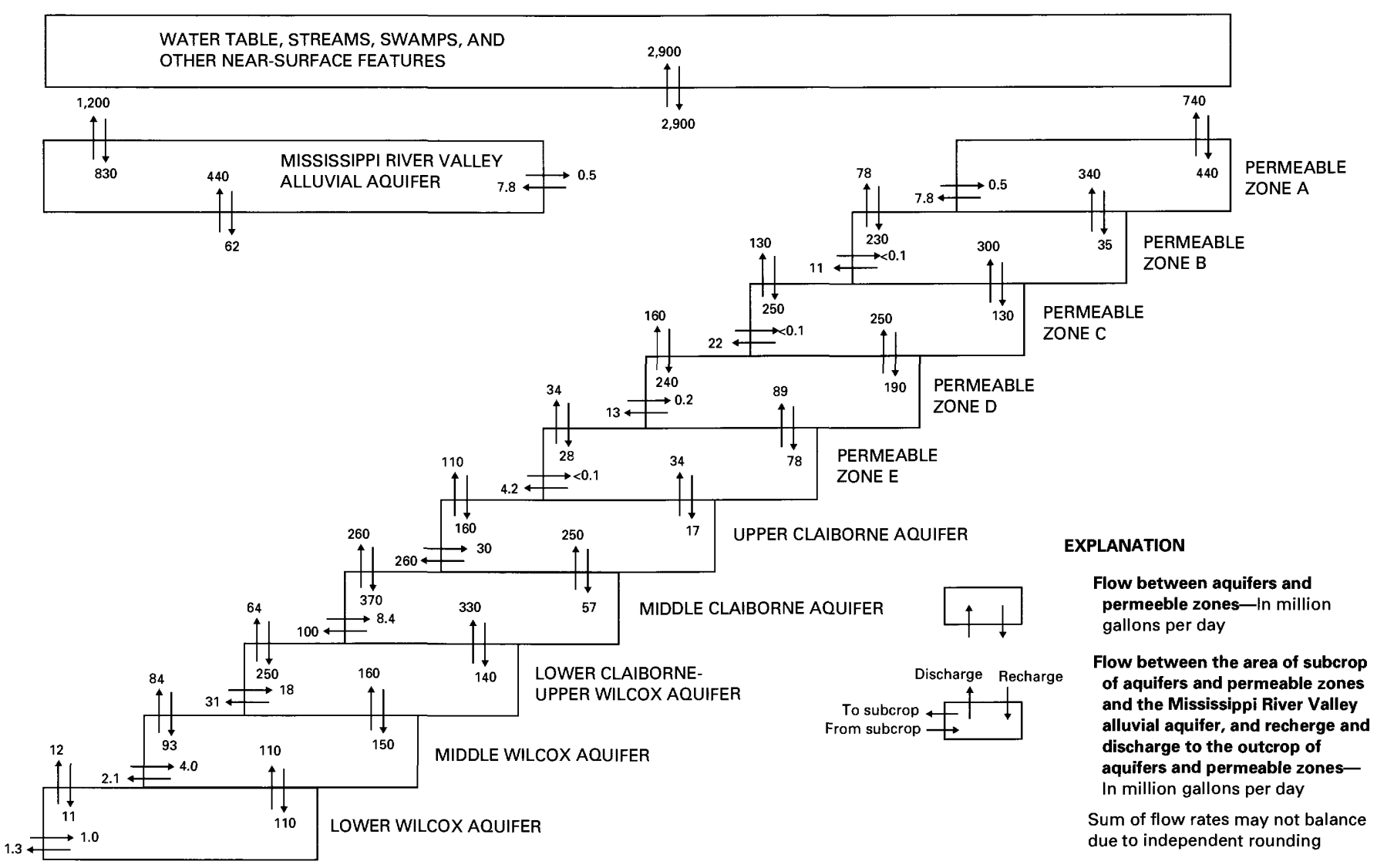

FIGURE 32.- Simulated predevelopment ground-water budget from the regional-scale model.

before flow was reduced substantially near the edge of the Mississippi Alluvial Plain. The flow from the northernmost part of the area was to the northwest toward Missouri. The flow lines extended past the Mississippi River into Arkansas before they turned to the west and then to the south, where they converged with flow lines from the west.

\section{GROUND-WATER BUDGET}

The regional ground-water budget for predevelopment (fig. 32) accounts for inflows to and outflows from each aquifer or permeable zone. Outflow from an aquifer or permeable zone is either (1) discharge to the water table or surface-water body within the outcrop area of the same aquifer or permeable zone, or (2) flow upward to overlying aquifers or permeable zones. Simulated predevelopment recharge was about $1,300 \mathrm{Mgal} / \mathrm{d}$ to the combined Mississippi River Valley alluvial aquifer and permeable zone $\mathrm{A}$ and about $1,600 \mathrm{Mgal} / \mathrm{d}$ to all other aquifers and permeable zones (fig. 32). The net recharge of about $700 \mathrm{Mgal} / \mathrm{d}$ to all aquifers and permeable zones except the Missis- sippi River Valley alluvial aquifer and permeable zone A was discharged to permeable zone A and the Mississippi River Valley alluvial aquifer in nearly equal volumes. Net recharge ranged from less than $1 \mathrm{Mgal} / \mathrm{d}$ to the lower Wilcox aquifer to about $190 \mathrm{Mgal} / \mathrm{d}$ to the lower Claiborne-upper Wilcox aquifer. Vertical flows ranged from less than $1 \mathrm{Mgal} / \mathrm{d}$ between the lower Wilcox aquifer and the middle Wilcox aquifer to about $300 \mathrm{Mgal} / \mathrm{d}$ between permeable zone B and permeable zone A (fig. 32).

Net simulated recharge among the permeable zones of the coastal lowlands aquifer system was least to permeable zone $\mathrm{E}$ and greatest to permeable zone B (Martin and Whiteman, in press; Ryder and Ardis, in press). The largest vertical flow between permeable zones was upward from permeable zone B to permeable zone A. Permeable zone A was a net predevelopment discharge area because it underlies a large area where the landsurface altitude commonly is less than $50 \mathrm{ft}$ above sea level, and the vertical gradients in the underlying permeable zones are predominantly upward.

Net simulated recharge among the aquifers of the Texas coastal uplands aquifer system was least to the 
middle Wilcox aquifer and greatest to the lower Claiborne-upper Wilcox aquifer (Ryder and Ardis, in press). The largest vertical flow between aquifers was upward from the middle Claiborne aquifer to the upper Claiborne aquifer. The outcrop area of the upper Claiborne aquifer was a net discharge area because the predominant vertical flow from all the underlying aquifers was upward, and the upper Claiborne aquifer is the uppermost aquifer in the aquifer system. Vertical flow from the upper Claiborne aquifer to the coastal lowlands aquifer system was restricted to a small quantity by the minimal permeability of the Vicksburg-Jackson confining unit.

Net simulated recharge among the aquifers of the Mississippi embayment aquifer system was least to the lower Wilcox aquifer and greatest to the lower Claiborne-upper Wilcox aquifer (Arthur and Taylor, in press). The largest vertical flow between aquifers was upward from the middle Claiborne aquifer to the upper Claiborne aquifer. Most of the net recharge was discharged to the Mississippi River Valley alluvial aquifer where the aquifers subcrop; about equal quantities were discharged from the upper Claiborne aquifer and all other aquifers combined. The large volume of vertical flow upward from the upper Claiborne aquifer was because of the predominant vertical upward gradient in all the aquifers underlying the area where the upper Claiborne aquifer subcrops the Mississippi River Valley alluvial aquifer. Vertical flow from the upper Claiborne aquifer to the coastal lowlands aquifer system was restricted to a small quantity by the minimal permeability of the Vicksburg-Jackson confining unit.

\section{EFFECTS OF WATER DENSITY}

The simulated flow directions in aquifers and permeable zones are substantially affected by water density that is greater than about $1.025 \mathrm{~g} / \mathrm{cm}^{3}$. The effects such as vertical flows that are downward, increased volume of horizontal flow, and semicircular horizontal flow patterns are illustrated by comparison of simulated results for permeable zones $\mathrm{A}, \mathrm{B}$, and $\mathrm{D}$. The effects of water density are more evident for permeable zones D, C, E, and B in the coastal lowlands aquifer system and for the middle Wilcox aquifer of the Mississippi embayment aquifer system.

Vertical flow relative to the base of permeable zone A was downward through an area of about $12,000 \mathrm{mi}^{2}$ offshore from Louisiana and about $8,000 \mathrm{mi}^{2}$ offshore from Texas (fig. 28). Throughout most of the area where the flow was downward, a column of seawater (density of $1.025 \mathrm{~g} / \mathrm{cm}^{3}$ ) overlies permeable zone $\mathrm{A}$ and increases in height (up to $300 \mathrm{ft}$ ) from the shoreline toward the edge of the Continental Shelf. Where the vertical flow in the offshore area was downward from permeable zone A, water density generally was greater than $1.000 \mathrm{~g} / \mathrm{cm}^{3}$ in permeable zone A and greater than $1.020 \mathrm{~g} / \mathrm{cm}^{3}$ in permeable zone $B$. The less dense water was discharged from permeable zone A to the Gulf of Mexico throughout most of the Continental Shelf where vertical flow was not downward relative to the base of permeable zone $\mathrm{A}$. The two points offshore where horizontal flow arrows meet in permeable zone A are the centers of bodies of dense water in permeable zone B (figs. 28 and 29).

Vertical flow relative to the base of permeable zone B (fig. 29) was downward through some of the same offshore area as for permeable zone A (fig. 28). However, the total area was less, and the volume of vertical flows generally were smaller for permeable zone $B$ than for permeable zone A. Water density in permeable zone B was greater than $1.04 \mathrm{~g} / \mathrm{cm}^{3}$ in those areas of offshore Louisiana where the downward vertical flows across the base of permeable zone B were largest. Horizontal flows along flow paths that originated 10 to $20 \mathrm{mi}$ offshore from Galveston Bay in permeable zone B and extended to the east and southeast became larger offshore from southwestern Louisiana where they turned to the south. A substantial volume of downward vertical flow across the base of permeable zone A was present (fig. 28) in the area where horizontal flows became larger in permeable zone B (fig. 29).

Vertical flow relative to the base of permeable zone D (fig. 30) was downward only onshore because the underlying permeable zone E did not extend offshore. A body of dense water (generally ranging in density from 1.04 to $1.06 \mathrm{~g} / \mathrm{cm}^{3}$ ) extended across southern Louisiana; however, downward flow relative to the base of permeable zone $\mathrm{D}$ was present throughout an area of about $4,500 \mathrm{mi}^{2}$. The semicircular horizontal flow patterns in this permeable zone (fig. 30) across southern Louisiana are coincident with the northern margin of the dense water body described above.

\section{FLOW DURING THE 1980's}

Several significant changes in ground-water flow due to ground-water withdrawals were evident by the 1980 's throughout much of the Gulf Coastal Plain. Many of the changes had been in progress for many years but reached maximum magnitude by the 1980's. Some changes have been documented, such as lowering of water levels, land subsidence, loss of saturated thickness, and saltwater encroachment. Other changes, such as changes in direction of vertical ground-water flow, increases in regional recharge, decreases in regional discharge, and large-scale changes in direction of horizon- 
tal flow, are not as readily observable by direct measurement, but they are nonetheless real and significant to the long-term use and management of the ground-water resource. These less obvious changes in ground-water flow are best demonstrated by comparing and contrasting predevelopment conditions to conditions during the 1980's. Results from ground-water flow models that use regionally consistent data make possible the comparisons and contrasts that highlight the less obvious changes in the ground-water flow system.

\section{RECHARGE AND DISCHARGE}

Most of the onshore predevelopment regional discharge areas had become net regional recharge areas by 1985. Three notable exceptions are: the valley of the Tombigbee River in Alabama, the valley of the Trinity River where it crosses the Texas coastal uplands aquifer system, and the valley of the Nueces River, which is connected to a discharge area along the coast of southern Texas (Williamson and others, 1990).

Many regional discharge areas along the valleys of major streams in the coastal lowlands aquifer system had become net recharge areas by the 1980's. The regional recharge areas across southeastern Texas (fig. 25) merged to form one large area of net recharge extending from the Guadalupe River eastward to the Trinity River. Discharge areas along the Texas streams were separated from the coastal discharge area where it still existed in 1982 except for the area along the Rio Grande (Ryder and Ardis, in press). By 1985, the coastal area of southwestern Louisiana that was a discharge area under predevelopment conditions (fig. 25) was greatly reduced, as the area of recharge expanded to encompass most of southwestern Louisiana except for short segments of the major stream valleys gulfward from the Vicksburg-Jackson confining unit (Martin and Whiteman, in press). Most of the Mississippi Alluvial Plain from Vicksburg, Mississippi, to the Gulf of Mexico had changed from a net regional discharge area under predevelopment conditions to a net regional recharge area by 1985 (Martin and Whiteman, in press). Discharge to the Pearl, Pascagoula, and Tombigbee Rivers continued during 1985.

Discharge to the valleys of the major rivers in the Texas coastal uplands aquifer system was the least changed by ground-water withdrawal. Although the size of the areas adjacent to the streams receiving regional predevelopment discharge had, in most instances, decreased by the 1980 's, they were still net discharge areas. An example is a large predevelopment discharge area in southern Texas (fig. 26) that decreased in size by several tens of square miles due to with- drawal of ground water for irrigation (Ryder and Ardis, in press).

Most of the Mississippi Alluvial Plain was a net regional recharge area to the Mississippi embayment aquifer system by the 1980 's. However, discharge continued in an area of Kentucky, Missouri, and Tennessee adjacent to the Mississippi River in the northern part of the embayment (fig. 27). Also, simulation shows discharge along a short segment of the Ouachita River in southern Arkansas and adjacent Louisiana, and along the Yazoo River and tributaries of the Pascagoula River in Mississippi (Arthur and Taylor, in press).

\section{FLOW PATTERNS}

Changes in regional flow patterns from predevelopment have resulted from ground-water withdrawals. The most notable are changes in direction of horizontal flow paths that extend for hundreds of miles from pumping centers, and a reversal in vertical flow direction from vertically upward to vertically downward throughout thousands of square miles. These changes are shown by comparing figures $28-31$ with figures 3336 . The flow patterns in permeable zone $B$ and the middle Claiborne aquifer will be used as examples to illustrate some of the changes.

\section{PERMEABLE ZONE B}

The largest changes in flow from predevelopment to the 1980's in permeable zone B (lower Pleistoceneupper Pliocene deposits) were in southeastern Texas and southeastern Louisiana and the adjacent offshore area (compare figs. 29 and 34). Ground-water withdrawals in southern Texas and west-central Louisiana had caused little change in either direction or quantity of flow by the 1980's.

By 1985 horizontal flow in southeastern Texas was toward an area with large pumpage centered near Houston in Harris County. The predevelopment flow direction from the outcrop area toward the gulf $w$ as still maintained except that near the center of pumpage many of the flow lines became parallel to the shoreline (fig. 34). Also, the convergence of predevelopment flow lines near the shoreline was changed by ground-water development. Currently (1985), flow from several tens of miles offshore moves toward the center of pumpage located several tens of miles inland from the gulf near Houston. The quantity of flow just inland from the gulf is substantially larger than during predevelopment and moves in the opposite direction (that is from the gulf tow ard the center of pumpage). The direction of vertical flow relative to the base of permeable zone $B$ has been reversed throughout an area of several hundred square miles that is coincident with much of the area of 


\section{EXPLANATION}

Horizontal flow, in million gallons per day - Size of arrowhead indicates range of flow. Length of shaft indicates flow within stated range

Less than $0.1 \quad 0.1$ to $1.0 \quad 1.0$ to $10 \quad$ More than 10

Area where simulated vertical flow relative to base of permeable zone $\mathrm{A}$ and Mississippi River Valley alluvial aquifer was downward during 1987, a reversal in direction from predevelopment conditions

- 200 - Line of equal horizontal hydraulic conductivity - Interval, in feet per day, is variable. Hachures indicate closed area of lesser hydraulic conductivity

\section{- Updip boundary of permeable zone}

Aquifer-system boundary-Mississippi River Valley alluvial aquifer north of line and permeable zone A south of line

Downdip limit of permeable zone is edge of Continental Shelf

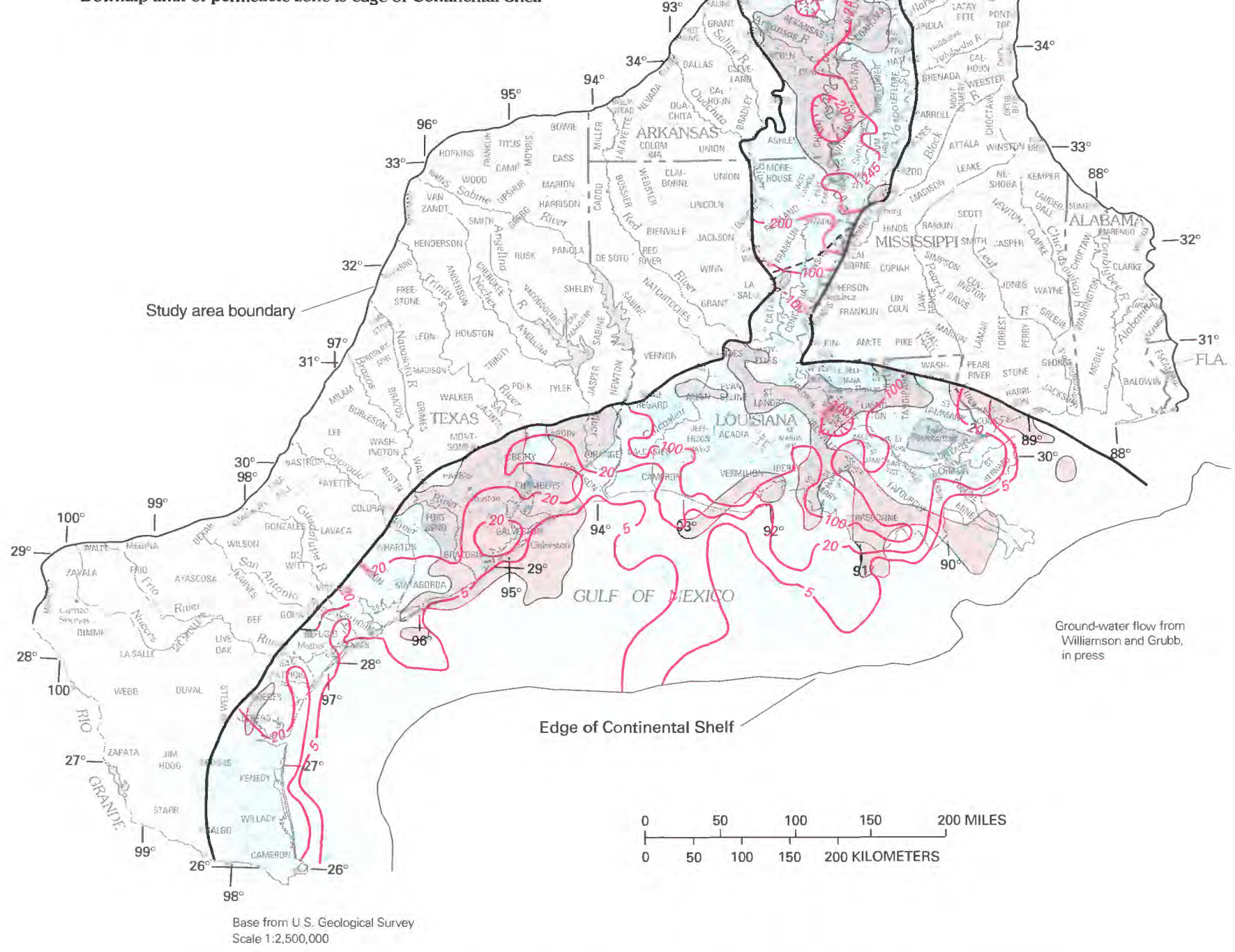

FIGURE 33.--Regionalized horizontal hydraulic conductivity, areas where simulated vertical flow relative to base of unit reversed direction from upward to downward (predevelopment to 1987), and 1987 simulated direction and relative magnitude of horizontal flow in permeable zone A, coastal lowlands aquifer system, and the Mississippi River Valley alluvial aquifer. 


\section{EXPLANATION}

Horizontal flow, in million gallons per day-Size of arrowhead indicates range of flow. Length of shaft indicates flow within stated range

$$
\text { Less than } 0.1 \quad 0.1 \text { to } 1.0 \quad 1.0 \text { to } 10 \quad \text { More than } 10
$$

Area where simulated vertical flow relative to base of permeable zone $B$ was downward during 1987, a reversal in direction from predevelopment conditions

$-10-\quad$ Line of equal horizontal hydraulic conductivity - Interval, in feet per day. is variable. Hachures indicate closed area of lesser hydraulic conductivity

- - Updip boundary of permeable zone-Dashed at subcrop or where concealed

Downdip limit of permeable zone is edge of Continental Shelf

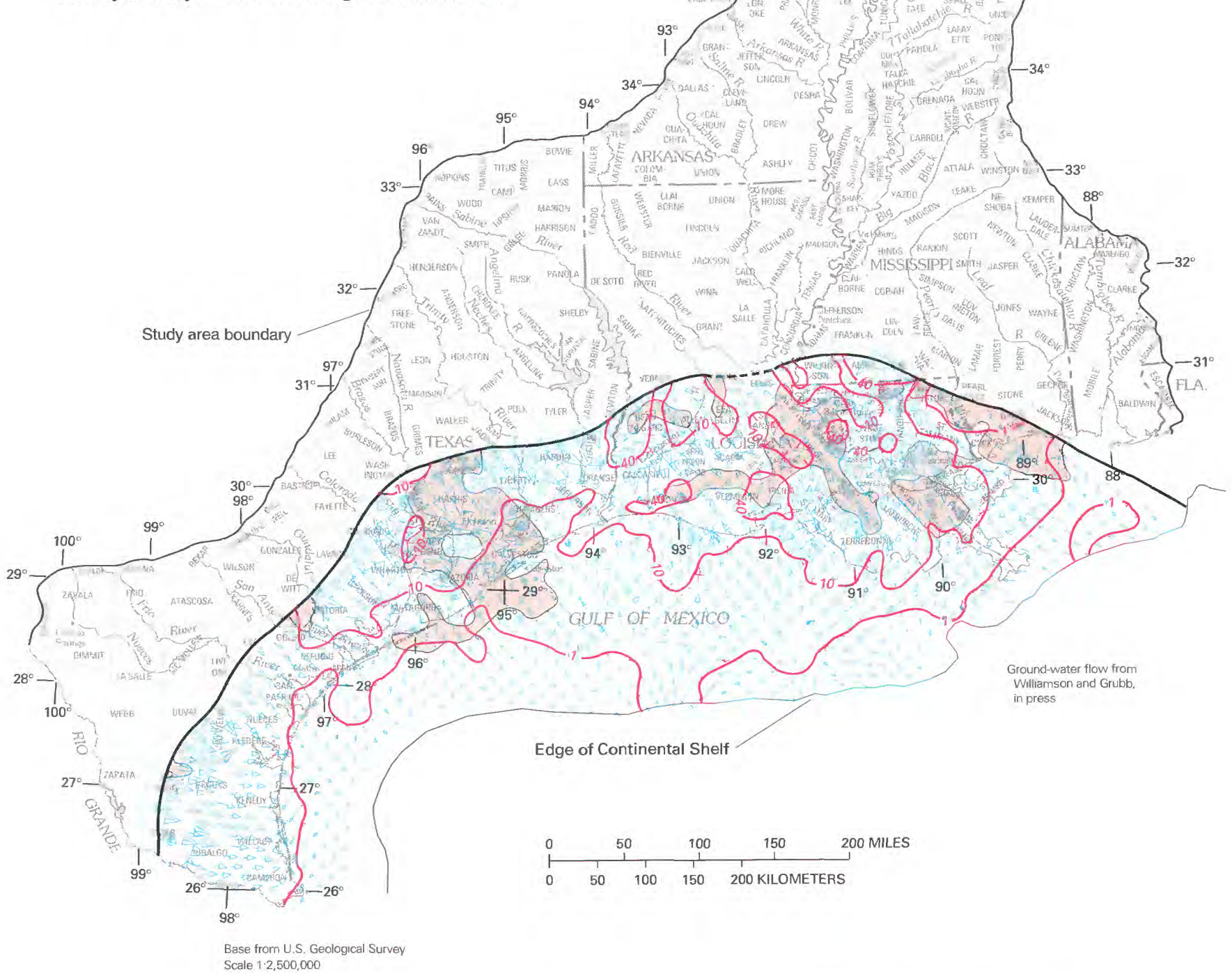

FIGURE 34.-Regionalized horizontal hydraulic conductivity, areas where simulated vertical flow relative to base of unit reversed direction from upward to downward (predevelopment to 1987), and 1987 simulated direction and relative magnitude of horizontal flow in permeable zone $\mathrm{B}$, coastal lowlands aquifer system. 


\section{EXPLANATION}

Horizontal flow, in million gallons per day-Size of arrowhead indicates range of flow. Length of shaft indicates flow within stated range

Less than $0.1 \quad 0.1$ to $1.0 \quad 1.0$ to $10 \quad$ More than 10

Area where simulated vertical flow relative to base of permeable zone $\mathrm{D}$ was downward during 1987, a reversal in direction from predevelopment conditions

$-1-$

Line of equal horizontal hydraulic conductivity - Interval, in feet per day, is variable. Hachures indicate closed area of lesser hydraulic conductivity

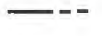

Updip boundary of permeable zone-Dashed at subcrop or where concealed

Downdip limit of permeable zone

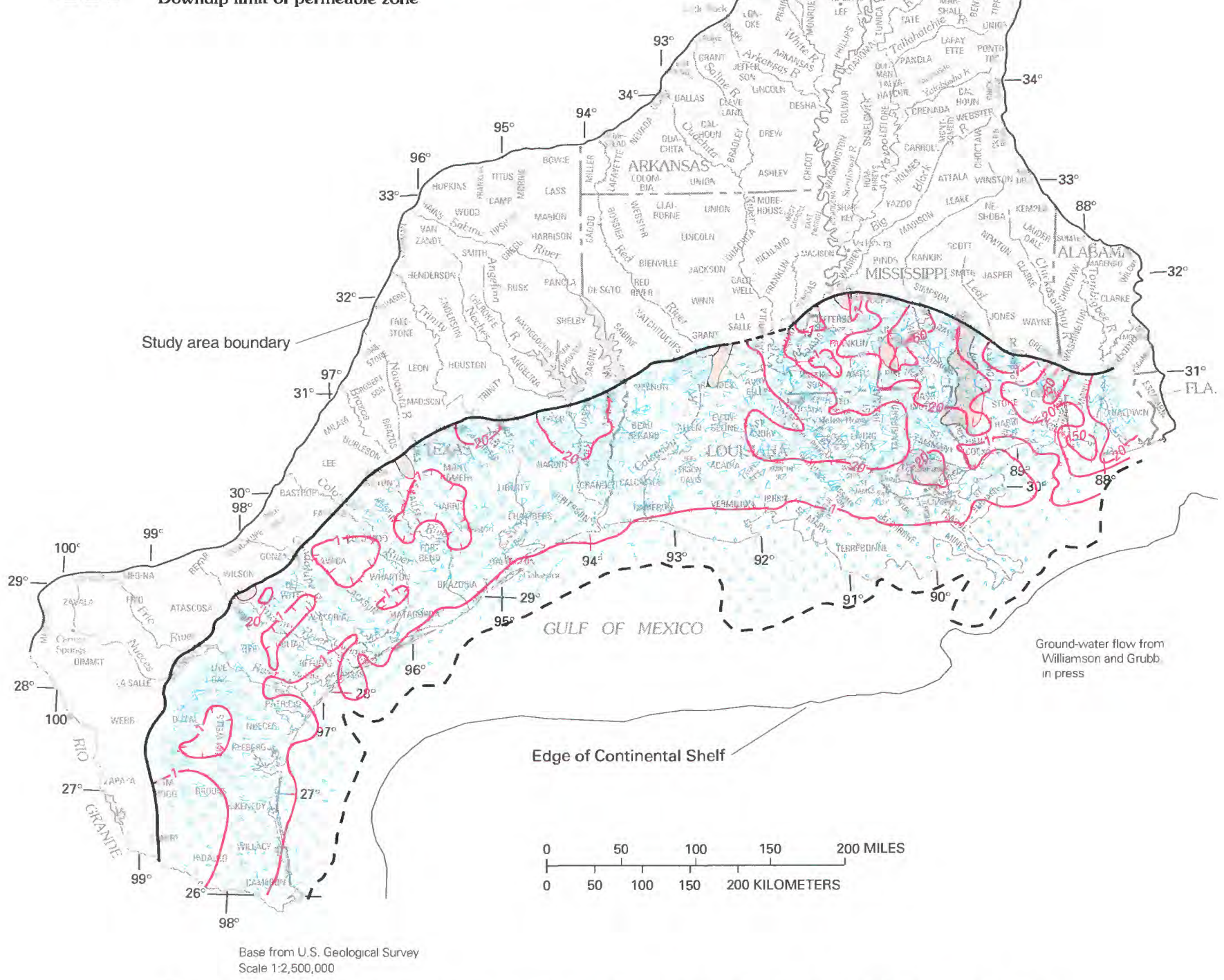

FIGURE 35.-Regionalized horizontal hydraulic conductivity, areas where simulated vertical flow relative to base of unit reversed direction from upward to downward (predevelopment to 1987), and 1987 simulated direction and relative magnitude of horizontal flow in permeable zone D, coastal lowlands aquifer system. 


\section{EXPLANATION}

Horizontal flow, in million gallons per day - Size of arrowhead indicates range of flow. Length of shaft indicates flow within stated range

$$
\text { Less than } 0.1 \rightarrow 0.1 \text { to } 1.0 \rightarrow 1.0 \text { to } 10 \rightarrow \text { More than } 10
$$

Area where simulated vertical flow relative to base of middle Claiborne aquifer was downward during 1987. A reversal in direction from predevelopment conditions

- 5 - Line of equal horizontal hydraulic conductivity - Interval, in feet per day, is variable.

- - Updip boundary of aquifer-Dashed at subcrop or where concealed

- - Downdip limit of aquifer

Boundary between Mississippi embayment and Texas coastal uplands aquifer systems

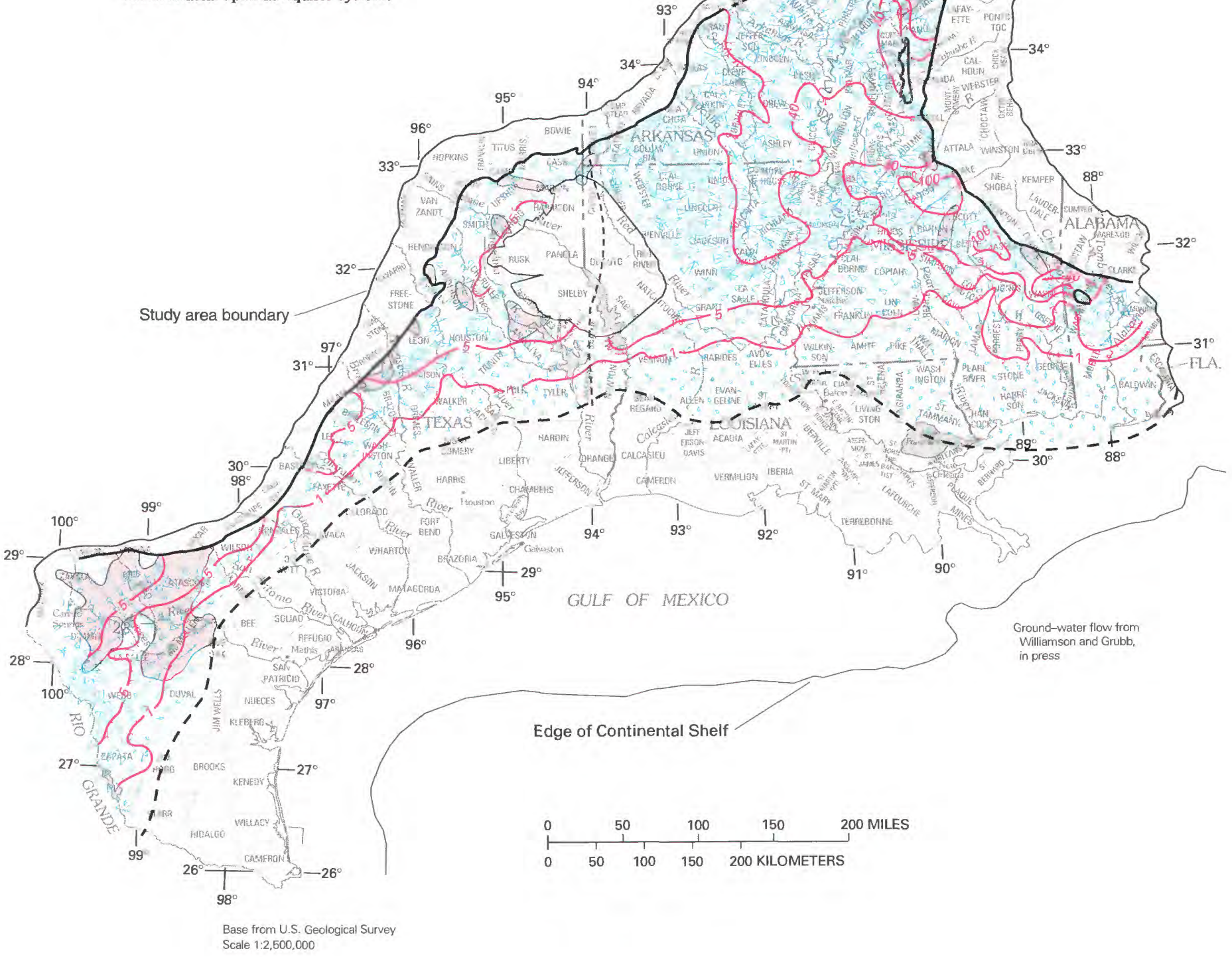

FIGURE 36.- Regionalized horizontal hydraulic conductivity, areas where simulated vertical flow relative to base of unit reversed direction from upward to downward (predevelopment to 1987), and 1987 simulated direction and relative magnitude of horizontal flow in middle Claiborne aquifer, Texas coastal uplands and Mississippi embayment aquifer systems. 
ground-water withdrawal in southeastern Texas (compare figs. 29 and 34). Under predevelopment conditions, flow was upward from underlying units through permeable zone $\mathrm{B}$ to permeable zone $\mathrm{A}$ and eventually discharged to the water table, or to streams, lakes, swamps, and other surface-water features. As a result of large-scale ground-water pumpage water was flowing downward from permeable zone B by the 1980's in order to supply the pumpage from permeable zone $C$.

Flow toward a center of pumpage at Baton Rouge, La., resulted in a change in direction of both horizontal and vertical ground-water flow by 1985 (fig. 34). Flow from the regional recharge area in southern Mississippi and adjacent Louisiana continued outward in the same directions as during predevelopment, but pumpage has caused flow lines to turn parallel to the coast and toward the center of pumpage. Flow lines between the gulf and the center of pumpage changed direction due to the pumping, and flow from offshore now moves toward the center of pumpage at Baton Rouge. Horizontal flow volumes onshore between the pumping center and the gulf were substantially larger in 1985 than in predevelopment. By 1985, the vertical flow of water relative to the base of permeable zone B was reversed from its predevelopment direction. Pumping from the underlying permeable zone $C$ resulted in flow from permeable zone $B$ to permeable zone $C$.

The predevelopment direction of vertical flow between permeable zone $B$ and the overlying permeable zone A (fig. 33) was also reversed in these two pumping centers by ground-water development. Substantial quantities of water moved from the water table downward through permeable zone A into permeable zone B to supply pumpage from permeable zone $B$ and underlying permeable zones in 1985.

\section{MIDDLE CLAIBORNE AQUIFER}

Horizontal flow direction in the middle Claiborne aquifer changed very little in the Texas coastal uplands aquifer system but changed substantially in the Mississippi embayment aquifer system. Vertical flow relative to the base of the aquifer changed direction in southern Texas, northeastern Arkansas, southwestern Arkansas and adjacent parts of Louisiana, and in local areas in Mississippi (compare figs. 31 and 36).

By 1985, the direction of horizontal flow in the middle Claiborne aquifer of the Mississippi embayment aquifer system was toward major centers of pumpage in extreme southwestern Tennessee, southern Arkansas, and northern Louisiana (fig. 36). Flow relative to the base of the aquifer in northeastern Arkansas west of the pumping center in Tennessee was reversed from predevelopment; by 1985, flow was downward from the mid- dle Claiborne aquifer to the underlying lower Claiborne-upper Wilcox aquifer. Some horizontal flow paths in the lower Claiborne-upper Wilcox aquifer had an eastward component into Tennessee where flow was upward to the center of pumpage in the middle Claiborne aquifer. However, some of the areas where flow was downward from the middle Claiborne aquifer in northeastern Arkansas coincides with an area of downward flow across the base of the lower Claiborne-upper Wilcox aquifer to supply pumpage from underlying aquifers. The most widespread change in vertical flow direction related to pumping in the middle Claiborne aquifer occurred in the overlying upper Claiborne aquifer. By 1985, downward flow from the upper Claiborne aquifer to the middle Claiborne aquifer extended throughout most of the area where the upper Claiborne aquifer is present in Arkansas and Tennessee. Under predevelopment conditions, the flow was in the opposite direction, from the middle Claiborne aquifer upward to the upper Claiborne aquifer.

Flow lines converged toward pumping centers in northeastern Louisiana by 1985 . The point of convergence had moved to the south and slightly westward from the point of convergence under predevelopment conditions. Downward flow under predevelopment conditions in northwestern Louisiana had been reversed to upward flow relative to the base of the middle Claiborne aquifer throughout an area of about $70 \mathrm{mi}^{2}$ by 1985 .

Horizontal flow patterns changed little in the middle Claiborne aquifer of the Texas coastal uplands aquifer system from predevelopment to 1985 because there has been minimal pumping from the aquifer. However, by 1985 the vertical flow direction throughout an area of several hundred square miles in southern Texas had been reversed from predevelopment. By 1985, water flowed downward from the middle Claiborne aquifer to the lower Claiborne-upper Wilcox aquifer because of the large withdrawals from the lower Claiborne-upper Wilcox aquifer.

\section{GROUND-WATER BUDGET}

During 1985, regional recharge increased from about 2,900 $\mathrm{Mgal} / \mathrm{d}$ under simulated predevelopment conditions to about $9,600 \mathrm{Mgal} / \mathrm{d}$, and natural discharge decreased from about 2,900 Mgal/d to about $1,100 \mathrm{Mgal} / \mathrm{d}$ during the same time period (compare figs. 32 and 37). These changes are due to ground-water withdrawals which generally increased from the late 1800 's to about $8,900 \mathrm{Mgal} / \mathrm{d}$ during 1985 . About 76 percent of the ground water withdrawn during 1985 was derived from an increase in recharge, about 21 percent from a decrease in discharge, and about 3 percent 

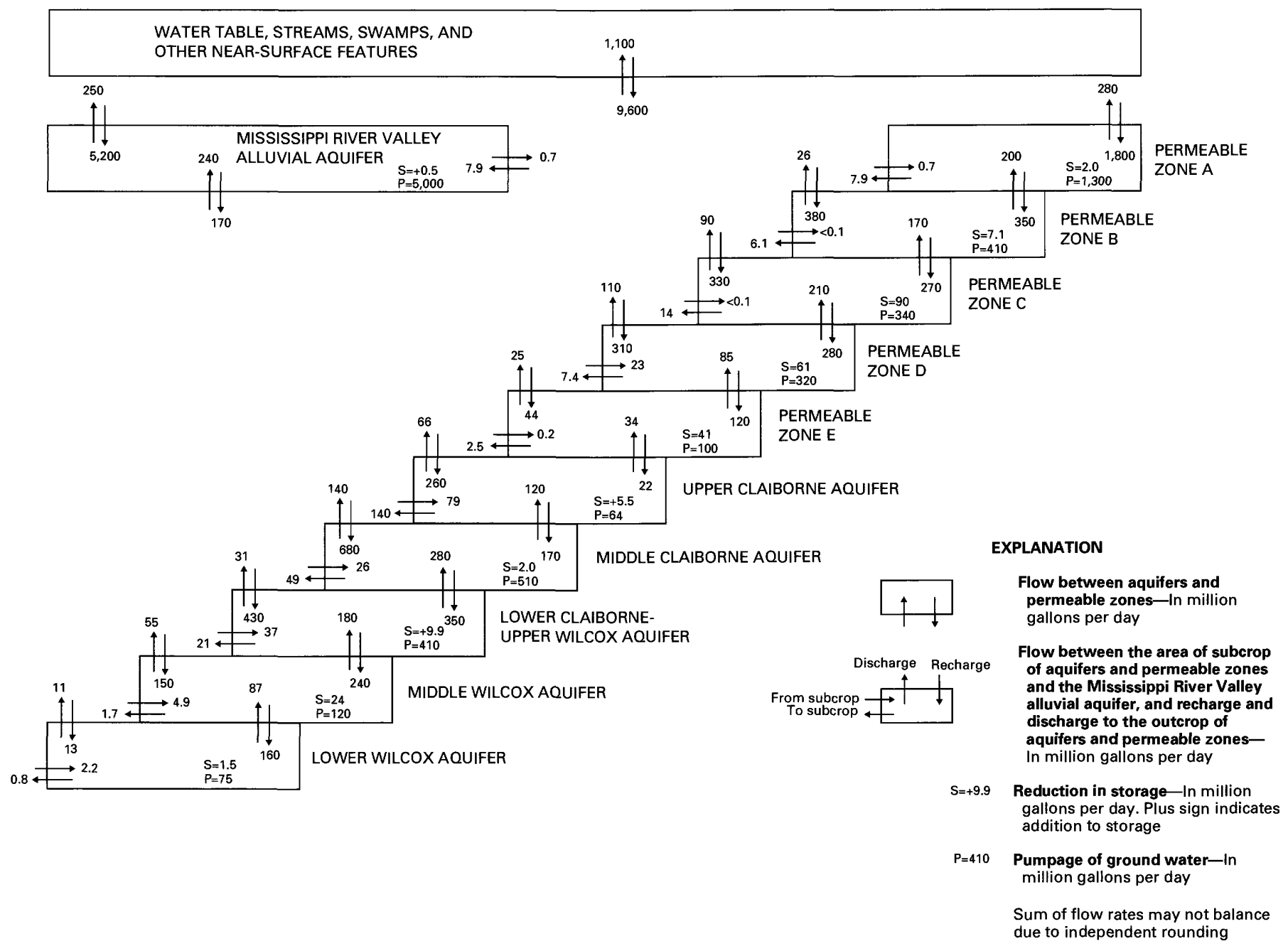

FIGURE 37.-Simulated 1987 ground-water budget from the regional-scale model.

from loss of aquifer system storage. Net simulated recharge to all aquifers and permeable zones except the Mississippi River Valley alluvial aquifer and permeable zone A was about 2,050 Mgal/d, or an increase from predevelopment by a factor of about 5 . Net simulated recharge to permeable zone A was about $1,480 \mathrm{Mgal} / \mathrm{d}$ compared to a net predevelopment discharge of about $300 \mathrm{Mgal} / \mathrm{d}$. The largest change in the ground-water budget was for the Mississippi River Valley alluvial aquifer, which had a net simulated recharge of about 5,000 Mgal/d during 1987 compared to a net predevelopment discharge of about $390 \mathrm{Mgal} / \mathrm{d}$. The change from net discharge to net recharge was because the Mississippi River Valley alluvial aquifer had more than one-half (about 4,900 Mgal/d) of the 1985 pumpage. Net recharge to other aquifers and permeable zones ranged from about $2 \mathrm{Mgal} / \mathrm{d}$ to the lower Wilcox aquifer to as much as $550 \mathrm{Mgal} / \mathrm{d}$ to the middle Claiborne aquifer. Part of the increase in regional recharge was derived from capture of discharge from the local flow system that was not simulated by the large-scale models. Net vertical flows were downward in all aquifers and permeable zones except for the upward flow from the upper Claiborne aquifer to permeable zone $E$ of the coastal lowlands aquifer system.

With the exception of permeable zone A, net simulated recharge to the permeable zones of the coastal lowlands aquifer system during the 1980's was least to permeable zone $\mathrm{E}$ and most to permeable zone B (Martin and Whiteman, in press; Ryder and Ardis, in press). The largest net vertical flow between permeable zones was from permeable zone A downward to permeable zone $\mathrm{B}$.

Net simulated recharge to the aquifers of the Texas coastal uplands aquifer system during the 1980's was least to the upper Claiborne aquifer and most to the lower Claiborne-upper Wilcox aquifer (Ryder and Ardis, in press). The largest net vertical flow between 


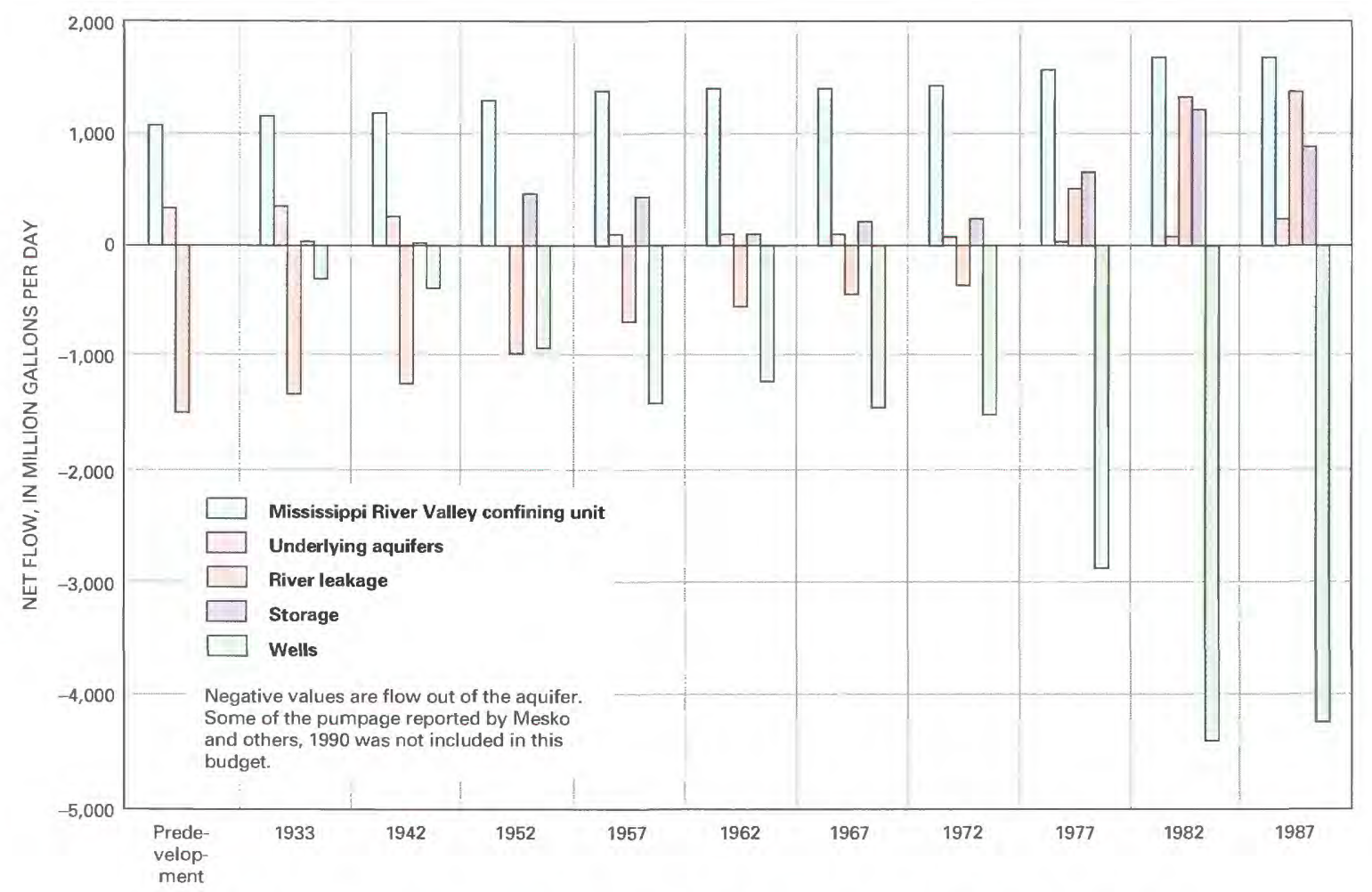

FIGURE 38.- Simulated ground-water budget for the Mississippi River Valley alluvial aquifer, predevelopment through 1987.

aquifers was from the middle Claiborne aquifer downward to the lower Claiborne-upper Wilcox aquifer.

Net simulated recharge to the aquifers of the Mississippi embayment aquifer system during the 1980's was least to the lower Wilcox aquifer and most to the middle Claiborne aquifer (Arthur and Taylor, in press). The largest net vertical flow between aquifers was from the upper Claiborne aquifer downward to the middle Claiborne aquifer. Net discharge to the Mississippi River Valley alluvial aquifer from all aquifers was reduced to about 14 percent of the predevelopment discharge, and net discharge from the upper Claiborne aquifer was reduced to about 3 percent of the predevelopment discharge.

The ground-water budget for the Mississippi River Valley alluvial aquifer is of interest because more than one-half of the 1985 withdrawals were from this aquifer, and the change in sources of water supplying the withdrawals gives a more detailed picture of the hydrology than the combined budgets for regional aquifer systems. Prior to development of the groundwater supply, the recharge through the surficial Mississippi River Valley confining unit (a locally recognized geohydrologic unit) and the flow upward from underlying units was discharged principally to the stream network of the Mississippi Alluvial Plain (fig. 38). Simulations indicate that discharge to the streams decreased as withdrawals increased, and by 1952 the volume pumped was about equal to the discharge to streams (Ackerman, 1996). As withdrawals continued to increase after 1952, the quantity of water discharged to streams continued to decrease until sometime between 1972 and 1977 when the inflow from the streams to the aquifer exceeded aquifer discharge to the streams. Recharge increased substantially after 1952 and was still the largest source of water to the aquifer, although the inflow from the streams was almost as large (fig. 38).

\section{DECREASE IN SATURATED THICKNESS}

Long-term decreases in saturated thickness have resulted from the withdrawal of ground water in the lower Claiborne-upper Wilcox aquifer in the Winter Garden area of southern Texas and in the Mississippi River Valley alluvial aquifer in eastern and central Arkansas. A rate of decrease in saturated thickness of about $1.5 \mathrm{ft} / \mathrm{yr}$ in the lower Claiborne-upper Wilcox aquifer was reported by Ryder and Ardis (in press) at a well in northeastern Zavala County, Texas, during the period 1965-85. The total decrease in saturated thick- 
ness was about $95 \mathrm{ft}$ since withdrawals began. By 1985, an area of about $240 \mathrm{mi}^{2}$ is estimated to have experienced a substantial decrease in saturated thickness. At this rate of decrease in saturated thickness, a total of $125 \mathrm{ft}$ of the original $200 \mathrm{ft}$ of saturated thickness would be dewatered within the next 20 years.

A rate of decrease in saturated thickness of about $2 \mathrm{ft} / \mathrm{yr}$ in the Mississippi River Valley alluvial aquifer at some locations in east-central Arkansas during the 1980's was noted by Ackerman (1996). By 1982, an area of about $300 \mathrm{mi}^{2}$ had simulated decreases in saturated thickness of from 40 to $60 \mathrm{ft}$ since withdrawals began. At current (1985) withdrawal rates, the original saturated thickness of about $100 \mathrm{ft}$ may be dewatered to the point that withdrawal rates cannot be sustained within the next 15 to 20 years.

Both areas noted above as having substantial decreases in saturated thickness are only a small part of the area underlain by the aquifers being pumped. However, they suggest that serious declines in pumpage could be caused by decreased saturated thickness locally and that perhaps increased effort is needed to quantify inflow and outflow at a local scale.

\section{LAND SUBSIDENCE}

Land subsidence probably has resulted from withdrawal of ground water throughout thousands of square miles of the Gulf Coastal Plain. Locally, up to $10 \mathrm{ft}$ of subsidence has been measured east of Houston, Texas, near Galveston Bay (Gabrysch and Coplin, 1990). Subsidence is difficult and expensive to measure; thus, it has been measured at only a few locations in the Gulf Coastal Plain. However, simulation of ground-water flow suggested that as much as one-half foot of land subsidence has resulted from ground-water withdrawals throughout tens of thousands of square miles of the Gulf Coastal Plain (Carr and others, 1985). The quantity of water released from clay beds as they are compacted due to the withdrawals from underlying aquifers may be a significant proportion of the ground water withdrawn during relatively short time periods of several decades. The rate of subsidence has decreased substantially in the area of maximum subsidence near Houston due to large decreases in pumpage. To the north and west of Houston, however, subsidence continued unabated during the 1980's as ground-water pumpage continued to increase.

The magnitude of subsidence due to ground-water withdrawals through the 1980's across the Gulf Coastal Plain was insignificant on a regional scale. Locally, in urban areas such as north and west of Houston, or in low-lying areas near the Gulf of Mexico, subsidence may continue to be a significant problem until withdrawal rates are reduced or centers of withdrawals are relocated, perhaps to areas that are farther inland and at higher altitudes or at shallower depths. Subsidence might become a significant regional problem if groundwater withdrawals of similar magnitude to those at Houston were to become widespread along the coast of Texas and Louisiana.

\section{SALTWATER ENCROACHMENT}

The effects of saltwater encroachment range from the necessity to relocate well fields to the slowly increasing chloride content in water from wells near the fresh-saltwater interface. The results of ground-water flow simulation suggest that location of pumping centers inland, away from the interface, does not stop the landward movement of saltwater and may result only in a longer span of time before increasing concentrations of chlorides are observed at the well fields.

The relocation of well fields is illustrated by the example of the city of Galveston, Texas. In the 1890's, the city's well field was moved inland to a location about 20 mi northwest of the city due to the lack of sufficient freshwater on Galveston Island. By the early 1940 's another well field was installed about $4 \mathrm{mi}$ farther inland because of an increase in the chloride concentration in the water withdrawn (Petitt and Winslow, 1955). These well fields, which obtain water from permeable zone A, supplied a substantial part of the water supply for the city of Galveston for about 40 to 45 years before surface water became the principal source of supply during the 1980's (Barbie and Locke, 1993). Chloride concentrations in water from both well fields decreased as withdrawals slowly declined beginning in the early 1970's.

Simulated flows in permeable zone A for 1987 are consistent with the observed chloride concentrations at the Galveston well fields. Horizontal flow lines near the shoreline of Galveston County are parallel to the shore (fig. 33), whereas the general direction of flow inland is toward the center of much larger ground-water withdrawals in the Houston area in Harris County. Vertical flow throughout Galveston County is downward relative to the base of permeable zone A (fig. 33), thus precluding upconing of saltwater from permeable zone B. However, horizontal flow in permeable zone B is from offshore (where the water has a larger concentration of dissolved solids than water in permeable zone A) across Galveston County toward the center of pumping in Harris County (fig. 34). Thus, chloride concentrations have probably increased with depth at the location of the Galveston well fields.

Nyman (1984) showed gradually increasing chloride concentrations in water from permeable zone A at several locations in southwestern Louisiana. Extensive pumping centers are located several miles inland from 
the shore (Mesko and others, 1990). Chloride concentrations increased at the rate of 5 to $15[(\mathrm{mg} / \mathrm{L}) / \mathrm{yr}]$ during1963-83 at locations between the shore and the center of maximum pumpage (Nyman, 1984). Simulated flow vectors in permeable zone A for 1987 (fig. 33) indicate large horizontal flow from near the shoreline inland toward the center of pumpage, and vertical flows were upward relative to the base of permeable zone $\mathrm{A}$; both conditions indicate the potential for the movement of saltwater from offshore and from below.

\section{POTENTIAL FOR GROUND-WATER DEVEL- OPMENT}

The aquifer systems of the Gulf Coastal Plain have a potential for further development of water supplies. The potential to increase regional recharge is substantial owing to the abundance of water in streams, lakes, swamps, and other surface-water bodies and to the hydraulic connection between the water table in outcrop areas and the confined part of aquifers and permeable zones. An analysis by Williamson and Grubb (in press) indicates that the aquifer systems could support withdrawals of as much as an additional $10,000 \mathrm{Mgal} / \mathrm{d}$. The local flow system as well as the regional flow system needs to be considered in locating pumping centers to minimize adverse impacts of additional withdrawals. Areas where the Mississippi River Valley alluvial aquifer has potential for further development were delineated by Ackerman (1996), and they are principally in northeastern Arkansas and southeastern Missouri, east-central Mississippi, and northeastern Louisiana. Areas of the Texas coastal uplands aquifer system with potential for further development were delineated by Ryder and Ardis (in press) and are principally in and near aquifer outcrop areas. Ryder and Ardis (in press) reported that the potential for development generally increases from west to east. The most favorable conditions for further development of ground-water supplies in the coastal lowlands aquifer system are generally in the upper permeable zones. Areas with potential for further development in the coastal lowlands aquifer system have been delineated by Martin and Whiteman (in press), and Ryder and Ardis (in press).

Many factors work in concert to determine the potential for the development of large quantities of ground water at any specific location. An example from Arthur and Taylor (in press) illustrates the effect of a regional confining bed. At Marianna, Arkansas, the lower Claiborne confining unit is present between the middle Claiborne aquifer and the lower Claiborne-upper Wilcox aquifer, whereas at Wynne, Arkansas, which is about $30 \mathrm{mi}$ to the north of Mari- anna, the confining unit is not present. Simulation of hypothetical ground-water withdrawals of $40 \mathrm{Mgal} / \mathrm{d}$ from a $100-\mathrm{mi}^{2}$ area underlain by the middle Claiborne aquifer resulted in about $60 \mathrm{ft}$ more drawdown after 13 years pumping at Marianna than at Wynne.

\section{REFERENCES}

Ackerman, D.J., 1987a, Generalized potentiometric surface of the aquifers in the Cockfield Formation, southeastern Arkansas, spring 1980: U.S. Geological Survey Water-Resources Investigations Report 87-4212, map, scale 1:500,000, 1 sheet.

$-1987 \mathrm{~b}$, Generalized potentiometric surface of the Sparta-Memphis aquifer, eastern Arkansas, spring 1980: U.S. Geological Survey Water-Resources Investigations Report $87-4282$, map, scale 1:500,000, 1 sheet.

-1989a, Hydrology of the Mississippi River Valley alluvial aquifer, south-central United States-A preliminary assessment of the regional flow system: U.S. Geological Survey Water-Resources Investigations Report 88-4028, $74 \mathrm{p}$.

1989b, Potentiometric surfaces of the Mississippi River Valley alluvial aquifer in eastern Arkansas, spring 1972 and 1980: U.S. Geological Survey Water-Resources Investigations Report 884075, map, scale 1:500,000, 1 sheet.

-1996, Hydrology of the Mississippi River Valley alluvial aquifer, south-central United States: U.S. Geological Survey Professional Paper 1416-D, $56 \mathrm{p}$.

Albin, D.R., 1964, Geology and ground-water resources of Bradley, Calhoun, and Ouachita Counties, Arkansas: U.S. Geological Survey Water-Supply Paper $1779-\mathrm{G}, 32 \mathrm{p}$.

Anders, R.B., and Naftel, W.L., 1962, Pumpage of ground water and fluctuation of water levels in the Houston district, and the Baytown-La Porte area, Texas, 1957-61: Texas Water Commission Bulletin 6211, 52 p.

Andrews, D.I., 1960, The Louann Salt and its relationship to gulf coast salt domes: Gulf Coast Association of Geological Societies, Transactions, v. 10, p. 215-240.

Arthur, J.K., and Taylor, R.E., 1986, Mississippi embayment aquifer system in Mississippi-Geohydrologic data compilation for flow model simulation: American Water Resources Association, Water Resources Bulletin, v. 22, no. 6, p. 1021-1029.

-1990, Definition of geohydrologic framework and preliminary simulation of ground-water flow in the Mississippi embayment aquifer system, Gulf Coastal Plain, United States: U.S. Geological Survey Water-Resources Investigations Report 86-4364, 97 p.

in press, Ground-water flow analysis of the Mississipp1 embayment aquifer system, south-central United States: U.S. Geological Survey Professional Paper 1416-I.

Baker, E.T., Jr., and Wall, J.R., 1976, Summary appraisals of the Nation's ground-water resources-Texas-Gulf region: U.S. Geological Survey Professional Paper 813-F, 29 p.

Barbie, D.L., and Locke, G.L., 1993, Ground-water withdrawals, water levels, and ground-water quality in the Houston District, Texas, with emphasis on 1985-89: U.S. Geological Survey WaterResources Investigations Report 92-4180, 28 p.

Beckman, J.D., and Williamson, A.K., 1990, Salt-dome locations in the Gulf Coastal Plain, south-central United States: U.S. Geological Survey Water-Resources Investigations Report 90-4060, 44 p.

Bedinger, M.S., and Sniegocki, R.T., 1976, Summary appraisals of the Nation's ground-water resources-Arkansas-White-Red region: U.S. Geological Survey Professional Paper 813-H, 31 p.

Bennett, G.D., 1979, Regional ground-water systems analysis: U.S. Army Corps of Engineers, Water Support Center, Fort Belvoir, Virginia, Water Spectrum, v. 11, no. 4, p. 36-42. 
Boswell, E.H., and Arthur, J.K., 1988, Generalized potentiometric surface of shallow aquifers in southern Mississippi, 1982: U.S. Geological Survey Water-Resources Investigations Report 87-4257, map, scale 1:500,000, 1 sheet.

Boswell, E.H., Cushing, E.M., and Hosman, R.L., 1968, Quaternary aquifers in the Mississippi embayment, with a discussion of Quality of the water by H.G. Jeffery: U.S. Geological Survey Professional Paper 448-E, 15 p.

Boswell, E.H., Moore, G.K, and MacCary, L.M., 1965, Cretaceous aquifers in the Mississippi embayment, with a discussion of Quality of the water by H.G. Jeffery: U.S. Geological Survey Professional Paper $448-\mathrm{C}, 37 \mathrm{p}$.

Brahana, J.V., 1982, Two-dimensional digital ground-water model of the Memphis Sand and equivalent units, Tennessee, Arkansas, Mississippi: U.S. Geological Survey Open-File Report 82-99, $62 \mathrm{p}$.

1987, The role of multilayer model in refining understanding of deep regional ground-water flow in a tectonically active area, in Proceedings, Solving Ground Water Problems with Models Conference and Exposition: Dublin, Ohio, National Water Well Association, Denver, Colo., February 10-12, 1987, v. 2, p. 10511070.

Brahana, J.V., and Mesko, T.O., 1988, Hydrogeology and preliminary assessment of regional flow in the Upper Cretaceous and adjacent aquifers, northern Mississippi embayment: U.S. Geological Survey Water-Resources Investigations Report 87-4000, 65 p.

_-in press, Hydrology of the McNairy-Nacatoch and adjacent aquifers in the northern Mississippi embayment: U.S. Geological Survey Water-Resources Investigations Report 96-4108.

Brahana, J.V., Mesko, T.O., Busby, J.F., and Kraemer, T.F., 1985, Ground-water quality data from the northern Mississippi embayment-Arkansas, Missouri, Kentucky, Tennessee, and Mississippi: U.S. Geological Survey Open-File Report 85-683, $15 \mathrm{p}$.

Broom, M.E., 1965, Ground-water resources of Camp, Franklin, Morris, and Titus Counties, Texas: Texas Water Commission Bulletin $6517,159 \mathrm{p}$.

Broom, M.E., and Lyford, F.P., 1981, Alluvial aquifer of the Cache and St. Francis River basins, northeastern Arkansas: U.S. Geological Survey Open-File Report 81-476, 48 p.

Broom, M.E., and Reed, J.E., 1973, Hydrology of the Bayou Bartholomew alluvial-aquifer stream system, Arkansas: U.S. Geological Survey Open-File Report 73-0034, 91 p.

Callahan, J.A., Skelton, John, Everett, D.E., and Harvey, E.J., 1963, Available water for industry-Adams, Claiborne, Jefferson, and Warren Counties, Mississippi: Mississippi Industrial and Technological Research Commission Bulletin 63-1, 48 p.

Carr, J.E., Meyer, W.R., Sandeen, W.M., and McLane, I.R., 1985, Digital models for simulation of ground-water hydrology of the Chicot and Evangeline aquifers along the Gulf Coast of Texas: Texas Department of Water Resources Report 289, 101 p.

Case, H.L., 1979, Ground-water resources of Washington Parish, Louisiana: Louisiana Department of Transportation and Development, Office of Public Works Water-Resources Technical Report $18,33 \mathrm{p}$.

Cederstrom, D.J., Boswell, E.H., and Tarver, G.R., 1979, Summary appraisals of the Nation's ground-water resources-South Atlantic-Gulf region: U.S. Geological Survey Professional Paper 813-O, $35 \mathrm{p}$.

Charbeneau, R.J., and Wright, S.G., 1983, Hydrologic site selection for mining of deep basin lignite in Texas: The University of Texas at Austin, Center for Research in Water Resources, Technical Report CRWR 198, 113 p.

Counts, H.B., 1957, Ground-water resources of parts of Lonoke, Prairie, and White Counties, Arkansas: Arkansas Geological and Conservation Commission Water Resources Circular 5, 58 p.
Crider, A.F., and Johnson, L.C., 1906, Summary of the undergroundwater resources of Mississippi: U.S. Geological Survey WaterSupply Paper 159, $86 \mathrm{p}$.

Criner, J.H., and Parks, W.S., 1976, Historic water-level changes and pumpage from the principal aquifers of the Memphis area, Tennessee-1886-1975: U.S. Geological Survey Water-Resources Investigations Report 76-67, $45 \mathrm{p}$.

Cushing, E.M., Boswell, E.H., Speer, P.R., and Hosman, R.L., 1970, Availability of water in the Mississippi embayment: U.S. Geological Survey Professional Paper 448-A, 13 p.

Dalsin, G.J., and Bettandorff, J.M., 1976, Water for industrial and agricultural development in Coahoma, DeSoto, Panola, Quitman, Tate, and Tunica Counties, Mississippi: Mississippi Research and Development Center Bulletin, $87 \mathrm{p}$.

Davis, M.E., Sanford, T.H., Jr., and Jefferson, P.O., 1980, Water availability and geology of Sumter County, Alabama: Geological Survey of Alabama and State Oil and Gas Board Special Map $158,69 \mathrm{p}$.

Davis, R.W., 1965, Availability of ground water in the Mayfield quadrangle, in the Jackson Purchase region, Kentucky: U.S. Geological Survey Hydrologic Investigations Atlas HA-164, scale 1:24,000, 1 sheet.

Deussen, Alexander, and Dole, R.B., 1916, Ground water in La Salle and McMullen Counties, Texas, in Contributions to the hydrology of the United States, 1915: U.S. Geological Survey WaterSupply Paper 375-G, p. 141-177.

Engler, Kyle, Bayley, F.H., III, and Sniegocki, R.T., 1963, Studies of artificial recharge in the Grand Prairie region, Arkansas-Environment and history: U.S. Geological Survey Water-Supply Paper 1615-A, p. A1-A32.

Engler, Kyle, Thompson, D.G., and Kazmann, R.G., 1945, Groundwater supplies for rice irrigation in the Ground Prairie region, Arkansas-Arkansas University Agricultural Experiment Station Bulletin 457, 56 p.

Fenneman, N.M., 1938, Physiography of eastern United States: New York, McGraw-Hill Book Company, $714 \mathrm{p}$.

Fogg, G.E., Jr., Seni, S.J., and Kreitler, C.W., 1983, Three-dimensional ground-water modeling in depositional systems, Wilcox Group, Oakwood Salt Dome area, east Texas: The University of Texas at Austin Bureau of Economic Geology Report of Investigations $133,55 \mathrm{p}$.

Follett, C.R., 1947, Ground-water resources of Brazoria County, Texas: Texas Board of Water Engineers Report M 19, 103 p.

Follett, C.R., 1974, Ground-water resources of Brazos and Burleson Counties, Texas: Texas Water Development Board Report 185, $196 \mathrm{p}$.

Fuller, M.L., 1904, Contributions to the hydrology of the eastern United States, 1903: U.S. Geological Survey Water-Supply Paper 102,522 p.

Gabrysch, R.K., 1969, Land-surface subsidence in the HoustonGalveston region, Texas, in Land subsidence: International Symposium on Land Subsidence, International Association of Hydrological Sciences, Proceedings, Publication 88, p. 43-54.

1977, Land-surface subsidence in the Houston-Galveston region, Texas: Land Subsidence Symposium, International Association of Hydrological Sciences, Publication 121, p. 16-24.

1982, Ground-water withdrawals and land-surface subsidence in the Houston-Galveston region, Texas, 1906-80: U.S. Geological Survey Open-File Report 82-0571, 68 p.

1984, Ground-water withdrawals and changes in water levels in the Houston District, Texas, 1975-79: Texas Department of Water Resources Report 286, 42 p.

Gabrysch, R.K., and Bonnet, C.W., 1975, Land-surface subsidence in the Houston-Galveston region, Texas: Texas Water Development Board Report 188, 19 p. 
Gabrysch, R.K., and Coplin, L.S., 1990, Land-surface subsidence resulting from ground-water withdrawals in the HoustonGalveston region, Texas, through 1987: Harris-Galveston Coastal Subsidence District Report of Investigations 90-01, 53 p.

Galloway, W.E., 1989, Genetic stratigraphic sequences in basin analysis II. Application to northwest Gulf of Mexico Cenozoic basin: American Association of Petroleum Geologists Bulletin, v. 73, no. 2, p. 143-154.

Garza, Sergio, 1974, Projected effects of the proposed Tennessee Colony Reservoir on ground-water conditions in the Carrizo-Wilcox aquifer and Trinity River alluvium, Trinidad-Oakwood area, Texas: U.S. Geological Survey Open-File Report 74-0297, 33 p.

Garza, Sergio, Jones, B.D., and Baker, E.T., Jr., 1987, Approximate potentiometric surfaces for the aquifers of the Texas coastal uplands system, 1980: U.S. Geological Survey Hydrologic Investigations Atlas HA-704, scale 1:1,500,000, 1 sheet.

Gebert, W.A., Graczyk, D.J., and Krug, W.R., 1987, Average annual runoff in the United States, 1951-80: U.S. Geological Survey Hydrologic Investigations Atlas $\mathrm{HA}-710,1$ plate, scale 1:500,000.

Glenn, L.C., 1906, Underground waters of Tennessee and Kentucky west of the Tennessee River and of an adjacent area in Illinois: U.S. Geological Survey Water-Supply Paper 164, 173 p.

Godson, R.H., 1981, Digital terrain map of the United States: U.S. Geological Survey Miscellaneous Investigations Map I-1318, scale $1: 7,500,000,1$ sheet.

Groschen, G.E., 1985, Simulated effects of projected pumping on the availability of freshwater in the Evangeline aquifer in an area southwest of Corpus Christi, Texas: U.S. Geological Survey Water-Resources Investigations Report 85-4182, 103 p.

Grubb, H.F., 1984, Planning report for the Gulf Coast Regional Aquifer-System Analysis, Gulf of Mexico Coastal Plain, United States: U.S. Geological Survey Water-Resources Investigations Report $84-4219,30 \mathrm{p}$.

-1985, Gulf Coast Regional Aquifer-System Analysis, an overview, in Smerdon, E.T., and Jordan, W.R., eds., Issues in groundwater management: University of Texas at Austin, Center for Research in Water Resources, Symposium Number Twelve, San Antonio, Texas, October 29-31, 1984, Proceedings, p. 69-91.

1986a, Gulf Coast Regional Aquifer-System Analysis-A Mississippi perspective: U.S. Geological Survey Water-Resources Investigations Report 86-4162, 22 p.

1986b, Gulf Coastal Plain Regional Aquifer-System Study, in Sun, R.J., ed., Regional Aquifer-System Analysis Program of the U.S. Geological Survey-Summary of projects, 1978-84: U.S. Geological Survey Circular 1002, p. 152-161.

1987, Overview of the Gulf Coast Regional Aquifer-System Analysis, in Vecchioli, John, and Johnson, A.I., eds., Regional Aquifer Systems of the United States, Aquifers of the Atlantic and Gulf Coastal Plain: American Water Resources Association, Monograph no. 9, p. 101-118.

1992, An overview of the Gulf Coast Regional Aquifer-System Analysis, 1991, in Hotchkiss, W.R., and Johnson, A.I., eds., Regional Aquifer Systems of the United States, Aquifers of the Southern and Eastern States: American Water Resources Association, Monograph no. 17, p. 5-41.

Grubb, H.F., and Arthur, J.K., 1991, Gulf Coast Regional AquiferSystem Analysis-A Kentucky perspective: U.S. Geological Survey Water-Resources Investigations Report 90-4138, $28 \mathrm{p}$.

Grubb, H.F., and Carrillo R., J.J., 1988, Region 23, Gulf of Mexico Coastal Plain, in Back, W., Rosenshein, J.S., and Seaber, P.R., eds. Hydrogeology: Boulder, Colorado, Geological Society of America, The Geology of North America, v. O-2, p. 219-228.

Halbouty, M.T., 1979, Salt domes, Gulf Region, United States and Mexico (2d ed.): Houston, Gulf Publishing Company, 561 p.
Hansen, A.J., Jr., 1967, Availability of ground water in the Cayce quadrangle, Jackson Purchase region, Kentucky-Tennessee: U.S. Geological Survey Hydrologic Investigations Atlas HA-180, scale $1: 24,000,1$ sheet.

Harris, G.D., 1904, Underground waters of southern Louisiana, with discussions of their uses for water supplies and for rice irrigation by M.L. Fuller: U.S. Geological Survey Water-Supply Paper 101, $98 \mathrm{p}$.

Henry, D.C., Galloway, W.E., and Smith, G.E., 1982, Considerations in the extraction of uranium from a fresh-water aquifer-Miocene Oakville Sandstone, south Texas: The University of Texas at Austin, Bureau of Economic Geology Report of Investigations $126,36 \mathrm{p}$.

Hewitt, F.A., Baker, R.C., and Billingsley, G.A., 1949, Ground-water resources of Ashley County, Arkansas: Arkansas University Institute of Science and Technology, Research Series 16, 35 p.

Hill, R.T., 1901, Geography and geology of the Black and Grand Prairies, Texas: U.S. Geological Survey Twenty-first Annual Report, part VII, $666 \mathrm{p}$.

Hosman, R.L., 1982, Outcropping Tertiary units in southern Arkansas: U.S. Geological Survey Miscellaneous Investigations Series, Map I-1405, scale 1:250,000, 1 sheet.

1988, Geohydrologic framework of the Gulf Coastal Plain: U.S. Geological Survey Hydrologic Investigations HA-Atlas 695, scale 1:2,500,000, 2 sheets.

_1996, Regional stratigraphy and subsurface geology of Cenozoic deposits, Gulf Coastal Plain, south-central United States: U.S. Geological Survey Professional Paper 1416-G, 35 p.

Hosman, R.L., Long, A.T., Lambert, T.W., and others, 1968, Tertiary aquifers in the Mississippi embayment, with discussion of Quality of the water by H.G. Jeffery: U.S. Geological Survey Professional Paper 448-D, 29 p.

Hosman, R.L., and Weiss, J.S., 1991, Geohydrologic units of the Mississippi embayment and Texas coastal uplands aquifer systems, south-central United States: U.S. Geological Survey Professional Paper 1416-B, $19 \mathrm{p}$.

Huntzinger, T.L., Whiteman, C.D., Jr., and Knochenmus, D.D., 1985, Simulation of ground-water movement in the "1,500- and 1,700foot" aquifer of the Baton Rouge area, Louisiana: Louisiana Department of Transportation and Development, Office of Public Works Water Resources Technical Report 34, 52 p.

Jones, P.H., Hendricks, E.L., Irelan, Burdge, and others, 1956, Water resources of southwestern Louisiana: U.S. Geological Survey Water-Supply Paper 1364, $460 \mathrm{p}$.

Jorgensen, D.G., 1973, Analog-model studies of the effects of recharge wells along the Houston ship channel on potentiometric surfaces of the Chicot and Evangeline aquifers, Houston, Texas: U.S. Geological Survey Open-File Report 73-0138, 2 sheets. 1975, Analog-model studies of ground-water hydrology in the Houston District, Texas: Texas Water Development Board Report 190, 84 p.

1977, Salt-water encroachment in aquifers near the Houston ship channel, Texas: U.S. Geological Survey Open-File Report 76-781, $46 \mathrm{p}$.

Jorgensen, D.G., and Gabrysch, R.K., 1974, Simulated water-level changes resulting from proposed changes in ground-water pumping in the Houston, Texas, area: U.S. Geological Survey Open-File Report 75-0020, 3 sheets.

Klemt, W.B., Duffin, G.L., and Elder, G.R., 1976, Ground-water resources of the Carrizo aquifer in the Winter Garden area of Texas, Volume 1: Texas Water Development Board Report $210,66 \mathrm{p}$.

Kuiper, L.K., 1983, A numerical procedure for the solution of the steady-state variable density groundwater flow equation: Water Resources Research, v. 19, no. 1, p. 234-240. 
1985, Documentation of a numerical code for the simulation of variable density ground-water flow in three dimensions: U.S. Geological Survey Water-Resources Investigations Report 844302, 90 p.

1986, A comparison of several methods for the solution of the inverse problem in two-dimensional steady state groundwater flow modeling: Water Resources Research, v. 22, no. 5, p. 705-714.

1987a, A comparison of iterative methods as applied to the solution of the nonlinear three-dimensional groundwater flow equation: Society for lndustrial and Applied Mathematics, Journal on Scientific and Statistical Computing, v. 8, no. 4, p. 521-528.

-1987b, Computer program for solving ground-water flow equations by the preconditioned conjugate gradient method: U.S. Geological Survey Water-Resources Investigations Report 874091, 34 p.

_-1994, Nonlinear-regression flow model, gulf coast aquifer systems, south-central United States: U.S. Geological Survey WaterResources Investigations Report 93-4020, $171 \mathrm{p}$.

Kuniansky, E.L., 1989, Geohydrology and simulation of ground-water flow in the "400-foot", "600-foot", and adjacent aquifers, Baton Rouge area, Louisiana: Louisiana Department of Transportation and Development, Water-Resources Technical Report no. 49, $90 \mathrm{p}$.

Lambert, T.W., 1968, Availability of ground water in the parts of the Wickliffe and Wickliffe NW quadrangles in Jackson Purchase region, Kentucky: U.S. Geological Survey Hydrologic lnvestigations Atlas HA-185, scale 1:24,000, 1 sheet.

Lamonds, A.G., Hines, M.S., and Plebuch, R.O., 1969, Water resources of Randolph and Lawrence Counties, Arkansas: U.S. Geological Survey Water-Supply Paper 1879-B, p. B1-B45.

Livingston, Penn, and Bridges, T.W., 1936, Ground-water resources of Kleberg County, Texas: U.S. Geological Survey Water-Supply Paper 773-D, p. 197-232.

Lonsdale, J.T., 1935, Geology and ground-water resources of Atascosa and Frio Counties, Texas: U.S. Geological Survey Water-Supply Paper 676, $90 \mathrm{p}$

Lonsdale, J.T., and Day, J.R., 1937, Geology and ground-water resources of Webb County, Texas: U.S. Geological Survey WaterSupply Paper 778, $104 \mathrm{p}$.

Ludwig, A.H., 1972, Water resources of Hempstead, Lafayette, Little River, Miller, and Nevada Counties, Arkansas: U.S. Geological Survey Water-Supply Paper 1998, 41 p.

Ludwig, A.H., and Terry, J.E., 1980, Methods and applications of digital-model simulation of the Red River alluvial aquifer, Shreveport to the mouth of the Black River, Louisiana: U.S. Geological Survey Water-Resources Investigations Report 79-114, 109 p.

MacCary, L.M., 1964, Availability of ground water in the Hazel quadrangle, Kentucky-Tennessee: U.S. Geological Survey Hydrologic Investigations Atlas HA-124, scale 1:24,000, 1 sheet.

-1984, Relation of formation factor to depth of burial in aquifers along the Texas Gulf Coast: National Water Well Association, Conference on Surface and Borehole Geophysical Methods in Ground-Water Investigations, San Antonio, Texas, February 6-9, 1984, Proceedings, p. 722-742.

MacCary, L.M., and Davis, R.W. 1966, Availability of ground water in the Westplains quadrangle, Jackson Purchase region, Kentucky: U.S. Geological Survey Hydrologic lnvestigations Atlas HA-166, scale 1:24,000, 1 sheet.

Maher, J.C., 1941, Ground-water resources of Grant and La Salle Parishes, Louisiana: Louisiana Department of Minerals Geological Bulletin 20,95 p

Marie, J.R., 1971, Ground-water resources of Avoyelles Parish, Louisiana: Louisiana Department of Conservation, Louisiana Geological Survey, and Louisiana Department of Public Works WaterResources Bulletin 15,70 p.
Martin, Angel, Jr., and Whiteman, C.D., Jr., 1985a, Generalized potentiometric surface of aquifers of Pleistocene age, southern Louisiana, 1980: U.S. Geological Survey Water-Resources Investigations Report 84-4331, map, scale 1:500,000, 1 sheet.

1985b, Generalized potentiometric surface of the Evangeline and equivalent aquifers in Louisiana, 1980: U.S. Geological Survey Water-Resources Investigations Report 84-4359, map, scale $1: 500,000,1$ sheet.

1986, Generalized potentiometric surface of the Catahoula aquifer in central Louisiana, 1980: U.S. Geological Survey WaterResources Investigations Report 86-4059, map, scale 1:500,000, 1 sheet.

-1989, Geohydrology and regional ground-water flow of the coastal lowlands aquifer system in parts of Louisiana, Mississippi, Alabama, and Florida-A preliminary analysis: U.S. Geological Survey Water-Resources lnvestigations Report 88-4100, 88 p.

1990, Calibration and sensitivity analysis of a ground-water flow model of the coastal lowlands aquifer system in parts of Louisiana, Mississippi, Alabama, and Florida: U.S. Geological Survey Water-Resources Investigations Report 89-4189, $54 \mathrm{p}$.

-in press, Hydrology of the coastal lowlands aquifer system in parts of Alabama, Florida, Louisiana, and Mississippi: U.S. Geological Survey Professional Paper 1416-H.

Martin, Angel, Jr., Whiteman, C.D., Jr., and Becnel, M.J., 1988, Generalized potentiometric surfaces of the upper and lower Jasper and equivalent aquifers in Louisiana, 1984: U.S. Geological Survey Water-Resources Investigations Report 87-4139, map, scale 1:500,000, 2 sheets.

Mason, C.C., 1960, Geology and ground-water resources of Dimmit County, Texas: Texas Board of Water Engineers Bulletin 6003, $235 \mathrm{p}$.

Matson, G.C., and Sanford, Samuel, 1913, Geology and ground waters of Florida: U.S. Geological Survey Water-Supply Paper $319,445 \mathrm{p}$.

Mesko, T.O., 1988, Subsurface geology of Paleozoic, Mesozoic, and Cenozoic units in southeast Missouri: U.S. Geological Survey Miscellaneous Investigations Series, Map I-1875, scale 1:500,000, 2 sheets.

1990, Geohydrology and water quality of Cenozoic and Mesozoic units in southeast Missouri: U.S. Geological Survey Hydrologic Investigations Atlas HA-719, scale 1:1,000,000, 2 sheets.

Mesko, T.O., Williams, T.A., Ackerman, D.J., and Williamson, A.K., 1990, Ground-water pumpage from the gulf coast aquifer systems, 1960-85, south-central United States: U.S. Geological Survey Water-Resources lnvestigations Report 89-4180, 177 p.

Meyer, R.R., and Turcan, A.N., Jr., 1955, Geology and ground-water resources of the Baton Rouge area, Louisiana: U.S. Geological Survey Water-Supply Paper 1296, 138 p.

Meyer, W.R., and Carr, J.E., 1979, A digital model for simulation of ground-water hydrology in the Houston area, Texas: Texas Department of Water Resources LP-103, 133 p.

Morgan, C.O., 1961, Ground-water conditions in the Baton Rouge area, 1954-59, with special reference to increased pumpage: Louisiana Department of Conservation, Louisiana Geological Survey, and Louisiana Department of Public Works WaterResources Bulletin 2,78 p.

Newton, J.G., Sutcliffe, Horace, Jr., and LaMoreaux, P.E., 1961, Geology and ground-water resources of Marengo County, Alabama: Geological Survey of Alabama and State Oil and Gas Board County Report 5, 443 p.

Nyman, D.J., 1984, The occurrence of high concentrations of chloride in the Chicot aquifer system of southwestern Louisiana: Louisiana Department of Transportation and Development, Office of Public Works, Water-Resources Technical Report 33, 75 p. 
Parks, W.S., and Carmichael, J.K., 1989, Geology and ground-water resources of the Fort Pillow Sand in western Tennessee: U.S. Geological Survey Water-Resources Investigations Report $89-4120,20$ p.

1990a, Altitude of potentiometric surface, fall 1985, and historic water-level changes in the Memphis aquifer in western Tennessee: U.S. Geological Survey Water-Resources lnvestigations Report 88-4180, 8 p.

-1990b, Geology and ground-water resources of the Cockfield Formation in western Tennessee: U.S. Geological Survey WaterResources Investigations Report 88-4181, 17 p.

- 1990c, Geology and ground-water resources of the Memphis Sand in western Tennessee: U.S. Geological Survey WaterResources Investigations Report 88-4182, 30 p.

-1990d, Altitude of potentiometric surface, fall 1985, and historic water-level changes in the Fort Pillow aquifer in western Tennessee: U.S. Geological Survey Water-Resources Investigations Report 89-4048, 8 p.

Parks, W.S., Carmichael, J.K., and Graham, D.D., 1985, Preliminary assessment of ground-water resources of Lauderdale County, Tennessee: U.S. Geological Survey Water-Resources Investigations Report 84-4104, 35 p.

Payne, J.N., 1968, Hydrologic significance of the lithofacies of the Sparta Sand in Arkansas, Louisiana, Mississippi, and Texas: U.S. Geological Survey Professional Paper 569-A, $17 \mathrm{p}$.

1970, Geohydrologic significance of lithofacies of the Cockfield Formation of Louisiana and Mississippi and of the Yegua Formation of Texas: U.S. Geological Survey Professional Paper 569-B, 14 p.

1972, Hydrologic significance of lithofacies of the Cane River Formation or equivalents of Arkansas, Louisiana, Mississippi, and Texas: U.S. Geological Survey Professional Paper 569-C, 17 p. 1975, Geohydrologic significance of lithofacies of the Carrizo Sand of Arkansas, Louisiana, and Texas and the Meridian Sand of Mississippi: U.S. Geological Survey Professional Paper 569-D, $11 \mathrm{p}$.

Petitt, B.M., Jr., and Winslow, A.G., 1955, Geology and ground-water resources of Galveston County, Texas: Texas Board of Water Engineers Bulletin 5502, 221 p.

Pettijohn, R.A., 1986, Processing water-chemistry data, gulf coast aquifer systems, south-central United States, with a summary of dissolved-solids concentrations and water types: U.S. Geological Survey Water-Resources Investigations Report 86-4186, 42 p.

-1988, Dissolved-solids concentrations and primary water types, gulf coast aquifer systems, south-central United States: U.S. Geological Survey Hydrologic Investigations Atlas HA-706, scale $1: 5,000,000,2$ sheets.

-1996, Geochemistry of ground-water in the gulf coast aquifer systems, south-central United States: U.S. Geological Survey Water-Resources Investigations Report 96-4107, $158 \mathrm{p}$.

Pettijohn, R.A., Busby, J.F., and Beckman, J.D., 1992, Properties and chemical constituents in ground water from the Mississippi River Valley alluvial aquifer and permeable zone A (Holocene-upper Pleistocene deposits) south-central United States: U.S. Geological Survey Water-Resources Investigations Report 91-4149, scale 1:3,500,000, 5 sheets.

1993a, Properties and chemical constituents in ground water from the lower Wilcox aquifer, Mississippi embayment aquifer system, south-central United States: U.S. Geological Survey Water-Resources Investigations Report 93-4071, scale 1:3,500,000, 5 sheets.

1993b, Properties and chemical constituents in ground water from the middle Wilcox aquifer, gulf coast regional aquifer systems, south-central United States: U.S. Geological Survey Water-
Resources lnvestigations Report 93-4070, scale 1:3,500,000, 5 sheets.

1993c, Properties and chemical constituents in ground water from permeable zone $\mathrm{D}$ (middle Miocene deposits), coastal lowlands aquifer system, south-central United States: U.S. Geological Survey Water-Resources lnvestigations Report 92-4105, scale $1: 3,500,000,5$ sheets.

Pettijohn, R.A., Busby, J.F., and Cervantes, M.A., 1993a, Properties and chemical constituents in ground water from permeable zone $C$ (lower Pliocene-upper Miocene deposits), coastal lowlands aquifer system, south-central United States: U.S. Geological Survey Water-Resources Investigations Report 91-4151, scale 1:3,500,000, 5 sheets.

1993b, Properties and chemical constituents in ground water from the lower Claiborne-upper Wilcox aquifer, gulf coast regional aquifer systems, south-central United States: U.S. Geological Survey Water-Resources Investigations Report 92-4102, scale 1:3,500,000, 5 sheets.

1993c, Properties and chemical constituents in ground water from the middle Claiborne aquifer, gulf coast regional aquifer systems, south-central United States: U.S. Geological Survey Water-Resources Investigations Report 92-4104, scale 1:3,500,000, 5 sheets.

Pettijohn, R.A., Busby, J.F., and Layman, T.B., 1993a, Properties and chemical constituents in ground water from the upper Claiborne aquifer, gulf coast regional aquifer systems, south-central United States: U.S. Geological Survey Water-Resources Investigations Report 91-4150, scale 1:3,500,000, 5 sheets.

1993b, Properties and chemical constituents in ground water from permeable zone B (lower Pleistocene-upper Pliocene deposits), coastal lowlands aquifer system, south-central United States: U.S. Geological Survey Water-Resources Investigations Report 91-4152, scale 1:3,500,000, 5 sheets.

-1993c, Properties and chemical constituents in ground water from permeable zone E (lower Miocene-upper Oligocene deposits), coastal lowlands aquifer system, south-central United States: U.S. Geological Survey Water-Resources Investigations Report 92-4103, scale 1:3,500,000, 5 sheets.

Pettijohn, R.A., Weiss, J.S., and Williamson, A.K., 1988, Distribution of dissolved-solids concentrations and temperature in ground water of the gulf coast aquifer systems, south-central United States: U.S. Geological Survey Water-Resources Investigations Report 88-4082, map, scale 1:3,500,000, 5 sheets.

Plebuch, R.O., and Hines, M.S., 1967, Water resources of Pulaski and Saline Counties, Arkansas: U.S. Geological Survey Water-Supply Paper $1839-B, 25 \mathrm{p}$.

Poole, J.L., 1961, Ground-water resources of East Carroll and West Carroll Parishes, Louisiana: Louisiana Department of Public Works, $174 \mathrm{p}$.

Prudic, D.E., 1991, Estimates of hydraulic conductivity from aquifertest analyses and specific-capacity data, Gulf Coast regional aquifer systems, south-central United States: U.S. Geological Survey Water-Resources Investigations Report 90-4121, $38 \mathrm{p}$.

Rasmussen, W.C., 1947, Geology and ground-water resources of Caldwell County, Texas: Texas Board of Water Engineers Report 27, $63 \mathrm{p}$.

Ratzlaff, K.W., 1982, Land-surface subsidence in the Texas coastal region: Texas Department of Water Resources Report 272, 26 p.

Reed, J.E., 1972, Analog simulation of water-level declines in the Sparta Sand, Mississippi Embayment: U.S. Geological Survey Hydrologic Investigations Atlas HA-434, scale 1:2,500,000, 1 sheet.

Reed, J.E., and Broom, M.E., 1979, Digital model of the Bayou Bartholomew alluvial aquifer-stream system, Arkansas: U.S. Geological Survey Open-File Report 79-685, 37 p. 
Reed, P.C., and McCain, J.F., 1971, Water availability map of Baldwin County, Alabama: Geological Survey of Alabama and State Oil and Gas Board Special Map 96, 55 p.

Rettman, P.L., 1984, Ground-water resources of Limestone County, Texas: U.S. Geological Survey Open-File Report 84-713, 92 p.

Rogers, J.E., 1983, Preconstruction and simulated postconstruction ground-water levels at urban centers in the Red River Navigation Project area, Louisiana: U.S. Geological Survey WaterResources Investigations Report 83-4154, 33 p.

Rollo, J.R., 1966, Ground-water resources of the Greater New Orleans area, Louisiana: Louisiana Department of Conservation, Louisiana Geological Survey, and Louisiana Department of Public Works Water-Resources Bulletin 9,69 p.

Rollo, J.R., 1969, Salt-water encroachment in aquifers of the Baton Rouge area, Louisiana: Louisiana Department of Conservation, Louisiana Geological Survey, and Louisiana Department of Public Works Water-Resources Bulletin 13, 45 p.

Ryder, P.D., 1988, Hydrogeology and predevelopment flow in the Texas gulf coast aquifer systems: U.S. Geological Survey WaterResources Investigations Report 87-4248, 109 p.

Ryder, P.D., and Ardis, A.F., in press, Hydrology of the Texas gulf coast aquifer systems: U.S. Geological Survey Professional Paper 1416-E.

Sayre, A.N., 1937, Geology and ground-water resources of Duval County, Texas: U.S. Geological Survey Water-Supply Paper 776, $116 \mathrm{p}$.

Shafer, G.H., 1970, Ground-water resources of Aransas County, Texas: Texas Water Development Board Report 124, 81 p.

Shepard, E.M., 1907, Underground waters of Missouri, their geology and utilization: U.S. Geological Survey Water-Supply Paper 195, $224 \mathrm{p}$.

Smith, E.A., 1907, The underground water resources of Alabama: Alabama Geological Survey Monograph 6, $388 \mathrm{p}$.

Spiers, C.A., and Dalsin, G.J., 1979, Water for municipal and industrial development in Hinds, Madison, and Rankin Counties, Mississippi: Mississippi Research and Development Center Bulletin, $78 \mathrm{p}$.

Stephenson, L.W., and Crider, A.F., 1916, Geology and ground waters of northeastern Arkansas, with a discussion of the Chemical character of the waters by R.B. Dole: U.S. Geological Survey WaterSupply Paper 399, 315 p.

Sumner, D.M., and Wasson, B.E., 1984a, Summary of results of an investigation to define the geohydrology and simulate the effects of large ground-water withdrawals on the Mississippi River alluvial aquifer in northwestern Mississippi: U.S. Geological Survey Water-Resources Investigations Report 84-4343, $17 \mathrm{p}$. 1984b, Geohydrology and simulated effects of large groundwater withdrawals on the Mississippi River alluvial aquifer in northwestern Mississippi: U.S. Geological Survey Open-File Report 84-822, 83 p.

Sun, R.J., ed., 1986, Regional Aquifer-System Analysis Program of the U.S. Geological Survey-Summary of projects, 1978-84: U.S. Geological Survey Circular 1002, 264 p.

Sun, R.J., and Weeks, J.B., 1991, Bibliography of Regional Aquifer-System Analysis program of the U.S. Geological Survey, 1978-91: U.S. Geological Survey Water-Resources Investigations Report 91-4122, 92 p.

Sundstrom, R.W., and Follett, C.R., 1950, Ground-water resources of Atascosa County, Texas: U.S. Geological Survey Water-Supply Paper 1079-C, p. 107-153.

Taylor, R.E., and Arthur, J.K., 1989, Hydrogeology of the middle Wilcox aquifer system in Mississippi: U.S. Geological Survey Water-Resources Investigations Report 89-4036, map, scale 1:500,000, 2 sheets.
Taylor, R.E., and Thomson, F.H., 1971, Water for industry and agriculture in Washington County, Mississippi: Delta Council Bulletin, $64 \mathrm{p}$.

Taylor, T.U., 1907, Underground waters of Coastal Plain of Texas: U.S. Geological Survey Water-Supply Paper 190, 73 p.

Terry, J.E., Hosman, R.L., and Bryant, C.T., 1979, Summary appraisals of the Nation's ground-water resources-Lower Mississippi region: U.S. Geological Survey Professional Paper 813-N, 41 p.

Theis, C.V., 1935, The relation between the lowering of the piezometric surface and the rate and duration of discharge of a well using ground-water storage: American Geophysical Union Transactions, v.[16], pt. 2, p. 519-524.

Tomaszewski, D.J., 1988, Ground-water hydrology of Livingston, St. Helena, and parts of Ascension and Tangipahoa Parishes, southeastern Louisiana: Louisiana Department of Transportation and Development Water Resources Technical Report 43, 65 p.

Torak, L.J., and Whiteman, C.D., Jr., 1982, Applications of digital modeling for evaluating the ground-water resources of the "2,000-foot" sand of the Baton Rouge area, Louisiana: Louisiana Department of Transportation and Development, Office of Public Works Water Resources Technical Report 27,87 p.

Toulmin, L.D., LaMoreaux, P.E., and Lamphere, C.R., 1951, Geology and ground-water resources of Choctaw County, Alabama: Geological Survey of Alabama and State Oil and Gas Board County Report 2, $197 \mathrm{p}$.

Trudeau, D.A., and Buono, Anthony, 1985, Projected effects of proposed increased pumpage on water levels and salinity in the Sparta aquifer near West Monroe, Louisiana: Louisiana Department of Transportation and Development Water Resources Technical Report 39, 70 p.

Turner, S.F., Robinson, T.W., and White, W.N., 1960, Geology and ground-water resources of the Winter Garden district, Texas, 1948: U.S. Geological Survey Water-Supply Paper 1481, 247 p.

U.S. Bureau of the Census, 1913, Abstract of the census: U.S. Department of Commerce, $569 \mathrm{p}$.

1922, Population, 1920, general report and analytical tables: U.S. Department of Commerce, v. 2, 1410 p.

1982a, 1980 Census of population, volume 1, chapter A, part 2, Alabama: U.S. Department of Commerce, $42 \mathrm{p}$.

1982b, 1980 Census of population, volume 1, chapter A, part 5, Arkansas: U.S. Department of Commerce, 43 p.

1982c, 1980 Census of population, volume 1, chapter A, part 11, Florida: U.S. Department of Commerce, $63 \mathrm{p}$.

1982d, 1980 Census of population, volume 1, chapter A, part 15, Illinois: U.S. Department of Commerce, 81 p.

1982e, 1980 Census of population, volume 1, chapter A, part 19, Kentucky: U.S. Department of Commerce, 45 p.

1982f, 1980 Census of population, volume 1, chapter A, part 20, Louisiana: U.S. Department of Commerce, $38 \mathrm{p}$.

$1982 \mathrm{~g}, 1980$ Census of population, volume 1, chapter A, part 26, Mississippi: U.S. Department of Commerce, 38 p. 1982h, 1980 Census of population, volume 1, chapter A, part 27, Missouri: U.S. Department of Commerce, $60 \mathrm{p}$.

1982i, 1980 Census of population, volume 1, chapter A, part 44, Tennessee: U.S. Department of Commerce, 45 p.

1982j, 1980 Census of population, volume 1, chapter A, part 45, Texas: U.S. Department of Commerce, 99 p.

U.S. Census Office, 1883, Statistics of the population of the United States at the tenth census: U.S. Department of the Interior, $375 \mathrm{p}$.

U.S. Geological Survey, [1951], Water, in West Carroll Parish resources and facilities: Louisiana Department of Public Works and West Carroll Parish Development Board, p. 39-44.

Veatch, A.C., 1906, Geology and underground water resources of northern Louisiana and southern Arkansas: U.S. Geological Survey Professional Paper 46, 422 p. 
Wasson, B.E., Golden, H.G., and Gaydos, M.W., 1965, Available water for industry-Clay, Lowndes, Monroe, and Oktibbeha Counties, Mississippi: Mississippi Research and Development Center Bulletin, $39 \mathrm{p}$.

Weiss, J.S., 1987, Determining dissolved-solids concentrations in mineralized ground water of the gulf coast aquifer systems, using electric logs, in Vecchioli, John, and Johnson, A.I, eds., Regional Aquifer Systems of the United States, Aquifers of the Atlantic and Gulf Coastal Plain: American Water Resources Association, Monograph no. 9, p. 139-150.

-1992, Geohydrologic units of the coastal lowlands aquifer system, south-central United States: U.S. Geological Survey Professional Paper 1416-C, $32 \mathrm{p}$.

Weiss, J.S., and Williamson, A.K., 1985, Subdivision of thick sedimentary units into layers for simulation of ground-water flow: Ground Water, v. 23, no. 6, p. 767-774.

Wells, F.G., 1932, A preliminary report on the artesian water supply of Memphis, Tennessee, in Grover, N.C., comp., Contributions to the hydrology of the United States: U.S. Geological Survey Water-Supply Paper 638-A, p. 1-34.

West, S.W., and Broadhurst, W.L., 1975, Summary appraisals of the Nation's ground-water resources-Rio Grande region: U.S. Geological Survey Professional Paper 813-D, 39 p.

White, W.N., Rose, N.A., and Guyton, W.F., 1944, Ground-water resources of the Houston District, Texas: U.S. Geological Survey Water-Supply Paper 889-C, p. 141-289.

Whiteman, C.D., Jr., 1979, Saltwater encroachment in the "600-foot" and "1,500-foot" sands of the Baton Rouge area, Louisiana, 196678 , including a discussion of saltwater in other sands: Louisiana Department of Transportation and Development, Office of Public Works Water-Resources Technical Report 19, 49 p.

Whiteman, C.D., Jr., 1980, Measuring local subsidence with extensometers in the Baton Rouge area, Louisiana, 1975-79: Louisiana Department of Transportation and Development, Office of Public Works Water-Resources Technical Report 20, 18 p.

Whiteman, C.D., Jr., and Martin, Angel, Jr., 1984, Geohydrologic sections, northern Louisiana: U.S. Geological Survey WaterResources Investigations Report 84-4211, 1 sheet.

Wilhelm, Oscar, and Ewing, Maurice, 1972, Geology and history of the Gulf of Mexico: Geological Society of America Bulletin, v. 83, no. 3 , p. 575-600.
Williams, T.A., and Williamson, A.K., 1989, Estimating water-table altitudes for regional ground-water flow modeling, U.S. Gulf Coast: Ground Water, v. 27, no. 3, p. 333-340.

Williamson, A.K., 1987, Preliminary simulation of ground-water flow in the gulf coast aquifer systems, south-central United States, in Vecchioli, John, and Johnson, A.I., eds., Regional Aquifer Systems of the United States, Aquifers of the Atlantic and Gulf Coastal Plain: American Water Resources Association, Monograph no. 9, p. 119-137.

Williamson, A.K., and Grubb, H.F., in press, Ground-water flow in the gulf coast aquifer systems, south-central United States: U.S. Geological Survey Professional Paper 1416-F.

Williamson, A.K., Grubb, H.F., and Weiss, J.S., 1990, Ground-water flow in the Gulf Coast aquifer systems, south-central United States-A preliminary analysis: U.S. Geological Survey WaterResources Investigations Report 89-4071, $124 \mathrm{p}$.

Wilson, J.M., and Criner, J.H., 1969, Geohydrology of Henry and Weakley Counties: Tennessee Department of Conservation, Division of Water Resources Series 7, $49 \mathrm{p}$.

Wilson, T.A., and Hosman, R.L., 1988, Geophysical well-log database for the gulf coast aquifer systems, south-central United States: U.S. Geological Survey Open-File Report 87-677, 213 p.

Winslow, A.G., 1950, Geology and ground-water resources of Walker County, Texas: Texas Board of Water Engineers Bulletin $5003,52 \mathrm{p}$.

Winslow, A.G., and Doyel, W.W., 1954, Land-surface subsidence and its relation to the withdrawal of ground water in the HoustonGalveston region, Texas: Economic Geology, v. 49, no. 4, p. 413422.

Winslow, A.G., Doyel, W.W., and Wood, L.A., 1957, Salt water and its relation to fresh ground water in Harris County, Texas: U.S. Geological Survey Water-Supply Paper 1360-F, p. 375-407.

Winslow, A.G., and Wood, L.A., 1959, Relation of land subsidence to ground-water withdrawals in the upper Gulf Coast region, Texas: Mining Engineer, v. 11, no. 10, p. 1030-1034.

Wood, L.A., and Gabrysch, R.K., 1965, Analog model study of ground water in the Houston District, Texas, with a section on Design, construction, and use of electric analog models, by E.P. Patten, Jr.: Texas Water Commission Bulletin 6508, 103 p.

Zurawski, Ann, 1978, Summary appraisals of the Nation's groundwater resources-Tennessee region: U.S. Geological Survey Professional Paper 813-L, 35 p. 





\section{Selected Series of U.S. Geological Survey Publications}

\section{Books and Other Publications}

Professional Papers report scientific data and interpretations of lasting scientific interest that cover all facets of USGS investigations and research.

Bulletins contain significant data and interpretations that are of lasting scientific interest but are generally more limited in scope or geographic coverage than Professional Papers.

Water-Supply Papers are comprehensive reports that present significant interpretive results of hydrologic investigations of wide interest to professional geologists, hydrologists, and engineers. The series covers investigations in all phases of hydrology, including hydrogeology, availability of water, quality of water. and use of water.

Circulars are reports of programmatic or scientific information of an ephemeral nature; many present important scientific information of wide popular interest. Circulars are distributed at no cost to the public.

Fact Sheets communicate a wide variety of timely information on USGS programs, projects, and research. They commonly address issues of public interest. Fact Sheets generally are two or four pages long and are distributed at no cost to the public.

Reports in the Digital Data Series (DDS) distribute large amounts of data through digital media. including compact discread-only memory (CD-ROM). They are high-quality, interpretive publications designed as self-contained packages for viewing and interpreting data and typically contain data sets. software to view the data, and explanatory text.

Water-Resources Investigations Reports are papers of an interpretive nature made available to the public outside the formal USGS publications series. Copies are produced on request (unlike formal USGS publications) and are also available for public inspection at depositories indicated in USGS catalogs.

Open-File Reports can consist of basic data, preliminary reports, and a wide range of scientific documents on USGS investigations. Open-File Reports are designed for fast release and are available for public consultation at depositories.

\section{Maps}

Geologic Quadrangle Maps (GQ's) are multicolor geologic maps on topographic bases in 7.5- or 15-minute quadrangle formats (scales mainly 1:24,(000 or 1:62,500) showing bedrock. surficial, or engineering geology. Maps generally include brief texts: some maps include structure and columnar sections only.

Geophysical Investigations Maps (GP's) are on topographic or planimetric bases at various scales. They show results of geophysical investigations using gravity, magnetic, seismic, or radioactivity surveys, which provide data on subsurface structures that are of economic or geologic significance.
Miscellaneous Investigations Series Maps or Geologic Investigations Series (I's) are on planimetric or topographic bases at various scales: they present a wide variety of format and subject matter. The series also incudes 7.5-minute quadrangle photogeologic maps on planimetric bases and planetary maps.

\section{Information Periodicals}

Metal Industry Indicators (MII's) is a free monthly newsletter that analyzes and forecasts the economic health of five metal industries with composite leading and coincident indexes: primary metals, steel, copper, primary and secondary aluminum, and aluminum mill products.

Mineral Industry Surveys (MIS's) are free periodic statistical and economic reports designed to provide timely statistical data on production. distribution. stocks, and consumption of significant mineral commodities. The surveys are issued monthly, quarterly, annually, or at other regular intervals, depending on the need for current data. The MIS's are published by commodity as well as by State. A series of international MIS's is also available.

Published on an annual basis. Mineral Commodity Summaries is the earliest Government publication to furnish estimates covering nonfuel mineral industry data. Data sheets contain information on the domestic industry structure. Government programs, tariffs, and 5-year salient statistics for more than 90 individual minerals and materials.

The Minerals Yearbook discusses the performance of the worldwide minerals and materials industry during a calendar year, and it provides background information to assist in interpreting that performance. The Minerals Yearbook consists of three volumes. Volume I, Metals and Minerals, contains chapters about virtually all metallic and industrial mineral commodities important to the U.S. economy. Volume II, Area Reports: Domestic, contains a chapter on the minerals industry of each of the 50 States and Puerto Rico and the Administered Islands. Volume III, Area Reports: International, is published as four separate reports. These reports collectively contain the latest available mineral data on more than 190 foreign countries and discuss the importance of minerals to the economies of these nations and the United States.

\section{Permanent Catalogs}

"Publications of the U.S. Geological Survey, 1879-1961" and "Publications of the U.S. Geological Survey, 19621970 " are available in paperback book form and as a set of microfiche.

"Publications of the U.S. Geological Survey, 1971-1981" is available in paperback book form (two volumes, publications listing and index) and as a set of microfiche.

Annual supplements for 1982. 1983, 1984, 1985, 1986, and subsequent years are available in paperback book form. 